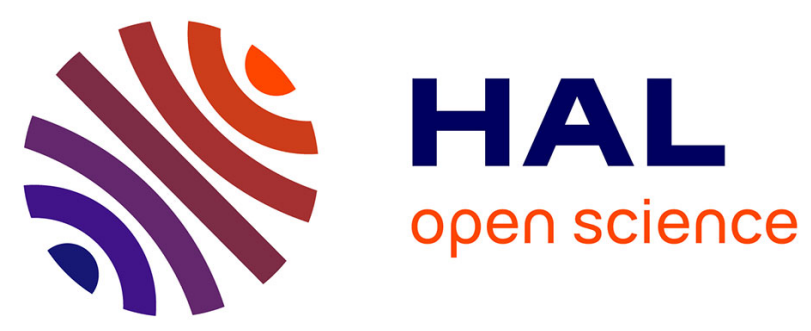

\title{
Mitogenomic phylogeny of mud snails of the mostly Atlantic/ Mediterranean genus Tritia (Gastropoda: Nassariidae)
}

Yi Yang, Samuel Abalde, Carlos Afonso, Manuel J Tenorio, Nicolas Puillandre, Jose Templado, Rafael Zardoya

\section{To cite this version:}

Yi Yang, Samuel Abalde, Carlos Afonso, Manuel J Tenorio, Nicolas Puillandre, et al.. Mitogenomic phylogeny of mud snails of the mostly Atlantic/ Mediterranean genus Tritia (Gastropoda: Nassariidae). Zoologica Scripta, inPress. hal-03172830

\section{HAL Id: hal-03172830 \\ https://hal.science/hal-03172830}

Submitted on 19 Mar 2021

HAL is a multi-disciplinary open access archive for the deposit and dissemination of scientific research documents, whether they are published or not. The documents may come from teaching and research institutions in France or abroad, or from public or private research centers.
L'archive ouverte pluridisciplinaire HAL, est destinée au dépôt et à la diffusion de documents scientifiques de niveau recherche, publiés ou non, émanant des établissements d'enseignement et de recherche français ou étrangers, des laboratoires publics ou privés. 

genus Tritia (Gastropoda: Nassariidae)

9

*Corresponding author (rafaz@mncn.csic.es)

${ }^{2}$ Centre of Marine Sciences (CCMAR), Universidade do Algarve, Campus de Gambelas, 8005-139 Faro, Portugal

${ }^{3}$ Departamento CMIM y Q. Inorgánica-INBIO, Facultad de Ciencias, Universidad de Cadiz; 11510 Puerto Real, Cádiz, Spain;

${ }^{4}$ Institut de Systématique, Évolution, Biodiversité (ISYEB), Muséum National d’Histoire Naturelle, CNRS, Sorbonne Université, EPHE, Université des Antilles, 57 rue Cuvier, CP 26, 75005 Paris, France. 


\section{Abstract}

The mud snails endemic to the East Atlantic/Mediterranean region (genus Tritia; subfamily Nassariinae) account for the second highest diversity within the family Nassariidae (Gastropoda: Buccinoidea). In order to understand how the diversity of species, shell morphologies, and ecological traits evolved within this genus, a robust phylogenetic framework is needed, yet still unavailable due to high levels of homoplasy in shell morphology, the main trait used for their taxonomic classification. Here, the near-complete mitogenomes of 20 species representing more than half of the diversity of Tritia were sequenced. All mitogenomes of Tritia shared the same gene order, which is identical to the consensus reported for caenogastropods. The reconstructed phylogeny indicates that all analyzed Tritia species formed a natural group except Tritia vaucheri, which was sister to an early diverging clade within subfamily Nassariinae that includes species of genus Reticunassa sister to Nassarius jacksonianus and Nassarius sp. Within Tritia, the Northwest Atlantic species Tritia obsoleta was placed as the sister group of three mostly East Atlantic/Mediterranean clades (I-III), prompting the reinstatement of the genus Ilyanassa. The latter three clades corresponded to different shell features (I, shell mostly with marked sculpture; II, shell with strong nodules and small size; and III, smooth shell). For Tritia incrassata, the analyzed specimens from Norway and from the Spanish Mediterranean coasts showed notable genetic divergence, which may indicate the existence of cryptic species. The ancestral character state reconstruction of protoconch inferred that the ancestor of Tritia had planktotrophic larvae, and that a transition to lecithotrophy occurred independently at least three times within Nassariinae. The reconstructed chronogram dated the origin of Tritia in the Oligocene and main diversification events during the Miocene to Pleistocene, correlated with drastic shifts in local paleoecosystems caused by cooling events, eustatic sea level changes, and the Messinian Salinity Crisis that favored temperate taxa.

\section{KEYWORDS}

Nassariinae, Tritia, Ilyanassa, mitochondrial genome, phylogeny, chronogram 


\section{INTRODUCTION}

Mud snails or dog whelks (family Nassariidae) are small- to medium-sized snails, readily recognized by their fusiform, slender to broadly ovate shells of moderately sculptured surface (from smooth to cancellate or reticulate) with more or less prominent axial and spiral ribs and cords (Cernohorsky, 1984). The base of the shell aperture has a notch for extension of their long siphon. The columella is short with a pronounced siphonal fold (Cossmann, 1901). The reduced operculum is thin and corneous with a terminal nucleus and often marginally serrated. Most nassariids species are facultative scavengers or non-selective predators (Morton, 2011). Their characteristic long inhalant siphon (as long as their body) together with a well-developed osphradium allows acute chemoreception and efficiently leads to carrion or prey. Their often very wide and flattened foot enables these sea snails to glide quickly and easily over soft substrata.

The nassariids constitute an important component of the biodiversity of tropical and temperate seas and attain their greatest diversity in the tropical Indo-Pacific (Cernohorsky, 1984). A few species have reached the polar seas (Nekhaev, 2014). Mud snails inhabit predominantly in shallow water soft bottoms, but some live in deep water, and many characterize certain types of sediments where they are dominant (Harasewych, 1998; Hayashi, 2004). For instance, the species of the genus Bullia are the most conspicuous surfing organisms of the swash zone of many sandy beaches in the southern hemisphere, and some species of Nassarius and Tritia display dense populations in estuaries and coastal lagoons. Several species have adapted to brackish water and a few have successfully conquered freshwater habitats in Southeast Asia (Strong, Galindo, \& Kantor, 2017). Due to their abundance, nassariids have been well studied from different points of view. For instance, many nassarid species are known to accumulate toxins and as such constitute a health problem especially in Asia (Hwang et al., 2005); other species have been used as model organisms, such as Tritia obsoleta (as Ilyanassa obsoleta) in developmental biology (Goulding \& Lindberg, 2016) or Bullia digitata in ecological and behavioral studies (Brown, 1980). Furthermore, nassariids have a rich fossil record (Gili \& Martinell, 1993, Tracey, Todd, \& Erwin, 1993; Haasl, 2000; Harzhauser \& Kowalke, 2004; Landau, da Silva, \& Gili, 2009) since the lower Cretaceous (Taylor, Morris, \& Taylor, 1980) that should help understanding major evolutionary trends within the family when interpreted within a phylogenetic framework.

The first thorough classification of nassariids was based on the shape of the shell columella (Cossmann, 1901), and is still in use with slight modifications (Cernohorsky, 1984). The family was traditionally divided into three subfamilies: Nassarinae, Dorsaniinae and Cylleninae, until Allmon (1990) transferred several genera previously included in Dorsaniinae to establish the new subfamily Bulliinae. However, the taxonomy of these subfamilies, especially the status of genera and 
subgenera, has remained far from resolved because of rampant convergence in shell morphology and other phenotypic characters due to adaptations to similar environmental or selective pressures. Moreover, most nassariids species were assigned by default to the genus Nassarius and many are still provisionally included in this genus, which demands thorough revision.

Recently, a molecular phylogeny including more than 200 putative nassariid species was reconstructed based on partial sequences of five (mitochondrial and nuclear) genes (Galindo et al., 2016). This molecular phylogeny showed that the morphology-based taxonomy of the family (Cernohorsky, 1984; Allmon, 1990; Haasl, 2000; Kantor, 2003) was dominated by homoplasy and had little phylogenetic significance. Genera were redefined, the new subfamily Buccinanopsinae was created, and the taxon Photinae was reestablished at subfamily level (Galindo et al., 2016).

The reconstructed phylogeny of Galindo et al. (2016) showed that the cosmopolitan subfamily Nassariinae comprises about 80\% of nassariid species diversity (MolluscaBase, 2020a). Up to five strongly supported clades were recovered within this subfamily and were assigned to genera with relatively distinct geographical distributions: the Indo-Pacific Nassarius and Reticunassa (the “pauper-complex” sensu Kool \& Dekker, 2006, 2007, Galindo, Kool, \& Dekker, 2017); the mostly Atlantic-Mediterranean Tritia; the (East and West) African Naytia; and the Caribbean-Panamanian Phrontis. Furthermore, these genera showed different types of protoconch. The multispiral protoconchs of species assigned to Nassarius and Reticunassa have one or two keels, whereas those of species included within Tritia, Naytia, and Phrontis lack a keel (Galindo et al., 2016). Transitions to a paucispiral protoconch have occurred independently within different genera (Galindo et al., 2016).

Phylogenetic relationships among species within the different genera remained largely unresolved in several cases (Galindo et al., 2016). After Galindo et al. (2016) around 60 species were reclassified into genera other than Nassarius but more than 300 species remained tentatively in this genus (MolluscaBase, 2020b) awaiting further phylogenetic studies. In this regard, two subsequent mitogenomic studies that focused on the genus Nassarius improved the resolution of phylogenetic relationships among species restricted to the China seas (Yang, Li, Kong, \& Yu, 2019; Yang et al., 2020), compared with previous attempts based on partial gene sequences (e.g., Zhang \& You, 2009; Chen \& Zhang, 2012; Pu et al., 2017). As a result of these mitogenomic studies, the composition of the genus Nassarius was refined, with Nassarius jacksonianus and Nassarius sp. (incorrectly identified as N. acuticostus; see Supporting Information Figure S1) placed with strong statistical support as sister to Reticunassa (Yang, Li, Kong, \& Yu, 2019). Furthermore, another mitogenomic phylogenetic study focused on genus Reticunassa revealed cryptic species (Yang, Li, Kong, \& Yu, 2018). These studies highlight the need of studying in depth the species composition 
and phylogenetic relationships within the five recognized Nassariinae genera. They also confirm the high levels of resolution achieved by complete mitochondrial genomes when inferring phylogenetic relationships of gastropods below the family level (Uribe, Puillandre, \& Zardoya, 2017).

The traditional taxonomy of the Atlantic/Mediterranean nassariids was mainly based on shell characters, with species classified into different genera (Hinia, Nassarius, Sphaeronassa, Naytiopsis, Cyclope and Ilyanassa). Even though species of Cyclope possess rather unique flattened shell geometry, and Ilyanassa is restricted to the Northwest Atlantic, the molecular phylogeny of Nassariidae found no evidence to support these genera, which were both synonymized with Tritia (Galindo et al., 2016). At present, a total of 40 species are considered valid within Tritia (MolluscaBase, 2020c), including four species endemic to the Gulf of Gabès that were recently recognized as valid (Aissaoui, Galindo, Puillandre, \& Bouchet, 2017). Several Tritia species extend their range distribution to West African coasts living in sympatry with Naytia species.

In order to clarify the taxonomy of the genus Tritia in the Atlantic/ Mediterranean region, a robust phylogeny of the group is needed. Thus far, only two complete mitochondrial genomes of Tritia species are available i.e., T. obsoleta (DQ238598; Simison, Lindberg, \& Boore, 2006, as Ilyanassa obsoleta) and T. reticulata (EU827201; Cunha, Grande, \& Zardoya, 2009). In the present study, we sequenced the nearly complete (without the control region or partial gene sequences) mitochondrial genomes of 21 specimens representing 20 species of Tritia (i.e., half of the diversity of the genus) and of one specimen of the freshwater nassariid Anentome sp. as outgroup. Our aims were: (1) to test the monophyly of the genus Tritia as currently defined (MolluscaBase, 2020c); (2) to reconstruct robust phylogenetic relationships within the genus; (3) to date the origin and main cladogenetic events during the diversification of this genus; and (4) to test the validity of shell morphology in Tritia taxonomy.

\section{MATERIALS AND METHODS}

\subsection{Samples and DNA extraction}

The complete list of specimens analyzed in the present study, including their sampling sites, collectors, and museum vouchers is shown in Table 1 . Samples were stored in $100 \%$ ethanol at $4^{\circ} \mathrm{C}$ or $-20^{\circ} \mathrm{C}$, and total genomic DNA was isolated from foot muscle using the DNeasy Blood \& Tissue Kit (Qiagen, Germany).

\subsection{PCR amplification and sequencing}


Nearly complete (without the control region or partial gene sequences) mt genomes were amplified in two main steps. First, fragments of $\operatorname{cox} 1$, cox3, $r r n S$, $r r n L$, and $c o b$ genes were amplified through standard PCRs, which were carried out in a total volume of $25 \mu$ l with $1 \mu$ l of template DNA (25-40 $\mathrm{ng} / \mu \mathrm{l}), 2.5 \mu \mathrm{l}$ of $10 \times$ buffer $\left(\mathrm{Mg}^{2+}\right.$ plus), $0.5 \mu \mathrm{l}$ of dNTPs $(2.5 \mathrm{mM}), 0.5 \mu \mathrm{l}$ of each primers $(10 \mu \mathrm{M})$, $0.2 \mu \mathrm{l}$ of Taq DNA polymerase (5 U/ $\mu \mathrm{l}), 0.25 \mu \mathrm{l}$ of BSA $(10 \mathrm{mg} / \mathrm{ml})$ and $19.55 \mu \mathrm{l}$ of DEPC water. The PCR conditions were as follows: an initial denaturing step at $94{ }^{\circ} \mathrm{C}$ for $5 \mathrm{~min}$; 40 cycles of denaturing at $94{ }^{\circ} \mathrm{C}$ for $60 \mathrm{~s}$, annealing at $39-48^{\circ} \mathrm{C}$ for $60 \mathrm{~s}$, and extension at $72{ }^{\circ} \mathrm{C}$ for $90 \mathrm{~s}$; and a final extension step at $72{ }^{\circ} \mathrm{C}$ for $10 \mathrm{~min}$. Standard-PCR products were purified by ethanol precipitation, and Sanger sequenced at Macrogen (Seoul, Korea). Information on standard PCR primers is shown in Supporting Information Table S1.

In the second step, the obtained sequences were used to design specific primer pairs for long PCR amplification of the remaining mitogenome in four fragments (see Supporting Information Table S1). The long PCR reactions contained $2.5 \mu$ l of $10 \times$ buffer $\left(\mathrm{Mg}^{2+}\right.$ plus), $3 \mu \mathrm{l}$ of dNTPs (2.5 $\mathrm{mM}), 0.5 \mu \mathrm{l}$ of each primers $(10 \mu \mathrm{M}), 0.8 \mu \mathrm{l}$ of template DNA (25-40 ng/ $\mathrm{ll}), 0.2 \mu \mathrm{l}$ of TaKaRa LA Taq DNA polymerase ( $5 \mathrm{U} / \mu \mathrm{l}), 0.2 \mu \mathrm{l}$ of BSA $(10 \mathrm{mg} / \mathrm{ml})$ and DEPC water up to $25 \mu \mathrm{l}$. The following PCR conditions were used: initial denaturing step at $94{ }^{\circ} \mathrm{C}$ for $60 \mathrm{~s} ; 45$ cycles of denaturing at $98{ }^{\circ} \mathrm{C}$ for $10 \mathrm{~s}$, annealing at $53-56{ }^{\circ} \mathrm{C}$ for $30 \mathrm{~s}$, and extension at $68^{\circ} \mathrm{C}$ for $60 \mathrm{~s}$ per kb; final extension step at $68{ }^{\circ} \mathrm{C}$ for $10 \mathrm{~min}$. Long PCR products were purified by ethanol precipitation, and fragments from the same mitogenome were pooled together in equimolar concentrations for high-throughput sequencing. For each mitogenome of Tritia, a separate indexed library was constructed using the NEXTERA XT DNA library prep Kit (Illumina, San Diego, CA, USA) and run in an Illumina MiSeq platform (2 × 150 paired-end) at AllGenetics (A Coruña, Spain) and NIMGenetics (Madrid, Spain). Among the 20 libraries, five contained also the mitogenomes of cones or buccinoids from different projects (see Supporting Information Table S1).

Due to the degraded condition of the source DNA of T. ovoidea and T. tingitana, the partial mt genomes of these species were mostly amplified through standard PCRs, as only few long PCRs worked (see Supporting Information Table S1). Those amplified fragments with sizes $\leq 1,000$ bp were directly Sanger sequenced with the corresponding PCR primers, whereas the longer PCR products were Sanger sequenced using a primer walking strategy. Sequencing was performed in automated sequencers (ABI PRISM 3700) using the BigDye ${ }^{\circledR}$ Terminator v3.1 cycle-sequencing kit 
(Applied Biosystems, Foster City, CA, USA), and following the manufacturer's instructions.

For some species with tentative identification, namely $N$. jacksonianus and $N$. acusticostus, or of unexpected phylogenetic position, namely T. ephamilla and T. vaucheri, the barcoding cox1 fragment was PCR amplified and Sanger sequenced to double check species identity (see Supporting Information Figure S1).

\subsection{Genome assembly and annotation}

The Sanger sequences were assembled using Sequencher 5.0.1. For the specimens from the MNHN collections, some cox1 sequences were downloaded from Genbank (see Supporting Information Table S1). For Illumina sequence data, the reads corresponding to different individuals were sorted by the corresponding library indices. Raw sequences were analyzed for quality control using FastQC v.0.11.9 (Andrews, 2010), and trimmed and filtered out according to their quality scores using PRINSEQ v.0.20.4 (Schmieder \& Edwards, 2011). Assembly of the mitogenomes was performed using Geneious Prime 2019.0.3 (Kearse et al., 2012). The mitogenomes were constructed by repeatedly mapping the original reads (setting a minimum identity of 99\%) to the Sanger fragments from the same mitogenome.

The newly determined mt genomes were annotated with Geneious Prime 2019.0.3. Annotations of protein-coding genes (PCGs) were defined by setting a limit of 75\% nucleotide identity to previously published nassariid mitogenomes (Table 1) in Geneious Prime 2019.0.3, and corroborated using the MITOS Webserver (Bernt et al., 2013) with the invertebrate mitochondrial genetic code. The transfer RNA (tRNA) genes were further identified using tRNA scan-SE 1.21 (Schattner, Brooks, \& Lowe, 2005) and ARWEN (Laslett \& Canbäck, 2008). The ribosomal RNA (rRNA) genes were first identified using the MITOS Webserver (Bernt et al., 2013). The software rendered shorter rRNA genes (due to sequence variability in the ends), and their boundaries were assumed to be between the adjacent genes by comparison with other nassariid mt genomes.

\subsection{Sequence alignment}

The newly sequenced mitogenomes were aligned along with those of other nassariids available in Genbank (Table 1). Representatives of different genera of Nassariinae were included in the ingroup to test the monophyly of Tritia. The freshwater nassariid Anentome sp. (subfamily Anentominae) 
was used as outgroup to root the tree (Galindo et al., 2016). A dataset concatenating the nucleotide sequences of the 13 PCGs and two rRNA genes was constructed and analyzed.

The 13 PCGs were aligned separately guided by amino acid translations (according to the invertebrate mitochondrial genetic code) using Translator X (Abascal, Zardoya, \& Telford, 2010), . Nucleotide sequences of the two rRNA genes were aligned separately using MAFFT v7 (Katoh \& Standley, 2013) with default parameters. Ambiguously aligned positions were removed using Gblocks v.0.91b (Castresana, 2000) with the following settings: minimum sequence for flanking positions: 85\%; maximum contiguous non-conserved positions: 8; minimum block length: 10; gaps in final blocks: no. Finally, the different single alignments were concatenated into a single data set in Geneious Prime 2019.0.3. Sequences were converted into different formats for downstream analyses using DAMBE5 (Xia, 2013).

\subsection{Phylogenetic analyses}

Pairwise uncorrected $p$ sequence distances to delimit species were estimated based on the alignment including the nucleotide sequences of the 13 PCGs and the two rRNA genes. Phylogenetic trees were reconstructed using maximum likelihood (ML; Felsenstein, 1981) and Bayesian inference (BI; Huelsenbeck \& Ronquist, 2001). ML analyses were carried out using IQtree 1.6.10 (Nguyen, Schmidt, Von Haeseler, \& Minh, 2015) in the CIPRES gateway (Miller, Pfeiffer, \& Schwartz, 2010), allowing partitions to have different evolutionary rates (-spp option) and with 10,000 ultrafast bootstrap pseudoreplications (-bb option). BI analyses were performed with MrBayes v.3.1.2 (Ronquist \& Huelsenbeck, 2003), running four simultaneous Monte Carlo Markov chains (MCMC) for 10,000,000 generations, sampling every 1000 generations, and discarding the first 25\% generations as burn-in. Two independent runs were performed to increase the chance of adequate mixing of the Markov chains and to increase the chance of detecting failure to converge, as determined by using Tracer v1.6. The effective sample size (ESS) of all parameters was higher than 200. The resulting phylogenetic trees were visualized in FigTree v1.4.2.

The best partition schemes and best-fit substitution models for BI analysis of the data set were determined (see Supporting Information Table S2 for selected best fit partitions and models) using PartitionFinder 2 (Lanfear et al., 2017), under the Bayesian Information Criterion (BIC; Schwarz, 1978). For the 13 PCGs, the partitions tested were: all genes combined; all genes separated (except 
atp6-atp8 and nad4-nad4L); and genes grouped by subunits (atp, cob, cox and nad). Additionally, these three partition schemes were tested considering separately the three codon positions. The two rRNA genes were analyzed with two different schemes (genes grouped or separated). The best-fit substitution models for ML analysis were calculated with ModelFinder (Kalyaanamoorthy, Minh, Wong, Haeseler, \& Jermiin, 2017) as implemented in IQ-TREE 1.6.10.

\subsection{Ancestral Character State Reconstruction}

The type of larval shell or protoconch with a single (paucispiral) or multiple whorls (multispiral) was accessed based on literature (Galindo et al., 2016; Aissaoui, Galindo, Puillandre, \& Bouchet, 2017) except for T. vaucheri, which was determined by direct examination of the shells (the number of whorls was counted to the nearest quarter whorl; Modica et al., 2020). Both types of protoconch were used as a proxy of the lecithotrophic (direct development using yolk reserves) or planktotrophic (with a feeding veliger phase) modes of larval development (Strathmann, 1978). The evolution of larval development was analyzed by performing an ancestral character state reconstruction in Mesquite v3.6.1 (Maddison \& Maddison, 2018) using the Tracing Character History option under ML and mapping onto the identical topology inferred by the ML and BI analyses.

\subsection{Estimation of divergence times}

The program BEAST v.1.10.4 (Drummond \& Rambaut, 2007) was used to perform a Bayesian estimation of divergence times among main nassariid lineages based on PCGs only. An uncorrelated relaxed molecular clock was used to infer branch lengths and node ages. The tree topology was fixed using the identical topology recovered by the ML and BI analyses. For the clock model, the lognormal relaxed-clock model was selected, which allows rates to vary among branches without any a priori assumption of autocorrelation between adjacent branches. For the tree prior, a Yule process of speciation was employed. The partitions selected by PartitionFinder 2 (see above) were applied. The final Markov chain was run twice for 100 million generations, sampling every 10,000 generations and the first 10 million were discarded as burn-in, according to the convergence of chains checked with Tracer v.1.6. The effective sample size of all the parameters was above 200. 
calibration points based on fossil data as priors for divergence times of the corresponding splits. The prior distributions of the three calibration nodes were selected following Ho \& Phillips (2009). For the origin of the lineage leading to T. neritea and T. pellucida, a calibration point was set at the minimum limit of 3.6 million years ago (Mya; exponential distribution, offset: 3.6; mean: 1.0) based on the fossils of Cyclope migliorinii that are the oldest for the stem group (Gili \& Martinell, 1999; Landau, da Silva, \& Grigis, 2009) and dated from the Pliocene (Placenzian; 3.6 - 2.6 Mya) of Spain according to the Paleobiology Database (https://paleobiodb.org). A second calibration point was set at the origin of Tritia. A lognormal distribution was applied, with the minimum of 23 Mya and a 95\% upper limit of 28.4 Mya (offset: 23; mean: 1.9; standard deviation: 1.9) based on Nassarius (Hinia) pygmaea from Germany (Albright et al., 2019) and Nassarius (Hinia) schlotheimi from Hungary (Báldi, 1973), both from the Oligocene (Chattian; 28.4 - 23.0 Mya), the oldest Nassariinae fossils in Europe (Lozouet, 1999). A third calibration point was set at the root of the tree. A lognormal distribution was applied, with the minimum of 55.8 Mya and a 95\% upper limit of 58.7 Mya (offset: 55.8; mean: 1.0; standard deviation: 1.0) based on the oldest known Nassariinae fossil, which is Buccitriton sagenum from the Paleocene (Thanetian; 58.7 - 55.8 Mya) of Lousiana, USA (Glawe, Anderson, \& Bell, 2014).

\section{RESULTS}

\subsection{Sequencing and assembly}

All newly sequenced mt genomes in the present study lacked the sequences of the trnF gene, the control region, and the start of the cox3 gene because the corresponding fragment could not be PCR amplified. The number of reads, mean coverage, length, and accession number in Genbank of each mitogenome are provided in Table 1 . The $\mathrm{mt}$ genomes of $T$. incrassata-SP and $T$. varicosa received the minimum (53x; 30,800 reads) and maximum (23,350x; 2,765,768 reads) coverage, respectively (Table 1).

\subsection{Genome organization}

The newly determined Tritia mitogenomes encode for 13 PCGs, two rRNA and 22 tRNA genes (but note that the trnF gene could not be determined in all mt genomes; see annotation of each mt genome in Supporting Information Table S3). They all share the same genome organization 
described for Caenogastropoda (Osca, Templado, \& Zardoya, 2015), with most genes encoded by the major strand and a cluster of tRNA genes (trnM, $\operatorname{trn} Y, \operatorname{trn} C, \operatorname{trn} W, \operatorname{trn} Q, \operatorname{trn} G, \operatorname{trn} E)$ and the trnT gene encoded by the minor strand (Figure 1). All PCGs start with the conventional initiation codon ATG (but note that the start of the cox3 gene could not be determined in all $\mathrm{mt}$ genomes; see Supporting Information Table S3). As for the termination codons, two genes (cox2 and atp8) consistently ended with TAA and two (nad4L and nad5) stopped with TAG. The incomplete stop codon (TA-), which becomes functional after polyadenylation (Ojala et al., 1981), was observed in all nad2 genes but that of Tritia grana, which ended with TAA. The remaining genes varied in their stop codons depending on the species (Supporting Information Table S3).

\subsection{Phylogenetic relationships}

Phylogenetic relationships of Tritia were reconstructed based on the nucleotide sequences of the concatenated 13 PCGs and two rRNA genes using probabilistic methods (Figure 2). The final matrix was 13,101 positions in length. According to the BIC, the best partition scheme for the PCGs was the one combining genes by subunits but analyzing each codon position separately (Supporting Information Table S2). For the rRNA genes, the best partition scheme was the one combining together $r r n L$ and $r r n S$ genes. Both $\mathrm{ML}(-\ln L=133,593.77)$ and $\mathrm{BI}(-\ln L=133,905.39$ for run 1; $-\ln L=133,908.66$ for run 2) analyses arrived at identical topologies (Figure 2).

According to the reconstructed phylogeny, $N$. jascksonianus and Nassarius sp were recovered closer to Reticunassa than to other Nassarius species (Figure 2). Tritia vaucheri was placed sister to the clade including (N. jascksonianus and Nassarius sp.) + Reticunassa, and apart from the remaining Tritia species, which formed a natural group. Within this latter group, the Northwest Atlantic species T. obsoleta was placed as sister to three mostly Northeast Atlantic/ Mediterranean clades (I-III). Clade I included ten species distributed into five lineages: (1) T. ephamilla (endemic to New Zealand and southern Australia) and T. ovoidea + T. elata, (2) T. denticulata, (3) T. tingitana, (4) T. reticulata and T. nitida, and (5) the "T. cuvierii complex" including T. unifasciata and T. cuvierii + T. tenuicosta. This clade was sister to clades II and III (Figure 2). Clade II comprised T. varicosa and T. incrassata (including one specimen from a Spanish Mediterranean population and one from Norway). Clade III included T. elongata + (T. pallaryana and T. corniculum) sister to a group formed by T. grana + (T. neritea and T. pellucida) and T. pfeifferi + T. mutabilis (Figure 2). 


\subsection{Ancestral character state reconstruction}

The ancestral character state reconstruction analysis inferred that the Atlantic/Mediterranean nassariids could have originated from an ancestor with a multispiral protoconch, which indicates a planktotrophic mode of larval development (Figure 3). The “T. cuvierii complex”, clade III, and T. tingitana were inferred to represent independent evolutionary transitions to a paucispiral protoconch, suggesting a secondary loss of the planktotrophic mode of larval development to lecitotrophy.

\subsection{Divergence times}

Main cladogenetic events within Tritia were dated using an uncorrelated relaxed molecular clock model, which was calibrated using three Atlantic fossils. The origin of the stem lineage leading to genus Tritia (including T. obsoleta and without T. vaucheri) was dated 24.0 (26.2-23.1, 95\% highest posterior density interval, HPD) million years ago (Mya). The first event of diversification within the crown group of Tritia was estimated at a mean of 20.4 (23.5-17.1) Mya, separating the Northwest Atlantic T. obsoleta from T. ephamilla and East Atlantic/ Mediterranean Tritia species. The branching of the three main East Atlantic/ Mediterranean clades was estimated to have occurred around 18.9-17.6 (22.0-14.4) Mya. Finally, main diversification events leading to extant Tritia species were estimated to have occurred between 16.9-3.9 (20.1-2.0) Mya, whereas divergences of some closely-related species or populations were dated about 0.6-0.1 Mya (Figure 4).

\section{DISCUSSION}

\subsection{Taxonomy of the non-Tritia Nassariinae}

The often-ornamented shell of nassariids, which could in principle provide numerous characters for taxonomic classification, and had been widely used in the past for this purpose, was found to be prone to convergence at different taxonomic levels (particularly within Nassariinae) when a rather comprehensive molecular phylogeny of the family was inferred (Galindo et al., 2016). This phylogeny provided the long needed scaffold to continue resolving the systematics of the family and opened the way to further phylogenetic studies focusing on relationships within particular clades. Here, we focused on one of these clades, which included nassariinae mostly from the Atlantic/Mediterranean region and was ascribed to genus Tritia (Galindo et al., 2016). We 
sequenced the near-complete (without the control region or partial gene sequences) mitogenomes of 20 species belonging to Tritia and reconstructed a highly resolved phylogeny, which included more than half of the species diversity of this genus (MolluscaBase, 2020c) as well as other nassariinae genera and Anentome sp. (subfamily Anetominae) as outgroup.

Within the first offshoot of the tree, $N$. jascksonianus and Nassarius sp. were recovered closer to Reticunassa than to other Nassarius, as previously suggested (Yang, Li, Kong, \& Yu, 2019). This is not surprising considering the geographic disparity of the samples and that not all species ascribed to Nassarius were included in the molecular phylogeny of the family, impeding proper assignment to clades (Galindo et al., 2016). Given the relative phylogenetic position of the two species and the large uncorrected $p$ distance separating them from other clades (16-18\%), they could be allocated in a new genus, whose formal description would need a larger taxon sampling and thorough morphological revision beyond the scope of this study.

According to the reconstructed phylogeny, the ascription of T. vaucheri to genus Tritia was strongly rejected. This taxon was originally described as Nassa (Himia) vaucheri (Pallary, 1906). After examining the syntype of this species, Cernohorsky (1975), transferred it to genus Chauvetia (in family Buccinidae). Later, Hoenselaar and Moolenbeek (1988) transferred the species to genus Nassarius and designated a lectotype. Finally, the new combination T. vaucheri (currently accepted in MolluscaBase, 2020c) was established in a checklist of marine mollusks recorded in Spanish marine waters (Gofas et al., 2017). Tritia vaucheri was recovered as an early divergent lineage in the phylogeny, sister to the Indo-Pacific clade (N. jascksonianus and Nassarius sp.) + Reticunassa, although with low statistical support. Hence, this species does not belong to genus Tritia, but to another Atlantic genus that is only distantly related and still needs to be determined (Genus incertae sedis, Gen. inc. sed.). Therefore, the general shell morphology resemblance of this taxon to other Tritia species would represent yet another case of convergence within Nassariidae (Galindo et al., 2016). Genus incertae sedis vaucheri is found in the southwestern Mediterranean coasts of Spain and in the nearby Atlantic coasts from south Portugal to Morocco being replaced by Nassarius argenteus from Senegal down to the Gulf of Guinea (Gofas, 2011). This latter species was not included in our study but may also belong to the same genus as Gen. inc. sed. vaucheri. The above-mentioned distribution is typical of several species of Tritia but also of several sympatric species of the African genus Naytia. Galindo et al. (2016) provisionally included in this latter genus 
$N$. glabrata (type species), N. granulosa, $N$. johni, from West African coasts, and $N$. priscardi from Madagascar, and they highlighted that the members of this genus were characterized by high morphological disparity. The type species and $N$. granulosa exhibit a smooth shell, similar to that of the species of the Bullia group, which led Simone \& Pastorino (2014) to erroneously include $N$. granulosa in the genus Bullia. Conversely, $N$. johni and $N$. priscardi, exhibit a reticulate shell sculpture. Gen. inc. sed. vaucheri is quite similar to these two latter species, so it could be possible that it belongs to Naytia (the position of this genus in the phylogeny of Galindo et al. 2016 is sister to Reticunassa, although with low support). It will be necessary to include mitogenomes of species from other genera (especially from West Africa) into the nassariid phylogeny in order to fully resolve the phylogenetic position of Gen. inc. sed. vaucheri and its generic placement.

The first split among the species attributed to the genus Tritia separated the Northwest Atlantic species T. obsoleta from the East Atlantic/Mediterranean species. This node is inconsistent with the results reported for the nassariid phylogeny (Galindo et al., 2016), in which T. obsoleta emerged in an internal position within Tritia, although with low bootstrap support. In the past, T. obsoleta was assigned as the type species to genus Ilyanassa (Stimpson, 1865), which was a taxon that included nassariids from North America (Cernohorsky, 1984). Although Ilyanassa had been widely used in previous literature, the internal position of T. obsoleta within Tritia in Galindo et al. (2016), led these authors to synonymize Ilyanassa with Tritia. In contrast, our results reveal a correlation between the phylogenetic position of T. obsoleta and its geographical distribution, which together with a significant level of genetic divergence (13.7\%) support the reinstatement of the genus Ilyanassa. To further resolve this part of the tree, it would be also necessary to include I. trivittata and other Northwest Atlantic nassariids (Rosenberg, 2009) into the phylogeny, as well as T. buchardi from southern Australia and New Zealand, which is close to Ilyanassa according to the phylogeny of Galindo et al. (2016).

\subsection{Taxonomy of Tritia}

Within the mostly East Atlantic/Mediterranean group, Clade I comprised 10 species, which are characterized by the presence of a shell with a more or less marked sculpture. The first diverging lineage of Clade I included T. ephamilla and T. elata + T. ovoidea. The former species is endemic to New Zealand and southern Australia whereas the latter two are found in the Mediterranean Sea and 
along the West African coasts down to Angola. The inclusion of T. ephamilla within Tritia was also recovered by Galindo et al (2016), although its exact sister group was not resolved. In addition to the geographic disparity, there is also a prominent morphological difference between T. ephamilla (globose with nodulose shell sculpture) and T. elata and T. ovoidea (slender-ovoid with slight spiral striations). The presence of T. ephamilla in this part of the tree could reflect a Thetyan origin of the Northeast Atlantic/Mediterranean mud snails and a subsequent southwards expansion towards tropical waters in the West Africa coasts (Galindo et al., 2016). A striking example of a similar disjoint distribution is constituted by the seagrass genus Posidonia, which displays the same contrasting biogeographic pattern. One species, P. oceanica, is distributed in the Mediterranean Sea whereas the other species of the genus are restricted to subtropical and temperate Australian waters (Aires et al., 2011). Other Northeast Atlantic/Mediterranean gastropods with a similar disjoint distribution and suspected of having Thetyan origin are the top shell snails of the subfamily Cantharidinae (Uribe et al., 2017b). In this case, the endemics to Oceania were recovered as sister to all Atlantic/ Mediterranean taxa. Tritia elata is a circalittoral species typical of soft bottoms of the continental shelf from the southern Iberian Peninsula to Angola. It shows a quite variable shell sculpture along the West African coast where it has been sometimes recorded as Nassarius semistriatus, a very similar fossil species extinct during the Pleistocene (Adam \& Knudsen, 1984). This last species, as well as the fossil species Nassarius martinelli (described by Gili, 1992 from the West Mediterranean Pliocene and differing from T. elata by its paucispiral protoconch) likely belong to the stem group of Tritia.

The other lineage within Clade I included $T$. denticulata sister to a rather diversified clade including T. tingitana sister to the "T. cuvierii complex" plus T. reticulata and T. nitida. The relative position of T. denticulata within clade I is in agreement with the Nassariidae molecular phylogeny (Galindo et al., 2016) but here showing high statistical support. Tritia denticulata is another circalittoral species distributed in the Alboran Sea and along the West African coasts down to Angola, including the Canary, Madeira and Cabo Verde islands (Rolán \& Hernández, 2005). This species is morphologically similar to a group of West African species, namely N. turbineus, $N$. webbei, $N$. desmoulioides, and N. arcadioi (Rolán \& Hernández, 2005), whose ascription to Tritia remains to be tested by their incorporation into the molecular phylogeny. In addition, the fossil species N. clathratus (Rolán \& Hernández, 2005) could belong to the stem lineage of Tritia. The 
phylogenetic position of T. tingitana (endemic of the Strait of Gibraltar), as the second diverging lineage within Clade I, is in clear disagreement with Galindo et al. (2016), who recovered T. tingitana as sister to T. corniculum with maximal support in a clade equivalent to our Clade III (see below). The two species are morphologically very different, and difficult to misidentify, suggesting a possible mislabeling error.

The last lineage of Clade I included three species corresponding to the "T. cuvierii complex" plus T. reticulata and T. nitida (Galindo et al., 2016; Aissaoui, Galindo, Puillandre, \& Bouchet, 2017). Within the “T. cuvierii complex”, T. cuvierii and T. unifasciata are sympatric along the Mediterranean coasts, and differ in the size of their shell, protoconch and egg capsules (Moreno \& Templado, 1994). Tritia unifasciata has faint axial ribs only in the first whorls of the shell. The third species of the complex here studied was T. tenuicosta, endemic to the Gulf of Gabès, whose relative position was in agreement to that recovered by Aissaoui, Galindo, Puillandre, \& Bouchet (2017). Another two endemic species of the Gulf of Gabès, T. lanceolata and T. djerbaensis also belong to the “T. cuvierii complex", and T. cuvierii may also include additional local cryptic species (Aissaoui, Galindo, Puillandre, \& Bouchet, 2017). According to Galindo et al. (2016), the West African T. miga would be closely related to the "T. cuvierii complex". Given its distribution and morphological similarity, the endemic species from Cabo Verde islands, T. caboverdensis (Rolán, 1984) may also belong to this complex (pending molecular confirmation).

The closely related and well-known species $T$. reticulata and T. nitida have been widely studied from different viewpoints (see Rolán \& Luque, 1994; Albaina et al., 2012; Couceiro et al., 2012, and references therein). Both species, sometimes misidentified, share similar life histories and dispersal capacities, but differ in their environmental affinities. The netted dog-whelk T. reticulata inhabits a wide range of marine soft bottoms and is mainly an East Atlantic species with a more or less continuous distribution from the British Isles to Morocco and the Canary Islands that enters into western Mediterranean. The estuarine dog-welk T. nitida is restricted to sheltered brackish habitats with a patchy distribution in the Mediterranean Sea and Black Sea coasts as well as in the East Atlantic Ocean from Morocco to Norway (Albaina et al., 2012). Therefore, this latter species probably diverged from $T$. reticulata by a habitat shift from marine to brackish waters.

Clade II in our phylogeny (also recovered in Galindo et al., 2016) included T. varicosa (often previously recorded as T. pygmaea) and T. incrassata. Both species are sympatric in the 
Mediterranean Sea and along the Northeast Atlantic coast from Sweden to the Iberian Peninsula. They are similar in terms of shell size (about $10 \mathrm{~mm}$ ) and ornament (little nodules on shell formed by costae and spiral ridges), but the nodules of T. varicosa are much smaller, squarer and more upstanding than those of T. incrassata (Fretter, Graham \& Andrews, 1986). Divergence between both species could have been caused by adaptation to dissimilar habitats: mainly rocky bottoms in $T$. incrassata and soft bottoms with beds of Zostera and Cymodocea seagrasses in T. varicosa (JT, pers. obs.). According to Galindo et al. (2016), T. senegalensis and T. goreensis, and several other species endemic to Senegal, would be sister to the northern species within this clade.

With a planktotrophic larval stage, $T$. incrassata is widely distributed along the Mediterranean and Northeast Atlantic region. The pairwise uncorrected $p$ distance between the two studied individuals of T. incrassata from two distant locations (Norway and the Spanish Mediterranean) reached 3.8\%, which was even higher than the value obtained for sibling species such as T. neritea and T. pellucida (Supporting Information Table S4). This result indicates that the diversity of $T$. incrassata was previously underestimated and that it may include putative cryptic species. This hypothesis will need to be further confirmed by the inclusion of data from nuclear genes to discard potential events of incomplete lineage sorting and hybridization (Alexander et al., 2017). A previous phylogeographic study on T. nitida suggested the existence of two glacial refugia during the Pleistocene, one in the Atlantic (around the Iberian Peninsula) and the other in the Paleo-Mediterranean Sea (Albaina et al., 2012). It may well be the case that the observed genetic divergence between the two populations of T. incrassata-NW and -SP is a result of isolation in the two Pleistocene refugia. After the last glaciation, the Strait of Gibraltar and the Almeria-Oran oceanographic front would have acted as well documented barriers to gene flow between the Atlantic and Mediterranean populations, as reported for T. nitida (Albaina et al., 2012) and other marine organisms (Patarnello, Volckaert, \& Castilho, 2007). Our results show the need for further studies with dense sampling at the population level along the distribution range of T. incrassata in order to determine its diversity and elucidate the evolutionary processes driving its diversification.

Finally, Clade III in the reconstructed tree is composed of eight species with smooth (absence of sculpture) shells as shared derived character. The absence of sculpture may have occurred independently in several lineages of Nassariinae, some of which were already defined in the Early-Middle Miocene (Manganelli, Spadini \& Martini, 2010). Phylogenetic relationships within 
Clade III are in agreement with those previously reported (Galindo et al., 2016; Aissaoui, Galindo, Puillandre, \& Bouchet, 2017), except for the relative phylogenetic position of T. mutabilis, which here is moderately supported as sister to T. pfeifferi and was not resolved in previous studies. In Galindo et al. (2016), T. conspersa was recovered as sister to T. pfeifferi within this clade. The earliest divergent lineage within our Clade III includes species of the “T. corniculum complex". The pairwise uncorrected $p$ distance obtained between T. pallaryana (a recently described species from the Gulf of Gabès; Aissaoui, Galindo, Puillandre, \& Bouchet, 2017) and T. corniculum showed the least value of all comparisons (0.6\%; Supporting Information Table S4), and could cast doubts on the taxonomic validity of the former. However, we conservatively maintain $T$. pallaryana as valid given significant ecological and morphological differences (Aissaoui, Galindo, Puillandre, \& Bouchet, 2017) as well as because the sequence divergence value falls within the so-called "grey zone" of speciation (Roux et al., 2016). Tritia elongata, also endemic of the Gulf of Gabès, was also recovered within the “T. corniculum complex”, in agreement with Aissaoui, Galindo, Puillandre, \& Bouchet (2017). Tritia corniculum inhabits sandy-muddy bottoms in shallow, sheltered waters of brackish and marine environments, typically in coastal lagoons (Iannotta, Toscano, \& Patti, 2009) with a patchy distribution along the Mediterranean and Northeast Atlantic coasts. Its direct development without a planktonic larval phase, together with the discontinuous distribution of its habitat, may promote genetic isolation among populations and incipient speciation processes, which are reflected in great intra-specific morphological variability (Iannotta, Toscano, \& Patti, 2009; Gofas, 2011).

The remaining species of Clade III were T. mutabilis (type species of the currently unaccepted genus Sphaeronassa) and T. pfeifferi sister to a lineage comprising T. grana (type species of the currently unaccepted genus Naytiopsis) and the flattened-shell sibling species T. neritea and T. pellucida (previously assigned to the currently unaccepted genus Cyclope). While T. mutabilis inhabits infralittoral fine sands and muddy sand banks along the Mediterranean coasts, T. pfeifferi is an East Atlantic species (from northeastern Spain to Mauritania) adapted to shallow and intertidal sheltered soft bottoms that is replaced by T. conspersa in Canary Islands (Gofas, 2011). On the other hand, while T. grana inhabits clean, mobile, fine infralittoral sands in open waters, T. neritea and T. pellucida are characteristic of sandy-muddy shallow bottoms in estuaries, sheltered bays and marine lagoons, often subject to variable salinity (even brackish) waters (Gili \& Martinell, 2000; 
Gofas, 2011).

\subsection{Protoconch evolution}

The robust phylogeny of Tritia prompts some considerations about the evolution of the mode of larval development within the genus. Since Thorson (1950), a large body of studies has focused on the evolution of the mode of larval development in marine invertebrates. Transitions between modes of development are considered highly asymmetrical from species with feeding larval stages (planktotrophic) to species with non-feeding larval development (lecithotrophic), with the Modica et al., 2020). In both extant and fossil gastropods, the presence of a paucispiral or a multispiral protoconch is used as proxy for the lecithotrophic and planktotrophic alternative modes of development, respectively (Shuto, 1974; Jablonski \& Lutz, 1980). The shift in mode of larval development has important evolutionary consequences, as planktotrophic larvae are able to survive longer in the water column and thus have higher dispersal capabilities than lecithotrophic larvae, which barely move from the places where eggs were laid (Shank, 2009). Hence, species with planktotrophic larvae usually are widely distributed and maintain high levels of gene flow between populations, whereas species with lecithotrophic larvae show narrower distribution ranges and are prone to allopatric speciation processes (Collin, 2001; Cunha et al., 2005; Abalde et al. 2017; Modica, 2020).

The ancestor of the genus Tritia was inferred to have had planktotrophic veliger larvae, as is widely assumed for caenogastropods (Ponder \& Lindberg, 1997, 2019; Modica et al., 2020). The lecithotrophic state is a derived condition, which evolved independently in at least three terminal lineages: species within Clade III as well as species of the “T. cuvierii complex”, and T. tingitana within Clade I. In addition, some but not all of the species of the "T. denticulata complex" have planktotrophic development, and the potentially closely related Nassarius turbineus from the Gulf of Guinea (not included in our phylogeny) exhibits paucispiral protoconch indicative of another independent shift to lecithotrophy within Clade I. The loss of planktotrophy has occurred several other times independently within Nassariinae including some Reticunassa species (Galindo et al., 2016). Transitions from planktotrophic to lecithotrophic larval development have been recurrent in diverse caenogastropod lineages (e.g. Lieberman, Allmon, \& Eldredge, 1993; Reid, Rumbak, \& 
Thomas, 1996; Duda \& Palumbi, 1999; Collin, 2004) and the fossil record from the Northeast Atlantic and Mediterranean shows this trend towards the loss of planktotrophy in several taxa as recently as the Pliocene and Pleistocene periods (Oliverio, 1996). During this evolutionary transition, intermediate forms of development (facultative feeding larvae, short-lived planktotrophs, species with dispersal polymorphisms, and species showing poecilogony, i.e., the presence of the two types of development) should appear (Collin, 2012). However, these intermediate stages are generally ephemeral in evolutionary terms, and either go extinct or evolve into direct developers. In rare cases, the phenotypically plastic intermediates might persist if they show a selective advantage under heterogeneous environmental conditions compared to the two extremes (Collin, 2012). In gastropods, the known cases of poecilogony are prevalent among sea slugs in the suborder Sacoglossa, short-lived planktotrophs are found among calyptraeids, and facultative lecithotrophy has been reported in the nudibranch genus Phestilla (Collin, 2012).

The frequent and asymmetric transition to lecithotrophy may have key macroevolutionary consequences because it implies shifts in rates of speciation and extinction. On the one hand, species with lecithotrophic development have higher rates of speciation, and thus they are assumed to progressively increase through time compared to widely dispersing species. For instance, Harzhauser \& Kowalke (2004) studied the nassariid gastropods from the Neogene Paratethys and observed a trend in the fossil record towards the local appearance of species showing paucispiral protoconch in rather short time periods. On the other hand, regional environmental perturbations could cause the extinction of narrowly ranging species, whereas more broadly dispersed species could survive elsewhere (e.g., Jablonski, 1986). Therefore, higher extinction rates would lower the net diversity of lecithotrophs despite the fact that this condition originates frequently, and this evolutionary pattern could explain the long-term maintenance of planktotrophy (Collin \& Moran, 2018; Modica et al., 2020). In this regard, several authors have highlighted that planktotrophic species are more resistant to extinction and persist longer on geological time scales relative to lecithotrophic species (e.g. Hansen, 1980; Jablonski, 1986; Crampton et al., 2010). For instance, planktotrophic species of the family Nassariidae from the Neogene fossil deposits of the Atlantic/Mediterranean area had a mean duration of 9.8 million years, whereas the average duration of several non-planktotrophic species was 2.8 million years (Gili \& Martinell, 1994). 
on extinction rates), it is likely that even if most living species of a taxon are included in a molecular phylogeny, the total number of independent transitions to direct development will be underestimated due to ignorance of what may have occurred in extinct lineages (Collin \& Moran, 2018). Hence, fossil data appears necessary to testify and supplement the results of molecular data to improve the knowledge of the evolution of this important trait in the life cycle in the East Atlantic and Mediterranean nassariid gastropods (Lozouet \& Galindo, 2015; Van Dingenen, Ceuleman, Landau, \& da Silva, 2015). For instance, the West Mediterranean Pliocene species Nassarius martinelli is distinguished from the extant planktotrophic T. elata by its paucispiral protoconch, indicative of lecithotrophic development (Gili, 1992). Nassarius martinelli was apparently quite local in South France, inhabiting circallittoral bottoms, and became extinct at the end of the Pliocene or during the first glacial period of the Pleistocene, probably as a consequence of glacio-eustatic processes producing a sharp drop in sea level (Gili, 1992). Tritia neritea and $T$. pellucida are the only extant species among Nassariinae gastropods with a depressed, discoidal shell, dorsally convex and flatter in the ventral side. The early Pliocene fossil Tritia migliorinii (as Cyclope migliorinii) shows the above-mentioned peculiar shell morphology (Gili \& Martinell, 1999, 2000) and is considered a member of the stem group. It has a multispiral protoconch (i.e, planktotrophic larval development) implying a putative independent transition to direct development within this lineage of Clade III. Another instance of shift in mode of larval development could be that of some fossil forms closely related to T. mutabilis from the Mediterranean and Atlantic Pliocene that may have had a rather short planktotrophic phase (Gili \& Martinell, 1990) suggesting yet another transition from plankotrophy to lecithotrophy within Clade III.

\subsection{Tempo of diversification}

Our reconstructed time tree dates the origin of Nassarinae genera throughout the Oligocene, which is consistent with the fossil record (Lozouet \& Galindo, 2015). A trend towards cooler conditions during the Oligocene (Zachos et al., 2001) is likely to have favored temperate taxa (Uribe et al, 2017b). During this period, the onset of deep-water circulation between the Arctic and North Atlantic Oceans (Davies et al., 2001) may have constituted a strong barrier to marine taxa dispersal between North America and Eurasia. In this regard, the separation of Ilyanassa from Tritia at both 
sides of the Atlantic and the subsequent diversification of the main eastern lineages occurred right after the Oligocene-Miocene transition. The late Oligocene is thought to have been a time of relatively warm global temperatures while in the early Miocene there was a rapid expansion of the Antarctica ice sheet and large-scale climate fluctuations attributed to an Earth orbital anomaly (Zachos et al., 2001). These global climate oscillations might have triggered diversification events leading to the extant genera within Nassariinae. In parallel, continental drift produced the collision of Laurasia and Gondwana about 19 Mya and the final closure of the Eastern Tethys Seaway (the so-called Terminal Tethyan event) around 14 Mya (Harzhauser et al., 2007; Okay, Zattin, \& Cavazza, 2010; Hou \& Li, 2018). The closure definitively ended the previous flow of tropical marine gastropods between the Indian Ocean and the proto-Mediterranean Basin (Hamon et al., 2013). In fact, fragmentation of the Tethys Ocean has been suggested as the main driver of the disjunct, endemic and relict distributions of many Tethyan lineages (i.e. Ozawa et al., 2009; Rodríguez-Flores et al., 2020). Accordingly, the puzzling phylogenetic position of the Australian and New Zealand endemic T. ephamilla, which diverged about 16 Mya from East Atlantic/ Mediterranean taxa (as well as the sister relationship of the Australian T. buchardi and the Northwest Atlantic I. obsoleta; Galindo et al. 2016), would represent one of the latest split events prior to the closure.

The origin of extant species started at the end of the Miocene, when there was a sustained global cooling event that started about 12 Mya and culminated about 5.4 Mya (Herbert et al., 2016), causing an eustatic sea level drop of -10 to -30 m (Hodell et al., 2001). Simultaneously, and because of tectonic movements, the connection between the East Atlantic Ocean and the Mediterranean Sea at the Strait of Gibraltar was closed, resulting in the desiccation of the Mediterranean basin, the well-known Messinian Salinity Crisis (MSC, 5.96 to 5.33 Mya; Krijgsman et al., 1999). Altogether, these climatic, eustatic, and tectonic changes resulted in drastic shifts in the paleoecosystems of the East Atlantic/Mediterranean region that likely triggered speciation, as has been shown for other groups (Davis et al., 2016, Abalde et al., 2017; Uribe et al., 2017b). The ecological adaptation to the variable salinity waters of this period likely promoted the divergence between $T$. nitida and $T$. reticulata, between T. mutabilis and T. pfeifferi, and between T. grana and T. neritea/ T. pellucida, which were dated in the Miocene according to the chronogram. The independent transitions to the direct mode of larval development were also dated in this period. The transition from the Pliocene 
to the Pleistocene was characterized by a sudden cooling (about 2.6 Mya) and subsequent glacial-interglacial periods with extreme climate oscillations and drastic eustatic sea level changes (Filippelli \& Flores, 2009), which may explain the divergence between sibling taxa such as $T$. pallaryana and T. corniculum, T. neritea and T. pellucida, and the two distant populations of T. incrassata.

Our estimates of major divergence events within Nassariinae are about 11-24 Mya younger than those previously reported in Galindo et al. (2016), which dated the origin of the lineage leading to Tritia and Ilyanassa to 48 Mya (Eocene), separation of both genera at 32 Mya (Oligocene), and the diversification of main lineages within Tritia during the Miocene. The main difference between the two inferences relies on the calibration points, which in Galindo et al. (2016) were chosen to date the much older Nassariidae origin within Buccinoidea (note that two calibration points were the same in both studies) and the fewer representatives of Tritia in their chronogram. Given that our calibration points were chosen to fit better in time the question at hand, and that there is congruence of our estimated dates with climatic, eustatic, and tectonic changes, as well as the rich fossil record of East Atlantic/Mediterranean Nassariinae during the Miocene and Pliocene (Cernohorsky, 1984), we propose the present time tree as our preferred working hypothesis for the timing of the origin and diversification of genus Tritia.

\section{CONCLUSIONS}

The reconstructed mitogenomic tree provided high resolution of Tritia phylogenetic relationships, and allowed determining that Gen. inc. sed. vaucheri does not belong to the genus. Given its distribution, this result calls for a morphological and ecological revision of the West African genus Naytia. The strongly supported sister group relationship between the Northwest Atlantic I. obsoleta and the three East Atlantic/Mediterranean clades (I-III), justify the reinstatement of the genus Ilyanassa, and shows the need for a careful revision of the two genera. Within Tritia, the additional described species endemic to West Africa need to be incorporated into the mitogenomic phylogeny. In addition, the notable pairwise divergence between the two $T$. incrassata specimens from Norway and the Spanish Mediterranean strongly suggests the possibility of the existence of cryptic species that needs to be further confirmed with nuclear data and a larger sampling. The robust phylogeny allowed inferring that the ancestor of Nassariinae had planktotrophic larvae and that several 
independent transitions to lecithotrophic larvae occurred during the evolutionary history of the group. Hence, it would be interesting to compare morphological and gene expression changes during development of Nassariinae lecithotrophic larvae in search for footprints of convergence. The inferred divergence dates suggest an important role of climatic, eustatic, and tectonic changes during the Oligocene, Miocene, and Pleistocene influencing local Atlantic/Mediterranean paleoecosystems and promoting the origin, main lineage diversification, and recent speciation events within Tritia, respectively. Several recent divergences between some pairs of close species could be due to a habitat shift from open marine to sheltered brackish waters. Our study indicates that mt genomes could render similar robust results when applied to other Nassariinae genera and would be highly useful in reconstructing a robust phylogeny of the entire Nassariidae family, hence providing the long-needed framework to understand diversification and adaptation processes underpinning the evolutionary success of this family.

\section{ACKNOWLEDGEMENTS}

We are grateful to the colleagues who helped us collect in the Gulf of Gabès or sent us specimens from other Mediterranean, Atlantic, Australian and New-Zealand localities: Manuel Caballer, Serge Gofas, Philippe Maestrati, Javier Martin, Jean Pierre Miquel, Leopoldo Moro, Marco Oliverio, Gianni Spada, Jacques Pelorce, Emmanuel Vassard, and Bruce Marshall. Barbara Buge and Sadie Mills are also thanked for their help in curating the MNHN and NIWA samples, respectively. We thank two anonymous reviewers for detailed and insightful comments on a previous version of the manuscript. This work was funded by the Spanish Ministry of Economy, Industry and Competitiveness (CGL2016-75255-C2-1-P [AEI/FEDER, UE] to R.Z.; BES-2014-069575 to S.A). Yi Yang was supported by a scholarship from the China Scholarship Council (CSC-201806330034) for studying and living abroad. The project has received funding from the European Research Council (ERC) under the European Union's Horizon 2020 research and innovation programme (grant agreement No. 865101) to NP. 


\section{REFERENCES}

Abalde, S., Tenorio, M. J., Afonso, C. M., Uribe, J. E., Echeverry, A. M., \& Zardoya, R. (2017). Phylogenetic relationships of cone snails endemic to Cabo Verde based on mitochondrial genomes. BMC Evolutionary Biology, 17, 231. https://doi.org/10.1186/s12862-017-1069-x

Abascal, F., Zardoya, R., \& Telford, M. J. (2010). TranslatorX: multiple alignment of nucleotide sequences guided by amino acid translations. Nucleic Acids Research, 38, W7-W13. https://doi.org/10.1093/nar/gkq291

Adam, W., \& Knudsen, J. (1984). Révision des Nassariidae (Mollusca: Gastropoda prosobranchia) de l'Afrique occidentale. Bulletin de l'Institut Royal des Sciences Naturelles de Belgique, Biologie, 55, 1-95, pls. 1-5.

Aires, T., Marbà, N., Cunha, R. L., Kendrick, G. A., Walker, D. I., Serrão, E. A., ... \& Arnaud-Haond, S. (2011). Evolutionary history of the seagrass genus Posidonia. Marine Ecology Progress Series, 421, 117-130. https://doi.org/10.3354/meps08879

Aissaoui, C., Galindo, L. A., Puillandre, N., \& Bouchet, P. (2017). The nassariids from the Gulf of Gabès revisited (Neogastropoda, Nassariidae). Marine Biology Research, 13, 370-389. https://doi.org/10.1080/17451000.2016.1273528

Albaina, N., Olsen, J. L., Couceiro, L., Ruiz, J. M., \& Barreiro, R. (2012). Recent history of the European Nassarius nitidus (Gastropoda): phylogeographic evidence of glacial refugia and colonization pathways. Marine biology, 159, 1871-1884. https://doi.org/10.1007/s00227-012-1975-9

Albright, L. B., Sanders, A. E., Weems, R. E., Cicimurri, D. J., \& Knight, J. L. (2019). Cenozoic vertebrate biostratigraphy of South Carolina, U.S.A. and additions to the fauna. Bulletin of the Florida Museum of Natural History, 57, 77-236.

Alexander, A. M., Su, Y. C., Oliveros, C. H., Olson, K. V., Travers, S. L., \& Brown, R. M. (2017). Genomic data reveals potential for hybridization, introgression, and incomplete lineage sorting to confound phylogenetic relationships in an adaptive radiation of narrow-mouth frogs. Evolution, 71, 475-488. https://doi.org/10.1111/evo.13133 
Allmon, W. D. (1990). Review of the Bullia group (Gastropoda: Nassariidae) with comments on its evolution, biogeography, and phylogeny. Bulletins of American Paleontology, 99, 1-179.

Andrews, S. (2010). FastQC: a quality control tool for high throughput sequence data. http://www.bioinformatics.babraham.ac.uk/projects/fastqc/

Báldi, T. (1973). Mollusc fauna of the Hungarian Upper Oligocene (Egerian): Studies in stratigraphy, palaeoecology, palaeogeography and systematics (p. 511). Budapest: Akadémiai Kiadó.

Bernt, M., Donath, A., Jühling, F., Externbrink, F., Florentz, C., Fritzsch, G., ... \& Stadler, P. F. (2013). MITOS: improved de novo metazoan mitochondrial genome annotation. Molecular Phylogenetics and Evolution, 69, 313-319. https://doi.org/10.1016/j.ympev.2012.08.023

Bouchet, P., Rocroi, J. P., Hausdorf, B., Kaim, A., Kano, Y., Nützel, A., ... \& Strong, E. E. (2017). Revised classification, nomenclator and typification of gastropod and monoplacophoran families. Malacologia, 61, 1-526. https://doi.org/10.4002/040.061.0201

Brown, A. C. (1982). The biology of sandy-beach whelks of the genus Bullia (Nassariidae). Oceanography and Marine Biology: An Annual Review, 20, 309-361.

Castresana, J. (2000). Selection of conserved blocks from multiple alignments for their use in phylogenetic analysis. Molecular Biology and Evolution, 17, 540-552. https://doi.org/10.1093/oxfordjournals.molbev.a026334

Cernohorsky, W. O. (1975). The taxonomy of some West American and Atlantic Nassariidae based on their type-specimens. Records of the Auckland Institute and Museum, 12, 121-173.

Cernohorsky, W. O. (1984). Systematics of the family Nassariidae (Mollusca: Gastropoda). Bulletin of the Auckland Institute and Museum, 14, 1-356.

Chen, Z. Y., \& Zhang, S. P. (2012). Molecular phylogeny of Nassarius (Gastropoda, Nassariidae) based on 16s rRNA gene sequences. Acta Zootaxonomica Sinica, 37, 467-472.

Collin R. (2001). The effects of mode of development on phylogeography and population structure of North Atlantic Crepidula (Gastropoda: Calyptraeidae). Molecular Ecology, 10, 2249-2262. https://doi.org/10.1046/j.1365-294x.2001.01372.x 
Collin, R. (2004). Phylogenetic effects, the loss of complex characters, and the evolution of development in calyptraeid gastropods. Evolution, 58, 1488-1502. https://doi.org/10.1111/j.0014-3820.2004.tb01729.x

Collin, R. (2012). Non-traditional life history choices: what can “intermediates” tell us about evolutionary transitions between modes of invertebrate development? Integrative and Comparative Biology, 52, 128-137. https://doi.org/10.1093/icb/ics065

Collin, R., \& Moran, A. (2018). Evolutionary transitions in mode of development. In: T. J. Carrier, A. M. Reitzel \& A. Heyland (Eds.), Evolutionary Ecology of Marine Invertebrate Larvae (pp. 51-66). Oxford University Press. https://doi.org/10.1093/oso/9780198786962.003.0004

Cossmann, M. (1901). Essais de paléoconchologie comparée, 4.Paris (Cossmann): 293 pp., 10 pls.

Couceiro, L., López, L., Sotka, E. E., Ruiz, J. M., \& Barreiro, R. (2012). Molecular data delineate cryptic Nassarius species and characterize spatial genetic structure of $N$. nitidus. Journal of the Marine Biological Association of the UK, 92, 1175-1182.

Crampton, J. S., Cooper, R. A., Beu, A. G., Foote, M., \& Marshall, B. A. (2010). Biotic influences on species duration: interactions between traits in marine molluscs. Paleobiology, 36, 204-223. https://doi.org/10.1666/09010.1

Cunha, R.L., Castilho, R., Rüber, R. \& Zardoya, R. (2005) Patterns of cladogenesis in the venomous marine gastropod genus Conus from the Cape Verde Islands. Systematic Biology, 54, 634-650. https://doi.org/10.1080/106351591007471

Cunha, R. L., Grande, C., \& Zardoya, R. (2009). Neogastropod phylogenetic relationships based on entire mitochondrial genomes. BMC Evolutionary Biology, 9, 210. https://doi.org/10.1186/1471-2148-9-210

Davis, K. E., Hill, J., Astrop, T. I., \& Wills, M. A. (2016). Global cooling as a driver of diversification in a major marine clade. Nature Communications, 7, 13003. https://doi.org/10.1038/ncomms13003

Davies, R., Cartwright, J., Pike, J. \& Line, C. (2001) Early Oligocene initiation of North Atlantic deep water formation. Nature, 410, 917-920. https://doi.org/10.1038/35073551

Drummond, A., \& Rambaut, A. (2007). BEAST: Bayesian evolutionary analysis by sampling trees. BMC Evolutionary Biology, 7, 214. https://doi.org/10.1186/1471-2148-7-214 
Duda, T. F., \& Palumbi, S. R. (1999). Developmental shifts and species selection in gastropods. Proceedings of the National Academy of Sciences USA, 96, 10272-10277. https://doi.org/10.1073/pnas.96.18.10272

Felsenstein, J. (1981). Evolutionary trees from DNA sequences: a maximum likelihood approach. Journal of Molecular Evolution, 17, 368-376. https://doi.org/10.1007/BF01734359

Filippelli, G. M., \& Flores, J. A. (2009). From the warm Pliocene to the cold Pleistocene: A tale of two oceans. Geology, 37, 959-960. https://doi.org/10.1130/focus102009.1

Fretter, V., Graham, A., \& Andrews, E. (1986). The Prosobranch molluscs of Britain and Denmark. Part 8 : Neogastropoda. Journal of Molluscan Studies, Suppl. 15, 435-556.

Galindo, L. A., Kool, H. H., \& Dekker, H. (2017). Review of the Nassarius pauper (Gould, 1850) complex (Gastropoda, Nassariidae). Part 3, reinstatement of the genus Reticunassa, with the description of six new species. European Journal of Taxonomy, 275, 1-43. https://doi.org/10.5852/ejt.2017.275

Galindo, L. A., Puillandre, N., Utge, J., Lozouet, P., \& Bouchet, P. (2016). The phylogeny and systematics of the Nassariidae revisited (Gastropoda, Buccinoidea). Molecular Phylogenetics and Evolution, 99, 337-353. https://doi.org/10.1016/j.ympev.2016.03.019

Gili, C. (1992). Nassarius martinelli (Neogastropoda: Nassariidae) del Plioceno del Mediterráneo occidental. Revista Española de Paleontología, 7, 167-173.

Gili, C., \& Martinell, J. (1990). Aportación al conocimiento de subgénero Sphaeronassa (Locard, Neogastropoda) del Plioceno del mediterráneo y del Atlántico adyacente. Revista Española de Paleontología, 5, 19-33.

Gili, C., \& Martinell, J. (1993). The distribution of Pliocene Nassariidae (Mollusca, Gastropoda) from the Western Mediterranean: palaeoecological and historical considerations. Mededelingen van de Werkgroep voor Tertiaire en Kwartaire Geologie, 30(1-2), 29-39.

Gili, C., \& Martinell, J. (1994). Relationships between species longevity and larval ecology in nassariid gastropods. Lethaia, 27, 291-299. https://doi.org/10.1111/j.1502-3931.1994.tb01577.x

Gili, C., \& Martinell, J. (1999). Revisión del género Cyclope Risso, 1826 (Gastropoda: Nassariidae) 
en el Plioceno mediterráneo. Revista Española de Paleontología, 14, 149-158.

833

834

835

836

837

838

839

840

Gili, C., \& Martinell, J. (2000). Phylogeny, speciation and species turnover. The case of the Mediterranean gastropods of genus Cyclope Risso, 1826. Lethaia, 33, 236-250. https://doi.org/10.1080/00241160025100080

Glawe, L. N., Anderson, J. F., \& Bell, D. E. (2014). Late Paleocene examples of residual coloration and embryonic features in juvenile marine mollusks from Northwest Louisiana. Palaeontologia Electronica, 17, 30A.

Gofas, S. (2011). Familia Nassariidae. In: Moluscos marinos de Andalucía, vol. 1. (Gofas, S., Moreno, D., \& Salas, C. Coords.). Servicio de Publicaciones e Intercambio Científico, Universidad de Málaga, pp. 297-305.

Gofas, S., Luque, Á, Templado, J., \& Salas, C. (2017). A national checklist of marine Mollusca in Spanish waters. Scientia Marina, 81, 241-254

Goulding, M. Q., \& Lambert, J. D. (2016). Mollusc models I. The snail Ilyanassa. Current Opinion in Genetics \& Development, 39, 168-174. https://doi.org/10.1016/j.gde.2016.07.007

Haasl, D. M. (2000). Phylogenetic relationships among nassariid gastropods. Journal of Paleontology, 74, 839-852. https://doi.org/10.1017/S0022336000033047

Hamon, N., Sepulchre, P., Lefebvre, V., \& Ramstein, G. (2013). The role of eastern Tethys seaway closure in the Middle Miocene Climatic Transition (ca. 14 Ma). Climate of the Past, 9, 26872702. https://doi.org/10.5194/cp-9-2687-2013

Hansen, T. A. (1980). Influence of larval dispersal and geographic distribution on species longevity in neogastropods. Paleobiology, 6, 193-207. https://doi.org/10.1017/S0094837300006758

Harasewych, M. G. (1998). Family Nassariidae. In P. L. Beesley, G. J. B Ross \& A. Wells (Eds.), Mollusca: the southern synthesis. Fauna of Australia (pp. 829-831). Melbourne, CSIRO Publishing.

Harzhauser, M., \& Kowalke, T. (2004). Survey of the nassariid gastropods in the Neogene Paratethys. Archiv für Molluskenkunde, 133(1-2), 1-63.

Harzhauser, M., Kroh, A., Mandic, O., Piller, W. E., Göhlich, U., Reuter, M., \& Berning, B. (2007). Biogeographic responses to geodynamics: a key study all around the Oligo-Miocene Tethyan 
Seaway. Zoologischer Anzeiger-A Journal of Comparative Zoology, 246, 241-256. https://doi.org/10.1016/j.jcz.2007.05.001

Hayashi, S. (2004). The molecular phylogeny of the Buccinidae (Caenogastropoda: Neogastropoda) as inferred from the complete mitochondrial 16S rRNA gene sequences of selected representatives. Molluscan Research, 25, 85-98.

Herbert, T. D., Lawrence, K. T., Tzanova, A., Peterson, L. C., Caballero-Gill, R., \& Kelly, C. S. (2016). Late Miocene global cooling and the rise of modern ecosystems. Nature Geoscience, 9, 843-847. https://doi.org/10.1038/ngeo2813

Ho, S. Y., \& Phillips, M. J. (2009). Accounting for calibration uncertainty in phylogenetic estimation of evolutionary divergence times. Systematic Biology, 58, 367-380.

Hodell, D. A., Curtis, J. H., Sierro, F. J., \& Raymo, M. E. (2001). Correlation of late Miocene to early Pliocene sequences between the Mediterranean and North Atlantic. Paleoceanography, 16, 164-178. https://doi.org/10.1029/1999PA000487

Hoenselaar, H.J., \& Moolenbeek, R.G. (1988). The identity of Nassarius vaucheri (Pallary, 1906) (Gastropoda Prosobranchia). Basteria, 52, 45-47.

Hou, Z., \& Li, S. (2018). Tethyan changes shaped aquatic diversification. Biological Reviews, 93, 874-896. https://doi.org/10.1111/brv.12376

Huelsenbeck, J., \& Ronquist, F. (2001). MrBayes: Bayesian inference of phylogenetic trees. Bioinformatics, 17, 754-755.

Hwang, P. A., Tsai, Y.H., Deng, J.F., Cheng, C.A., Ho, P.H., \& Hwang, D.F. (2005) Identification of tetrodotoxin in a marine gastropod (Nassarius glans) responsible for human morbidity and mortality in Taiwan. Journal of Food Protection, 68, 1696-1701. https://doi.org/10.4315/0362-028x-68.8.1696

Iannotta, M. A., Toscano, F., \& Patti, F. (2009). Nassarius corniculus (Olivi, 1792) (Caenogastropoda: Nassariidae): a model of environmental complexity of Italian brackish and marine habitats. Marine Ecology, 30, 106-115. https://doi.org/10.1111/j.1439-0485.2008.00263.x

Jablonski, D. \& Lutz, R. A. (1980) Molluscan larval shell morphology: ecological and paleontological applications. In Rhoads, D.C. and Lutz, R.A. (eds) Skeletal growth of aquatic 
organisms. New York: Plenum Press, pp. 323-377.

Jablonski, D. (1986). Larval ecology and macroevolution of marine invertebrates. Bulletin of Marine Sciences, 39, 565-587.

Kalyaanamoorthy, S., Minh, B. Q., Wong, T. K. F., von Haeseler, A., \& Jermiin, L. S. (2017). ModelFinder: Fast model selection for accurate phylogenetic estimates. Nature Methods, 14, 587-589. https://doi.org/10.1038/nmeth.4285

Katoh, K., \& Standley, D. M. (2013). MAFFT multiple sequence alignment software version 7: improvements in performance and usability. Molecular Biology and Evolution, 30, 772-780. https://doi.org/10.1093/molbev/mst010

Kearse, M., Moir, R., Wilson, A., Stones-Havas, S., Cheung, M., Sturrock, S., ... \& Thierer, T. (2012). Geneious Basic: an integrated and extendable desktop software platform for the organization and analysis of sequence data. Bioinformatics, 28, 1647-1649. https://doi.org/10.1093/bioinformatics/bts199

Kool, H. H., \& Dekker, H. (2006). Review of the Nassarius pauper (Gould, 1850) complex (Gastropoda, Nassariidae). Part. 1, with the description of four new species from the Indo-West-Pacific. Visaya, 1, 56-77.

Kool, H. H., \& Dekker, H. (2007). Review of the Nassarius pauper (Gould, 1850) complex (Gastropoda, Nassariidae). Part 2, the Western Indian Ocean species, with the description of two new species and introducing a nomen novum. Visaya, 2, 62-77.

Krijgsman, W., Hilgen, F. J., Raffi, I., Sierro, F. J., \& Wilson, D. S. (1999). Chronology, causes and progression of the Messinian salinity crisis. Nature, 400, 652-655. https://doi.org/10.1038/23231

Landau, B., Marquet, R. \& Grigis, M. (2003) The Early Pliocene Gastropoda (Mollusca) of Estepona, Southern Spain. Part 1: Vetigastropoda. Paleontos 3, 1-87

Landau, B., da Silva, C. M., \& Gili, C. (2009). The early Pliocene Gastropoda (Mollusca) of Estepona, southern Spain, 8. Nassariidae. Palaeontos, 17, 1-101.

Lanfear, R., Frandsen, P. B., Wright, A. M., Senfeld, T., \& Calcott, B. (2017). PartitionFinder 2: new methods for selecting partitioned models of evolution for molecular and morphological 
phylogenetic analyses. Molecular Biology and Evolution, 34, 772-773. https://doi.org/10.1093/molbev/msw260

Laslett, D., \& Canbäck, B. (2008). ARWEN: a program to detect tRNA genes in metazoan mitochondrial nucleotide sequences. Bioinformatics, 24, 172-175. https://doi.org/10.1093/bioinformatics/btm573

Lieberman, B. S., Allmon, W. D., \& Eldredge, N. (1993). Levels of selection and macroevolutionary patterns in the turritellid gastropods. Paleobiology, 19, 205-215.

Lozouet, P. (1999). Nouvelles espèces de gastéropodes (Mollusca: Gastropoda) de l'Oligocène et du Miocène inférieur d’Aquitaine (Sud-Ouest de la France). Partie 2. Cossmanniana, 6, 1-68.

Lozouet, P., \& Galindo, L. A. (2015). Resolution of the confused classification of some Miocene Nassariidae, and reappraisal of their paleobiodiversity on the French Atlantic seaboard (Gastropoda: Neogastropoda). Archiv Für Molluskenkunde: International Journal of Malacology, 144, 31-50. https://doi.org/10.1127/arch.moll/1869-0963/144/031-050

Maddison, W. P., \& Maddison, D. R. (2018). Mesquite: a modular system for evolutionary analysis. Version 3.6. http://www.mesquiteproject.org

Manganelli, G., Spadini, V., \& Martini, I. (2010) Rediscovery of an enigmatic Euro-Mediterranean Pliocene nassariid species: Nassarius crassiusculus Bellardi, 1882 (Gastropoda: Nassariidae). Bollettino della Società Paleontologica Italiana, 49, 195-202.

Miller, M., Pfeiffer, W., \& Schwartz, T. (2010). Creating the CIPRES Science Gateway for inference of large phylogenetic trees. Proceedings of the Gateway Computing Environments Workshop (GCE), New Orleans, LA, pp. 1-8.

Modica, M.V., Gorson, J., Fedosov, A.E., Malcolm, G., Terryn, Y., Puillandre, N. \& Holford, M. (2020) Macroevolutionary analyses suggest that environmental factors, not venom apparatus, play key role in Terebridae marine snail diversification. Systematic Biology, 69, 413-430. https://doi.org/10.1093/sysbio/syz059

MolluscaBase (2020a) Nassariidae Iredale, 1916 (1835). Accessed through: World Register of Marine Species. Retrieved from: 
http://www.marinespecies.org/aphia.php?p=taxdetails\&id=151 Accessed 2020-04-10.

945

946

947

948

949

950

951

952

953

954

955

956

957

958

959

960

961

962

963

964

965

966

967

968

969

970

MolluscaBase (2020b). MolluscaBase. Nassarius Duméril, 1805. Accessed through: World Register of Marine Species. Retrieved from: http://www.marinespecies.org/aphia.php?p=taxdetails\&id=138235 on 2020-07-18

MolluscaBase (2020c). Tritia Risso, 1826. Accessed through: World Register of Marine Species. Retrieved from: http://www.marinespecies.org/aphia.php?p=taxdetails\&id=246140 Accessed 2020-04-10.

Moreno, D. \& Templado, J. (1994). The species complex “Nassarius cuvierii - N. unifasciatus" (Gastropoda, Nassariidae) in the SE of Spain. Iberus, 12, 33-47.

Morton, B. (2011) Behaviour of Nassarius bicallosus (Caenogastropoda) on a northwestern Western Australian surf beach with a review of feeding in the Nassariidae. Molluscan Research, 31, 89-94

Nekhaev, I. O. (2014). Marine shell-bearing Gastropoda of Murman (Barents Sea): an annotated check-list. Ruthenica, 24, 75-121.

Nguyen, L. T., Schmidt, H. A., Von Haeseler, A., \& Minh, B. Q. (2015). IQ-TREE: a fast and effective stochastic algorithm for estimating maximum-likelihood phylogenies. Molecular Biology and Evolution, 32, 268-274. https://doi.org/10.1093/molbev/msu300

Ojala, D., Montoya J., \& Attardi, G. (1981) tRNA punctuation model of RNA processing in human mitochondria. Nature, 290, 470-474.

Okay, A. I., Zattin, M., \& Cavazza, W. (2010). Apatite fission-track data for the Miocene Arabia-Eurasia collision. Geology, 38, 35-38. https://doi.org/10.1130/G30234.1

Oliverio, M. (1996). Contrasting developmental strategies and speciation in NE Atlantic prosobranchs: a preliminary analysis. Origin and Evolutionary Radiation of the Mollusca, 22, 261-266.

Osca, D., Templado, J., \& Zardoya, R. (2015). Caenogastropod mitogenomics. Molecular Phylogenetics and Evolution, 93, 118-128. https://doi.org/10.1016/j.ympev.2015.07.011

Ozawa, T., Köhler, F., Reid, D. G., \& Glaubrecht, M. (2009). Tethyan relicts on continental 
coastlines of the northwestern Pacific Ocean and Australasia: molecular phylogeny and fossil record of batillariid gastropods (Caenogastropoda, Cerithioidea). Zoologica Scripta, 38, 503525. https://doi.org/10.1111/j.1463-6409.2009.00390.x

Pallary, P. (1906). Diagnoses de nouvelles coquilles du Maroc. Oran, privately printed 3 pp.

Patarnello, T., Volckaert, F. A., \& Castilho, R. (2007). Pillars of Hercules: is the AtlanticMediterranean transition a phylogeographical break? Molecular ecology, 16, 4426-4444. https://doi.org/10.1111/j.1365-294X.2007.03477.x

Ponder, W. F., \& Lindberg, D. R. (1997). Towards a phylogeny of gastropod molluscs: an analysis using morphological characters. Zoological Journal of the Linnean Society, 119, 83-265. ttps://doi.org/10.1111/j.1096-3642.1997.tb00137.x

Ponder, W. F., \& Lindberg, D. R. (2019). Biology and evolution of the Mollusca. Boca Raton, FL. CRC press.

Pu, C., Li, H., Zhu, A., Chen, Y., Zhao, Y., \& Zhan, A. (2017). Phylogeography in Nassarius mud snails: Complex patterns in congeneric species. PLoS ONE, 12, e0180728. https://doi.org/10.1371/ journal.pone.0180728

Reid, D. G., Rumbak, E., \& Thomas, R. H. (1996). DNA, morphology and fossils: phylogeny and evolutionary rates of the gastropod genus Littorina. Philosophical Transactions of the Royal Society of London B, 351, 877-895. https://doi.org/10.1098/rstb.1996.0082

Rodríguez-Flores, P.C., Buckley, D., MacPherson, E., Corbari, L., \& Machordom, A. (2020) Deep-sea squat lobster biogeography (Munidopsidae: Leiogalathea) unveils Tethyan vicariance and evolutionary patterns shared by shallow-water relatives. Zoologica Scripta, 49, 340-356. https://doi.org/10.1111/zsc.12414

Rolán E. (1984). Descripción de una nueva especie del género Hinia Leach in Gray, 1847 (Mollusca, Gastropoda) procedente del Archipiélago de Cabo Verde. Bolletino Malacologico 29, 167-174.

Rolán E., Luque, A.A. (1994). Nassarius reticulatus (Linnaeus, 1758) y Nassarius nitidus (Jeffreys, 1867) (Gastropoda, Nassariidae), dos especies válidas de los mares de Europa. Iberus, 12, 5976. 
Rolán, E., \& Hernandez, J. M. (2005). The West African species of the group Nassarius denticulatus (Mollusca, Neogastropoda), with the description of a new species. Journal of Conchology, 38, 499-511.

Ronquist, F., \& Huelsenbeck, J. P. (2003). MrBayes 3: Bayesian phylogenetic inference under mixed models. Bioinformatics, 19, 1572-1574. https://doi.org/10.1093/bioinformatics/btg180

Rosenberg, G. (2009). Malacolog 4.1.1: a database of Western Atlantic marine Mollusca. [www database (version 4.1.1)]. http://www.malacolog.org/.

Roux, C., Fraisse, C., Romiguier, J., Anciaux, Y., Galtier, N., \& Bierne, N. (2016). Shedding light on the grey zone of speciation along a continuum of genomic divergence. PLoS biology, 14, e2000234. https://doi.org/ 10.1371/journal.pbio.2000234

Schattner, P., Brooks, A. N., \& Lowe, T. M. (2005). The tRNAscan-SE, snoscan and snoGPS web servers for the detection of tRNAs and snoRNAs. Nucleic Acids Research, 33, W686-W689. https://doi.org/10.1093/nar/gki366

Schmieder, R., \& Edwards, R. (2011). Quality control and preprocessing of metagenomic datasets. Bioinformatics, 27, 863-864. https://doi.org/10.1093/bioinformatics/btr026

Schwarz, G. (1978). Estimating the dimension of a model. The Annals of Statistics, 6, 461-464.

Shank, A.L. 2009. Pelagic larval duration and dispersal distance revisited. Biological Bulletin, 216, 373-385.

Shuto, T. (1974). Larval ecology of prosobranch gastropods and its bearing on biogeography and paleontology. Lethaia, 7, 239-256.

Simison, W. B., Lindberg, D. R., \& Boore, J. L. (2006). Rolling circle amplification of metazoan mitochondrial genomes. Molecular Phylogenetics and Evolution, 39, 562-567. https://doi.org/10.1016/j.ympev.2005.11.006

Simone, L. R. L., \& Pastorino, G. (2014). Comparative Morphology of Dorsanum miran and Bullia granulosa from Morocco (Mollusca: Caenogastropoda: Nassariidae). African Invertebrates, 55, 125-142. https://doi.org/10.5733/afin.055.0107

Strathmann, R. R. (1978). The evolution and loss of feeding larval stages of marine invertebrates. 
Strong, E. E., Galindo, L. A., \& Kantor, Y. I. (2017). Quid est Clea helena? Evidence for a previously unrecognized radiation of assassin snails (Gastropoda: Buccinoidea: Nassariidae). PeerJ, 5, e3638. https://doi.org/10.7717/peerj.3638

Taylor, J. D., Morris, N. J., \& Taylor, C. N. (1980). Food specialization and the evolution of predatory prosobranch gastropods. Palaentology, 23, 375-409.

Thorson, G. (1950). Reproductive and larval ecology of marine bottom invertebrates. Biological Reviews, 25, 1-45.

Tracey, S., Todd, J. A., \& Erwin, D. H. (1993). Mollusca: Gastropoda. In M. J. Benton (Ed.). The Fossil Record 2 (pp. 131-167). London, Chapman \& hall.

Uribe, J. E., Puillandre, N., \& Zardoya, R. (2017). Beyond Conus: phylogenetic relationships of Conidae based on complete mitochondrial genomes. Molecular Phylogenetics and Evolution, 107, 142-151. https://doi.org/10.1016/j.ympev.2016.10.008

Uribe, J.E., Williams, S. T., Templado, J., Buge, B. \& Zardoya, R. (2017b) Phylogenetic relationships of Mediterranean and North-East Atlantic Cantharidinae and notes on Stomatellinae (Vetigastropoda: Trochidae). Molecular Phylogenetics and Evolution, 107, 6479. https://doi.org/10.1016/j.ympev.2016.10.009.

Van Dingenen F, Ceulemans L, Landau M \& da Silva C M. (2015).The family Nassariidae from the late Neogene of northwestern France. Cainozoic Research, 15(1-2), 75-122.

Xia, X. (2013). DAMBE5: A comprehensive software package for data analysis in molecular biology and evolution. Molecular Biology and Evolution, 30, 1720-1728. https://doi.org/10.1093/molbev/mst064

Yang, Y., Li, Q., Kong, L., \& Yu, H. (2018). Comparative mitogenomic analysis reveals cryptic species in Reticunassa festiva (Neogastropoda: Nassariidae). Gene, 662, 88-96. https://doi.org/10.1016/j.gene.2018.04.001

Yang, Y., Li, Q., Kong, L., \& Yu, H. (2019). Mitogenomic phylogeny of Nassarius (Gastropoda: Neogastropoda). Zoologica Scripta, 48, 302-312. https://doi.org/10.1111/zsc.12343 
1052 Yang, Y., Liu, H., Qi, L., Kong, L., \& Li, Q. (2020). Complete Mitochondrial Genomes of Two 1053 Toxin-Accumulated Nassariids (Neogastropoda: Nassariidae: Nassarius) and Their Implication 1054 for Phylogeny. International Journal of Molecular Sciences, 21, 3545.

1055 https://doi.org/10.3390/ijms21103545

1056 Zachos, J. C., Shackleton, N.J., Revenaugh, J.S., Pälike, H. \& Flower, B. P. (2001), Climate response to orbital forcing across the Oligocene-Miocene boundary. Science, 292, 274- 278. https://doi.org/10.1126/science.1058288

1059 Zhang, A. J., \& You, Z. J. (2009). Molecular phylogenetic relationships of some species of 1060 Nassarius (Gastropoda, Prosobranchia, Neogastropoda, Nassariidae) based on 16S rRNA fragment sequence. Acta Zootaxonomica Sinica, 33, 549-552. 


\section{Figure captions}

Figure 1. Gene order of Tritia mitogenomes. All newly sequenced mt genomes shared identical genome organization. The genes encoded in the major and minor strands are shown in the top and bottom rows, respectively. Genes encoding for proteins (blue), rRNAs (pink), and tRNAs (red) are depicted with different colors. The relative positions of the primers for long PCR are shown.

Figure 2. Phylogenetic relationships within Nassariinae based on the nucleotide sequences of 13 protein-coding genes plus two rRNA genes. The Bayesian inference (BI) phylogram is shown. The non-nassariinae Anentome sp. was used as outgroup. The three Northeast clades are indicated. Numbers at nodes are statistical support values for ML (bootstrap proportions in percentage)/BI (posterior probabilities). Solid red circles represent nodes with maximum support values. The bar indicates substitutions per site. Additional Tritia species whose relative phylogenetic positions were resolved in Galindo et al. (2016) but were not included in this study are shown with a dashed line. Ventral images of the voucher specimens are shown.

Figure 3. Ancestral character state reconstruction of Tritia protoconch (paucispiral versus multispiral) using the ML model Mk1 in Mesquite. Pie charts represent the statistical support at every node.

Figure 4. Chronogram with age estimates of major divergence events within Nassariinae based on the nucleotide sequences of the concatenated mitochondrial protein coding genes, and using Bayesian relaxed dating methods (BEAST). Horizontal bars represent 95\% credible intervals of relevant nodes, and calibration constraints are indicated with an asterisk on the corresponding nodes. Dates (and highest posterior density intervals, HPD) are in millions of years. Geological epochs are indicated. 


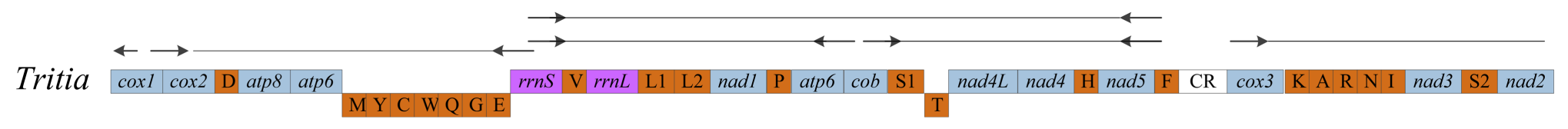




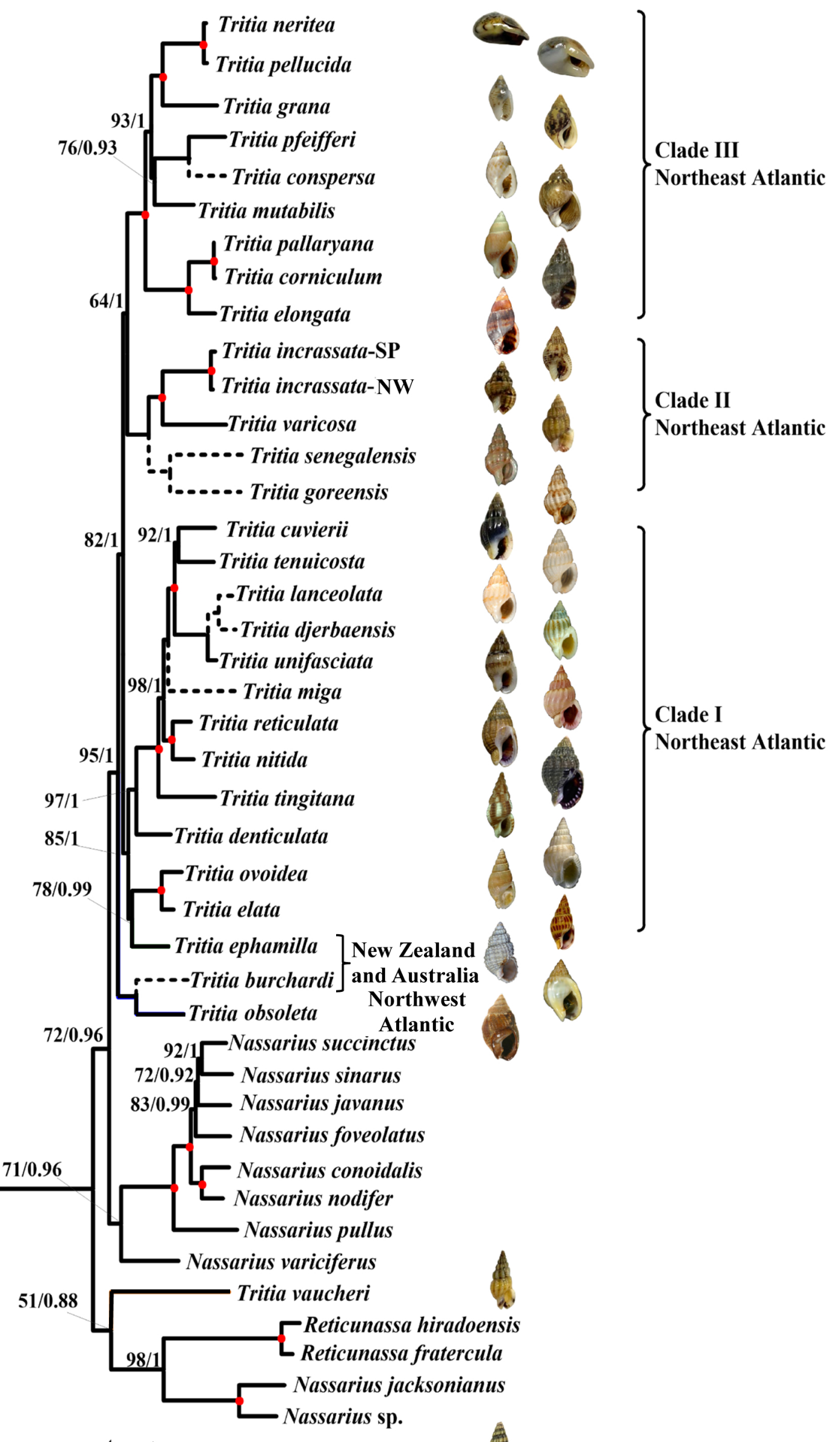

Anentome sp. 


\section{Tritia neritea}

Tritia pellucida

Tritia grana

Tritia pfeifferi

Tritia mutabilis

Tritia pallaryana

Tritia corniculum

Tritia elongata

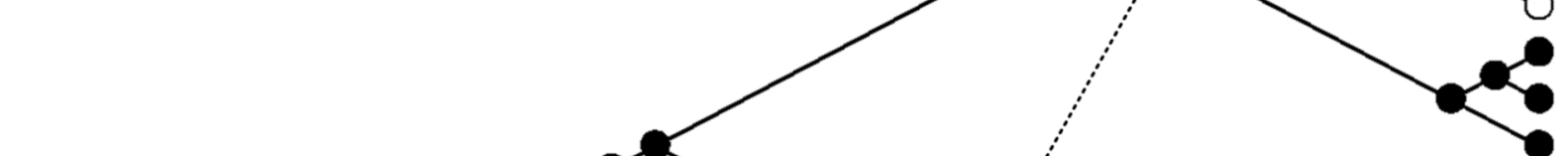

Tritia incrassata-SP

Tritia incrassata-NW

Tritia varicosa
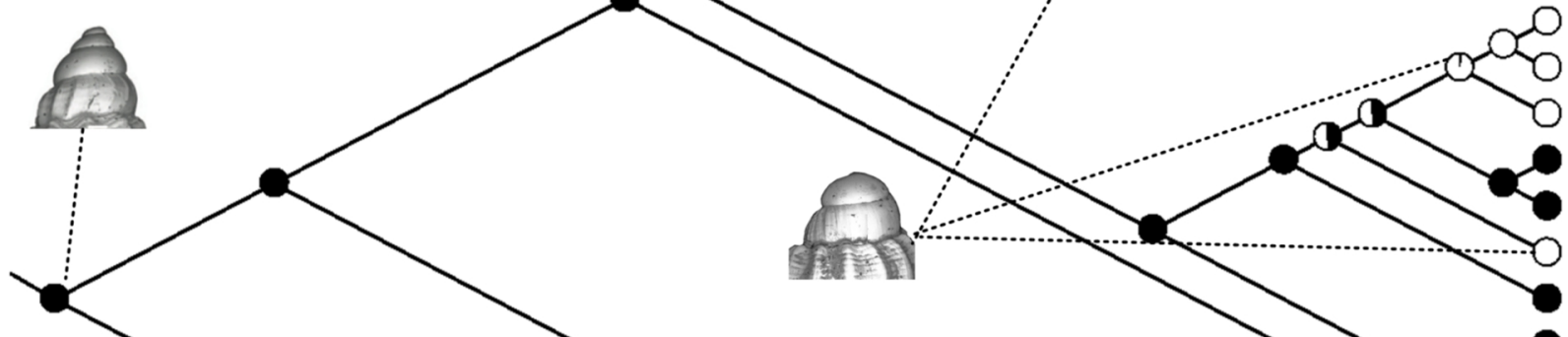

Tritia cuvierii

Tritia tenuicosta

Tritia unifasciata

Tritia reticulata

Tritia nitida

Tritia tingitana

Tritia denticulata

Tritia ovoidea

Tritia elata

Tritia ephamilla

Ilyanassa obsoleta

Nassarius succinctus

Nassarius sinarus

Nassarius javanus

Nassarius foveolatus

Nassarius conoidalis

Nassarius nodifer

Nassarius pullus

Nassarius variciferus

"Tritia" vaucheri

Reticunassa hiradoensis

Reticunassa fratercula

Nassarius jacksonianus

Nassarius sp. 
Table 1. Mitochondrial (mt) genomes analyzed in this study.

\begin{tabular}{|c|c|c|c|c|c|c|c|}
\hline \multicolumn{8}{|l|}{ New mt genomes } \\
\hline Species & Location & Collector & No. reads & Coverage $(\mathrm{x})$ & Length (bp) & Genbank Acc. No. & Voucher \\
\hline Tritia corniculum & $\begin{array}{l}\text { Ilha da Armona, } \\
\text { Portugal }\end{array}$ & CLMA & 34502 & 75 & 15114 & MT755650 & MNCN:ADN: 118970 \\
\hline Tritia cuvierii & $\begin{array}{l}\text { Cabo de Palos, } \\
\text { Spain }\end{array}$ & JT & 36582 & 306 & 15185 & MT755651 & MNCN:ADN: 118971 \\
\hline Tritia grana & $\begin{array}{l}\text { Cabo de Palos, } \\
\text { Spain }\end{array}$ & JT & 40296 & 131 & 15198 & MT762151 & MNCN:ADN: 118972 \\
\hline Tritia incrassata-SP & $\begin{array}{l}\text { Cabo de Palos, } \\
\text { Spain }\end{array}$ & JT & 30800 & 53 & 15159 & MT762153 & MNCN:ADN: 118973 \\
\hline Tritia incrassata -NW & Bergen, Norway & David Osca & 38716 & 151 & 15170 & MT762152 & MNCN:ADN: 118974 \\
\hline Tritia mutabilis & $\begin{array}{l}\text { Market, Madrid, } \\
\text { Spain }\end{array}$ & YY & 40182 & 250 & 15148 & MT762154 & MNCN:ADN: 118975 \\
\hline Tritia neritea & Vigo, Spain & SA & 35082 & 216 & 15179 & MT762155 & MNCN:ADN: 118976 \\
\hline Tritia pellucida & Mar Menor, Spain & JT & 40234 & 317 & 15175 & MT768039 & MNCN:ADN: 118977 \\
\hline Tritia pfeifferi & $\begin{array}{l}\text { Praia dos Cavacos, } \\
\text { Portugal }\end{array}$ & CLMA & 43804 & 76 & 15142 & MT768040 & MNCN:ADN: 118978 \\
\hline Tritia unifasciata & Mar Menor, Spain & JT & 43288 & 322 & 15168 & MT768043 & MNCN:ADN: 118979 \\
\hline Tritia vaucheri & Isla Canela, Spain & CLMA & 58170 & 83 & 15153 & MT768044 & MNCN:ADN: 118980 \\
\hline Tritia denticulata & Candelaria, Spain & - & 2142656 & 19059 & 15167 & MT755652 & MNHN-IM-2009-21546 \\
\hline Tritia ephamilla & $\begin{array}{l}\text { Kermadec Ridge, } \\
\text { New Zealand }\end{array}$ & - & 1849562 & 14802 & 15157 & MT755654 & MNHN-IM-2009-24014 \\
\hline Tritia pallaryana & $\begin{array}{l}\text { Golfe de Gabès, } \\
\text { Tunisie }\end{array}$ & Chrifa Aissaoui & 2515502 & 21974 & 15144 & MT762157 & MNHN-IM-2009-30939 \\
\hline Tritia tenuicosta & $\begin{array}{l}\text { Golfe de Gabès, } \\
\text { Tunisie }\end{array}$ & Chrifa Aissaoui & 2494246 & 19378 & 15169 & MT768042 & MNHN-IM-2013-31865 \\
\hline Tritia elongata & Errimel, Tunisie & Chrifa Aissaoui & 2133232 & 18698 & 15145 & MT755653 & MNHN-IM-2013-32570 \\
\hline Tritia nitida & Vigo, Spain & Samuel Abalde & 2415740 & 21498 & 15157 & MT762156 & MNCN:ADN: 118981 \\
\hline Tritia varicosa & $\begin{array}{l}\text { Ponta da Piedade, } \\
\text { Portugal }\end{array}$ & CLMA & 2765768 & 23350 & 15142 & MT768041 & MNCN:ADN: 118982 \\
\hline Tritie elata & $\begin{array}{l}\text { Ponta da Piedade, } \\
\text { Portugal }\end{array}$ & CLMA & 2493798 & 21897 & 15167 & MT768045 & MNCN:ADN: 118983 \\
\hline Tritia tingitana & Isla de Tarifa, Spain & Serge Gofas & - & - & 13337 & MW194096 & MNCN:ADN: 118984 \\
\hline Tritia ovoidea & $\begin{array}{l}\text { Cañón de Carchuna, } \\
\text { Spain }\end{array}$ & Serge Gofas & - & - & 14889 & MW194095 & MNCN:ADN: 118985 \\
\hline Anentome sp. & $\begin{array}{l}\text { Aquarium market, } \\
\text { Madrid, Spain }\end{array}$ & YY & 2528802 & 19514 & 15069 & MT755649 & MNCN:ADN: 118986 \\
\hline
\end{tabular}




\begin{tabular}{llll}
\hline Species & Length (bp) & Accession No. & Reference \\
\hline Tritia obsoleta & 15263 & DQ238598 & Simison, Lindberg, \& Boore, 2006 \\
Tritia reticulata & 15271 & EU827201 & Cunha, Grande, \& Zardoya, 2009 \\
Nassarius variciferus & 15269 & KM603509 & Yang, Li, Kong, \& Yu, 2018 \\
Nassarius succinctus & 15329 & KT768016 & Yang, Li, Kong, \& Yu, 2019 \\
Nassarius nodifer & 15337 & KT818617 & Yang, Li, Kong, \& Yu, 2019 \\
Nassarius conoidalis & 15332 & KT826694 & Yang, Li, Kong, \& Yu, 2019 \\
Nassarius pullus & 15278 & KT900947 & Yang, Li, Kong, \& Yu, 2019 \\
Nassarius sinarus & 15325 & MH346208 & Yang, Li, Kong, \& Yu, 2019 \\
Nassarius foveolatus & 15343 & MH346209 & Yang, Li, Kong, \& Yu, 2019 \\
Nassarius javanus & 15325 & MH346210 & Yang, Li, Kong, \& Yu, 2019 \\
Reticunassa fratercula & 15174 & KT826695 & Yang, Li, Kong, \& Yu, 2018 \\
Reticunassa hiradoensis & 15194 & MG744569 & Yang, Li, Kong, \& Yu, 2018 \\
Nassarius jacksonianus & 15234 & MH346212 & Yang, Li, Kong, \& Yu, 2019 \\
Nassarius sp. & 15240 & MH346211 & Yang, Li, Kong, \& Yu, 2019 \\
\hline
\end{tabular}

Nassarius sp.

15240

MH346211 Yang, Li, Kong, \& Yu, 2019 
Table S1. Standard and Long PCR primers for Tritia mitogenomes.

\begin{tabular}{lll}
\hline Tritia corniculum & \multicolumn{2}{c}{ Sequenced by Allgenetics, with a buccinoid species in the same library } \\
\hline $\begin{array}{l}\text { Long PCR } \\
\text { Primer }\end{array}$ & Sequence 5'-3' & Fragment (bp) \\
\hline cox1laF & AAYATRCGATGACGAGGRATRCARTTTGA & cox1-rrnS (4K) \\
12SlaR & ATAGGCTGCACCTTGATCTGACGTYTT & \\
\hline 12SlaF & CAGTTTGTATACCGTCGTCGTCAGGT & rrnS-cob (4.5K) \\
cobla2R & GGRTTAGCWGGRATAAARTTYTCWGGRTC & \\
\hline cobla2F & CCYTGAGGTCARATATCYTTYTGAGGRGC & cob-trnF (4.3K) \\
trnF-R & CACCCTAGCATCTTCAGTGCTATGCTCT & \\
\hline cox3la2F & ATGGCRCGNAATCCTTTTCATTTAGTWGARTT & cox3-cox1 (2.5K) \\
cox1laR & CGAGGAAAAGCYATRTCAGGAGC & \\
\hline Primer Link cox1 & Fragment (bp) \\
Primer & Sequence 5'-3' & cox1 (400) \\
\hline COI-tritiaF & ACWGCYCAYGCTTTYGTAATAAT & \\
COI-tritiaR & TGYATNCCTCGTCATCGYATRTT & \\
\hline
\end{tabular}

\begin{tabular}{lll}
$\begin{array}{ll}\text { Tritia cuvierii } \\
\text { Long PCR } \\
\text { Primer }\end{array}$ & Sequenced by Allgenetics, in a whole library & \\
\hline cox1laF & Sequence 5'-3' & Fragment (bp) \\
12SlaR & AAYATRCGATGACGAGGRATRCARTTTGA & cox1-rrnS (4K) \\
\hline 12SlaF & CAGTGCTGCACCTTGATCTGACGTYTT & \\
cobla2R & GGRTTAGCWGGRATAAARTTYTCWGGRTC & rrnS-cob (4.5K) \\
\hline cobla2F & CCYTGAGGTCARATATCYTTYTGAGGRGC & cob-trnF (4.3K) \\
trnF-R & CACCCTAGCATCTTCAGTGCTATGCTCT & \\
\hline cox3la2F & ATGGCRCGNAATCCTTTTCATTTAGTWGARTT & cox3-cox1 (2.5K) \\
cox1laR & CGAGGAAAAGCYATRTCAGGAGC & \\
\hline Primer Link cox1 & \\
Primer & Sequence 5'-3' & Fragment (bp) \\
\hline LCO1490 F & GGTCAACAAATCATAAAGATATTGG & cox1 (709) \\
HCO2198 R & TTAACTTCAGGGTGACCAAAAAATCA & \\
\hline
\end{tabular}

\begin{tabular}{lll}
$\begin{array}{ll}\text { Tritia grana } \\
\text { Long PCR } \\
\text { Primer }\end{array}$ & Sequenced by Allgenetics, with a cone species in the same library \\
\hline $\begin{array}{l}\text { cox1laF } \\
\text { 12SlaR }\end{array}$ & AAYATRCGATGACGAGGRATRCARTTTGA & Fragment (bp) \\
\hline $\begin{array}{l}\text { 12SlaF } \\
\text { cobla2R }\end{array}$ & ATAGGCTGCACCTTGATCTGACGTYTT & \\
\hline $\begin{array}{l}\text { cobla2F } \\
\text { trnF-R }\end{array}$ & GGRTTTGTATACCGTCGTCGTCAGGT & rrnS-cob (4.5K) \\
\hline
\end{tabular}




\begin{tabular}{lll}
\hline $\begin{array}{l}\text { cox3la2F } \\
\text { cox1laR }\end{array}$ & ATGGCRCGNAATCCTTTTCATTTAGTWGARTT & cox3-cox1 (2.5K) \\
\hline \multicolumn{2}{l}{ Primer Link $\boldsymbol{c o x} \mathbf{1}$} & \\
Primer & Sequence 5'-3' & Fragment (bp) \\
\hline LCO1490 F & GGTCAACAAATCATAAAGATATTGG & cox1 (709) \\
HCO2198 R & TTAACTTCAGGGTGACCAAAAAATCA & \\
\hline
\end{tabular}

Tritia incrassata-sp Sequenced by Allgenetics, with a cone species in the same library

\begin{tabular}{|c|c|c|}
\hline \multicolumn{3}{|l|}{ Long PCR } \\
\hline Primer & Sequence 5'-3' & Fragment (bp) \\
\hline cox1laF & AAYATRCGATGACGAGGRATRCARTTTGA & $\operatorname{cox} 1-r r n S(4 \mathrm{~K})$ \\
\hline 12SlaR & ATAGGCTGCACCTTGATCTGACGTYTT & \\
\hline 12SlaF & CAGTTTGTATACCGTCGTCGTCAGGT & $r r n S-c o b(4.5 \mathrm{~K})$ \\
\hline cobla2R & GGRTTAGCWGGRATAAARTTYTCWGGRTC & \\
\hline cobla2F & CCYTGAGGTCARATATCYTTYTGAGGRGC & cob-trnF (4.3K) \\
\hline $\operatorname{trnF-R}$ & CACCCTAGCATCTTCAGTGCTATGCTCT & \\
\hline cox3la2F & ATGGCRCGNAATCCTTTTCATTTAGTWGARTT & $\operatorname{cox} 3-\operatorname{cox} 1(2.5 \mathrm{~K})$ \\
\hline cox1laR & CGAGGAAAAGCYATRTCAGGAGC & \\
\hline
\end{tabular}

\begin{tabular}{lll}
\hline \multicolumn{2}{l}{ Primer Link cox 1} & \\
Primer & Sequence 5'-3' & Fragment (bp) \\
\hline COINassaF & TCTACAAATCATAAAGACATTGG & $\operatorname{cox1}(700)$ \\
COINassaR & ACYTCAGGATGACCAAARAATCA & \\
\hline
\end{tabular}

Tritia incrassata-nw Sequenced by Allgenetics, in a whole library

\begin{tabular}{|c|c|c|}
\hline \multicolumn{3}{|l|}{ Long PCR } \\
\hline Primer & Sequence 5'-3' & Fragment (bp) \\
\hline cox1laF & AAYATRCGATGACGAGGRATRCARTTTGA & cox1-rrnS (4K) \\
\hline 12SlaR & ATAGGCTGCACCTTGATCTGACGTYTT & \\
\hline 12SlaF & CAGTTTGTATACCGTCGTCGTCAGGT & $r r n S-c o b(4.5 \mathrm{~K})$ \\
\hline cobla2R & GGRTTAGCWGGRATAAARTTYTCWGGRTC & \\
\hline cobla2F & CCYTGAGGTCARATATCYTTYTGAGGRGC & cob-trnF (4.3K) \\
\hline $\operatorname{trnF-R}$ & CACCCTAGCATCTTCAGTGCTATGCTCT & \\
\hline cox3la2F & ATGGCRCGNAATCCTTTTCATTTAGTWGARTT & $\operatorname{cox} 3-\operatorname{cox} 1(2.5 \mathrm{~K})$ \\
\hline cox1laR & CGAGGAAAAGCYATRTCAGGAGC & \\
\hline \multicolumn{3}{|c|}{ Primer Link cox1 } \\
\hline Primer & Sequence 5'-3' & Fragment (bp) \\
\hline COINassaF & TCTACAAATCATAAAGACATTGG & $\operatorname{cox} 1(700)$ \\
\hline COINassaR & ACYTCAGGATGACCAAARAATCA & \\
\hline Tritia mutabilis & Sequenced by Allgenetics, in a whole library & \\
\hline \multicolumn{3}{|l|}{ Long PCR } \\
\hline Primer & Sequence 5'-3' & Fragment (bp) \\
\hline cox1laF & AAYATRCGATGACGAGGRATRCARTTTGA & cox1-rrnS (4K) \\
\hline 12SlaR & ATAGGCTGCACCTTGATCTGACGTYTT & \\
\hline
\end{tabular}




\begin{tabular}{lll}
\hline $\begin{array}{l}\text { 12SlaF } \\
\text { cobla2R }\end{array}$ & CAGTTTGTATACCGTCGTCGTCAGGT & rrnS-cob (4.5K) \\
\hline cobla2F & CGRTTAGCWGGRATAAARTTYTCWGGRTC & \\
trnF-R & CACCCTAGCATCTTCAGTGCTATGCTCT & cob-trnF (4.3K) \\
\hline cox3la2F & ATGGCRCGNAATCCTTTTCATTTAGTWGARTT & cox3-cox1 (2.5K) \\
cox1laR & CGAGGAAAAGCYATRTCAGGAGC & \\
\hline
\end{tabular}

\begin{tabular}{lll}
\hline \multicolumn{2}{l}{ Primer Link $\operatorname{cox} \mathbf{1}$} & \\
Primer & Sequence 5'-3' & Fragment (bp) \\
\hline COINassaF & TCTACAAATCATAAAGACATTGG & cox1 (700) \\
COINassaR & ACYTCAGGATGACCAAARAATCA & \\
\hline
\end{tabular}

\begin{tabular}{lll} 
Tritia neritea & Sequenced by Allgenetics, in a whole library & \\
\hline $\begin{array}{l}\text { Long PCR } \\
\text { Primer }\end{array}$ & Sequence 5'-3' & Fragment (bp) \\
\hline cox1laF & AAYATRCGATGACGAGGRATRCARTTTGA & cox1-rrnS (4K) \\
12SlaR & ATAGGCTGCACCTTGATCTGACGTYTT & \\
\hline 12 SlaF & CAGTTTGTATACCGTCGTCGTCAGGT & rrnS-cob (4.5K) \\
cobla2R & GGRTTAGCWGGRATAAARTTYTCWGGRTC & \\
\hline cobla2F & CCYTGAGGTCARATATCYTTYTGAGGRGC & cob-trnF (4.3K) \\
trnF-R & CACCCTAGCATCTTCAGTGCTATGCTCT & \\
\hline cox3la2F & ATGGCRCGNAATCCTTTTCATTTAGTWGARTT & cox3-cox1 (2.5K) \\
cox1laR & CGAGGAAAAGCYATRTCAGGAGC & \\
\hline
\end{tabular}

\begin{tabular}{lll}
\hline \multicolumn{2}{l}{ Primer Link cox1 } & \\
Primer & Sequence 5'-3' & Fragment (bp) \\
\hline LCO1490 F & GGTCAACAAATCATAAAGATATTGG & cox1 (709) \\
HCO2198 R & TTAACTTCAGGGTGACCAAAAAATCA & \\
\hline
\end{tabular}

\begin{tabular}{lll} 
Tritia pellucida & Sequenced by Allgenetics, in a whole library & \\
\hline $\begin{array}{l}\text { Long PCR } \\
\text { Primer }\end{array}$ & Sequence 5'-3' & Fragment (bp) \\
\hline $\begin{array}{l}\text { cox1laF } \\
\text { 12SlaR }\end{array}$ & AAYATRCGATGACGAGGRATRCARTTTGA & cox1-rrnS (4K) \\
\hline 12SlaF & CAGGGCTGCACCTTGATCTGACGTYTT & \\
cobla2R & GGRTTAGCWGGRATAAARTTYTCWGGRTC & \\
\hline cobla2F & CCYTGAGGTCARATATCYTTYTGAGGRGC & \multirow{2}{*}{ cob-trnF (4.3K) } \\
trnF-R & CACCCTAGCATCTTCAGTGCTATGCTCT & \\
\hline cox3la2F & ATGGCRCGNAATCCTTTTCATTTAGTWGARTT & cox3-cox1 (2.5K) \\
cox1laR & CGAGGAAAAGCYATRTCAGGAGC & \\
\hline Primer Link cox1 & \\
Primer & Sequence 5'-3' & Fragment (bp) \\
\hline LCO1490 F & GGTCAACAAATCATAAAGATATTGG & cox1 (709) \\
HCO2198 R & TTAACTTCAGGGTGACCAAAAAATCA & \\
\hline
\end{tabular}

Tritia pfeifferi Sequenced by Allgenetics, with a buccinoid species in the same library 


\begin{tabular}{lll}
\hline $\begin{array}{l}\text { Long PCR } \\
\text { Primer }\end{array}$ & Sequence 5'-3' & Fragment (bp) \\
\hline cox1laF & AAYATRCGATGACGAGGRATRCARTTTGA & cox1-rrnS (4K) \\
12SlaR & ATAGGCTGCACCTTGATCTGACGTYTT & \\
\hline $\begin{array}{l}\text { 12SlaF } \\
\text { cobla2R }\end{array}$ & CAGTTTGTATACCGTCGTCGTCAGGT & rrnS-cob (4.5K) \\
\hline cobla2F & CGRTTAGCWGGRATAAARTTYTCWGGRTC & \\
trnF-R & CACCCTAGCATCTTCAGTGCTATGCTCT & cob-trnF (4.3K) \\
\hline cox3la2F & ATGGCRCGNAATCCTTTTCATTTAGTWGARTT & cox3-cox1 (2.5K) \\
cox1laR & CGAGGAAAAGCYATRTCAGGAGC & \\
\hline Primer Link cox1 & & \\
Primer & Sequence 5'-3' & Fragment (bp) \\
\hline $\begin{array}{l}\text { COINassaF } \\
\text { COINassaR }\end{array}$ & TCTACAAATCATAAAGACATTGG & cox1 (700) \\
\hline & ACYTCAGGATGACCAAARAATCA & \\
Tritia unifascita & Sequenced by Allgenetics, in a whole library & \\
\hline $\begin{array}{l}\text { Long PCR } \\
\text { Primer }\end{array}$ & Sequence 5'-3' & Fragment (bp) \\
\hline cox1laF & AAYATRCGATGACGAGGRATRCARTTTGA & cox1-rrnS (4K) \\
12SlaR & ATAGGCTGCACCTTGATCTGACGTYTT & \\
\hline $\begin{array}{l}\text { 12SlaF } \\
\text { cobla2R }\end{array}$ & CAGTTTGTATACCGTCGTCGTCAGGT & rrnS-cob (4.5K) \\
\hline cobla2F & GGRTTAGCWGGRATAAARTTYTCWGGRTC & \\
trnF-R & CCYTGAGGTCARATATCYTTYTGAGGRGC & cob-trnF (4.3K) \\
\hline cox3la2F & ATGGCRCGNAATCCTTTTCATTTAGTWGARTT & cox3-cox1 (2.5K) \\
cox1laR & CGAGGAAAAGCYATRTCAGGAGC & \\
\hline $\begin{array}{l}\text { Primer Link cox1 } \\
\text { Primer }\end{array}$ & Sequence 5'-3' & \\
\hline LCO1490 F & GGTCAACAAATCATAAAGATATTGG & \\
HCO2198 R & TTAACTTCAGGGTGACCAAAAAATCA & \\
\hline & & \\
\hline
\end{tabular}

\begin{tabular}{lll} 
Tritia vaucheri & Sequenced by Allgenetics, with a buccinoid species in the same library \\
\hline $\begin{array}{l}\text { Long PCR } \\
\text { Primer }\end{array}$ & Sequence 5'-3' & Fragment (bp) \\
\hline $\begin{array}{l}\text { cox1laF } \\
\text { 12SlaR }\end{array}$ & AAYATRCGATGACGAGGRATRCARTTTGA & cox1-rrnS (4K) \\
\hline 12SlaF & ATAGGCTGCACCTTGATCTGACGTYTT & \\
cobla2R & GGRTTTGTATACCGTCGTCGTCAGGT & rrnS-cob (4.5K) \\
\hline cobla2F & CCYTGAGGTCARATATCYTTYTGAGGRGC & \multirow{2}{*}{ cob-trnF (4.3K) } \\
trnF-R & CACCCTAGCATCTTCAGTGCTATGCTCT & \\
\hline cox3la2F & ATGGCRCGNAATCCTTTTCATTTAGTWGARTT & cox3-cox1 (2.5K) \\
cox1laR & CGAGGAAAAGCYATRTCAGGAGC & \\
\hline
\end{tabular}

Primer Link cox1

Primer Sequence 5'-3'

Fragment (bp) 


\begin{tabular}{lll}
\hline COINassaF & TCTACAAATCATAAAGACATTGG & cox1 (700) \\
COINassaR & ACYTCAGGATGACCAAARAATCA & \\
\hline
\end{tabular}

Tritia denticulata Sequenced by NIMGenetics, in a whole library

\begin{tabular}{lll}
$\begin{array}{l}\text { Long PCR } \\
\text { Primer }\end{array}$ & Sequence 5'-3' & Fragment (bp) \\
\hline $\begin{array}{l}\text { cox1laF } \\
\text { 12SlaR }\end{array}$ & AAYATRCGATGACGAGGRATRCARTTTGA & cox1-rrnS (4K) \\
\hline 12SlaF & CAGAGGCTGCACCTTGATCTGACGTYTT & \\
cobla2R & GGRTTAGCWGGRATAAARTTYTCWGGRTC & \\
\hline coblaF & GAYCCWGARAAYTTTATYCCTGCTAAYCC & cob-trnF (4.0K) \\
trnF-R & CACCCTAGCATCTTCAGTGCTATGCTCT & \\
\hline $\begin{array}{l}\text { cox3la2F } \\
\text { cox1laR }\end{array}$ & ATGGCRCGNAATCCTTTTCATTTAGTWGARTT & cox3-cox1 (2.5K) \\
\hline cox1 Genbank Acc. No: KY451292 & \\
\hline Primer Link cytb & & \\
Primer & Sequence 5'-3' & Fragment (bp) \\
\hline $\begin{array}{l}\text { cytbF } \\
\text { cytbR }\end{array}$ & GGWTAYGTWYTWCCWTGRGGWCARAT & cytb (0.5K) \\
\hline
\end{tabular}

Tritia ephamilla Sequenced by NIMGenetics, in a whole library

\begin{tabular}{lll}
$\begin{array}{l}\text { Long PCR } \\
\text { Primer }\end{array}$ & Sequence 5'-3' & Fragment (bp) \\
\hline $\begin{array}{l}\text { cox1laF } \\
\text { 12SlaR }\end{array}$ & AAYATRCGATGACGAGGRATRCARTTTGA & cox1-rrnS (4K) \\
\hline 12SlaF & CAGTGGTGGTATACCGTCGTCGTCAGGT & rrnS-cob (4.4K) \\
coblaR & GCYCCTCARAARGATATYTGACCTCARGG & \\
\hline coblaF & GAYCCWGARAAYTTTATYCCTGCTAAYCC & cob-trnF (4.0K) \\
trnF-R & CACCCTAGCATCTTCAGTGCTATGCTCT & \\
\hline cox3la2F & ATGGCRCGNAATCCTTTTCATTTAGTWGARTT & cox3-cox1 (2.5K) \\
cox1laR & CGAGGAAAAGCYATRTCAGGAGC & \\
\hline cox1 Genbank Acc. No: KY451298 & \\
\hline Primer Link cytb & & \\
Primer & Sequence 5'-3' & Fragment (bp) \\
\hline cytbF & GGWTAYGTWYTWCCWTGRGGWCARAT $(0.5 \mathrm{~K})$ \\
cytbR & GCRTAWGCRAAWARRAARTAYCAYTCWGG & \\
\hline
\end{tabular}

Tritia pallaryana Sequenced by NIMGenetics, in a whole library

\begin{tabular}{lll}
$\begin{array}{l}\text { Long PCR } \\
\text { Primer }\end{array}$ & Sequence 5'-3' & \\
\hline cox1laF & AAYATRCGATGACGAGGRATRCARTTTGA & cox1-rrnS (4K) \\
12 SlaR & ATAGGCTGCACCTTGATCTGACGTYTT & \\
\hline 12 SlaF & CAGTTTGTATACCGTCGTCGTCAGGT & rrnS-cob (4.5K)
\end{tabular}




\begin{tabular}{lll} 
cobla2R & GGRTTAGCWGGRATAAARTTYTCWGGRTC & \\
\hline cobla2F & CCYTGAGGTCARATATCYTTYTGAGGRGC & cob-trnF (4.3K) \\
trnF-R & CACCCTAGCATCTTCAGTGCTATGCTCT & \\
\hline cox3la2F & ATGGCRCGNAATCCTTTTCATTTAGTWGARTT & cox3-cox1 (2.5K) \\
cox1laR & CGAGGAAAAGCYATRTCAGGAGC & \\
\hline Primer Link cox1 & \\
Primer & Sequence 5'-3' & Fragment (bp) \\
\hline COI-tritiaF & ACWGCYCAYGCTTTYGTAATAAT & cox1 (400) \\
COI-tritiaR & TGYATNCCTCGTCATCGYATRTT & \\
\hline
\end{tabular}

Tritia tenuicosta Sequenced by NIMGenetics, in a whole library

Long PCR

\begin{tabular}{lll} 
Primer & Sequence 5'-3' & Fragment (bp) \\
\hline cox1laF & AAYATRCGATGACGAGGRATRCARTTTGA & cox1-rrnS (4K) \\
12SlaR & ATAGGCTGCACCTTGATCTGACGTYTT & \\
\hline 12SlaF & CAGTTTGTATACCGTCGTCGTCAGGT & rrnS-cob (4.4K) \\
coblaR & GCYCCTCARAARGATATYTGACCTCARGG & \\
\hline coblaF & GAYCCWGARAAYTTTATYCCTGCTAAYCC & cob-trnF (4.0K) \\
trnF-R & CACCCTAGCATCTTCAGTGCTATGCTCT & \\
\hline cox3la2F & ATGGCRCGNAATCCTTTTCATTTAGTWGARTT & cox3-cox1 (2.5K) \\
cox1laR & CGAGGAAAAGCYATRTCAGGAGC & \\
\hline cox1 Genbank Acc. No: KY489424 & \\
\hline Primer Link cytb & \\
Primer & Sequence 5'-3' & Fragment (bp) \\
\hline cytbF & GGWTAYGTWYTWCCWTGRGGWCARAT & cytb (0.5K) \\
cytbR & GCRTAWGCRAAWARRAARTAYCAYTCWGG & \\
\hline
\end{tabular}

\begin{tabular}{|c|c|c|}
\hline Tritia elongata & Sequenced by NIMGenetics, in a whole library & \\
\hline \multicolumn{3}{|l|}{ Long PCR } \\
\hline Primer & Sequence 5'-3' & Fragment (bp) \\
\hline cox1laF & AAYATRCGATGACGAGGRATRCARTTTGA & cox1-rrnS (4K) \\
\hline 12SlaR & ATAGGCTGCACCTTGATCTGACGTYTT & \\
\hline $12 \mathrm{SlaF}$ & CAGTTTGTATACCGTCGTCGTCAGGT & $r r n S-c o b(4.5 \mathrm{~K})$ \\
\hline cobla2R & GGRTTAGCWGGRATAAARTTYTCWGGRTC & \\
\hline cobla2F & CCYTGAGGTCARATATCYTTYTGAGGRGC & cob-trnF (4.3K) \\
\hline $\operatorname{trnF}-\mathrm{R}$ & CACCCTAGCATCTTCAGTGCTATGCTCT & \\
\hline cox3la2F & ATGGCRCGNAATCCTTTTCATTTAGTWGARTT & $\operatorname{cox} 3-\operatorname{cox} 1(2.5 \mathrm{~K})$ \\
\hline cox1laR & CGAGGAAAAGCYATRTCAGGAGC & \\
\hline cox1 Genb & ссс. No: KY489440 & \\
\hline
\end{tabular}

\begin{tabular}{lll} 
Tritia nitida & Sequenced by NIMGenetics, in a whole library & \\
\hline Long PCR & & \\
Primer & Sequence 5'-3' & Fragment (bp) \\
\hline cox1laF & AAYATRCGATGACGAGGRATRCARTTTGA & cox1-rrnS (4K)
\end{tabular}




\begin{tabular}{|c|c|c|}
\hline 12SlaR & ATAGGCTGCACCTTGATCTGACGTYTT & \\
\hline 12SlaF & CAGTTTGTATACCGTCGTCGTCAGGT & $r r n S-c o b(4.5 \mathrm{~K})$ \\
\hline cobla2R & GGRTTAGCWGGRATAAARTTYTCWGGRTC & \\
\hline cobla2F & CCYTGAGGTCARATATCYTTYTGAGGRGC & cob-trnF (4.3K) \\
\hline $\operatorname{trnF-R}$ & CACCCTAGCATCTTCAGTGCTATGCTCT & \\
\hline cox3la2F & ATGGCRCGNAATCCTTTTCATTTAGTWGARTT & $\operatorname{cox} 3-\operatorname{cox} 1(2.5 \mathrm{~K})$ \\
\hline cox1laR & CGAGGAAAAGCYATRTCAGGAGC & \\
\hline \multicolumn{3}{|c|}{ Primer Link cox1 } \\
\hline Primer & Sequence 5'-3' & Fragment (bp) \\
\hline LCO1490 F & GGTCAACAAATCATAAAGATATTGG & $\operatorname{cox} 1(709)$ \\
\hline HCO2198 R & TTAACTTCAGGGTGACCAAAAAATCA & \\
\hline itia varicosa & Sequenced by NIMGenetics, in a whole library & \\
\hline \multicolumn{3}{|l|}{ Long PCR } \\
\hline Primer & Sequence 5'-3' & Fragment (bp) \\
\hline cox1laF & AAYATRCGATGACGAGGRATRCARTTTGA & $\operatorname{cox} 1-r r n S(4 \mathrm{~K})$ \\
\hline 12SlaR & ATAGGCTGCACCTTGATCTGACGTYTT & \\
\hline 12SlaF & CAGTTTGTATACCGTCGTCGTCAGGT & $r r n S-c o b(4.5 \mathrm{~K})$ \\
\hline cobla2R & GGRTTAGCWGGRATAAARTTYTCWGGRTC & \\
\hline 16 slaF & GTGCAAAGGTAGCATAATCATTTGCCT & $r r n L-t r n F(6.1 \mathrm{~K})$ \\
\hline $\operatorname{trnF-R}$ & CACCCTAGCATCTTCAGTGCTATGCTCT & \\
\hline cox3la2F & ATGGCRCGNAATCCTTTTCATTTAGTWGARTT & $\operatorname{cox} 3-\operatorname{cox} 1(2.5 \mathrm{~K})$ \\
\hline cox1laR & CGAGGAAAAGCYATRTCAGGAGC & \\
\hline
\end{tabular}

\begin{tabular}{lll}
\hline \multicolumn{2}{l}{ Primer Link cox1 } & \\
Primer & Sequence 5'-3' & Fragment (bp) \\
\hline COINassaF & TCTACAAATCATAAAGACATTGG & $\operatorname{cox1}(700)$ \\
COINassaR & ACYTCAGGATGACCAAARAATCA & \\
\hline
\end{tabular}

Tritia elata Sequenced by NIMGenetics, in a whole library

\begin{tabular}{lll}
$\begin{array}{l}\text { Long PCR } \\
\text { Primer }\end{array}$ & Sequence 5'-3' & \\
\hline $\begin{array}{l}\text { cox1laF } \\
\text { 12SlaR }\end{array}$ & AAYATRCGATGACGAGGRATRCARTTTGA & cox1-rrnS (4K) \\
\hline 12SlaF & ATAGGCTGCACCTTGATCTGACGTYTT & \\
cobla2R & GGRTTTGTATACCGTCGTCGTCAGGT & rrnS-cob (4.5K) \\
\hline 16slaF & GTGCAAAGGTAGCATAATCATTTGCCT & rrnL-trnF (6.1K) \\
trnF-R & CACCCTAGCATCTTCAGTGCTATGCTCT & \\
\hline cox3la2F & ATGGCRCGNAATCCTTTTCATTTAGTWGARTT & cox3-cox1 (2.5K) \\
cox1laR & CGAGGAAAAGCYATRTCAGGAGC & \\
\hline Primer Link cox1 & \\
Primer & Sequence 5'-3' & Fragment (bp) \\
\hline COINassaF & TCTACAAATCATAAAGACATTGG & cox1 (700) \\
COINassaR & ACYTCAGGATGACCAAARAATCA & \\
\hline
\end{tabular}




\begin{tabular}{|c|c|c|}
\hline \multirow{2}{*}{$\begin{array}{r}\text { Tritia ovoidea } \\
\text { Long PCR }\end{array}$} & \multicolumn{2}{|l|}{ Sequenced by Sanger } \\
\hline & & \\
\hline Primer & Sequence 5'-3' & Fragment (bp) \\
\hline cox1laF & AAYATRCGATGACGAGGRATRCARTTTGA & cox1-rrnS (5.7K) \\
\hline 16SlaR & ATGCTGTTATCCCTACGGTAACTAATT & \\
\hline 16SZouF & GCGGTACTCTGACCGTGCAA & $r r n L-\operatorname{cob}(2.5 \mathrm{~K})$ \\
\hline coblaR & GCYCCTCARAARGATATYTGACCTCARGG & \\
\hline cox3la2F & ATGGCRCGNAATCCTTTTCATTTAGTWGARTT & $\operatorname{cox} 3-\operatorname{cox} 1(2.5 \mathrm{~K})$ \\
\hline cox1laR & CGAGGAAAAGCYATRTCAGGAGC & \\
\hline $15 \mathrm{~F}$ & TCAGCYTGTGGATTTGRARAT & $\operatorname{trnH}-\operatorname{trnF}(1.6 \mathrm{~K})$ \\
\hline $\operatorname{trnF-R}$ & CACCCTAGCATCTTCAGTGCTATGCTCT & \\
\hline \multicolumn{3}{|c|}{ Walking Primers } \\
\hline Primer & Sequence 5'-3' & Fragment (bp) \\
\hline $1 \mathrm{~F}$ & TGATTTCTTARGAGAGGTTCA & TrnQ-rrnS (1K) \\
\hline $1 \mathrm{R}$ & TGCTATGTTACGACTTATCTC & \\
\hline $2 \mathrm{~F}$ & AAGCTRTTGGGTTCATACCCC & $\operatorname{TrnM}-\operatorname{TrnE}(0.5 \mathrm{~K})$ \\
\hline $2 \mathrm{R}$ & TAGATTTTCATTCTAAARGRATA & \\
\hline $3 F$ & ATGCTTGTAGACATTTTTTCTTC & atp6-trnC (0.9K) \\
\hline $3 \mathrm{R}$ & TCGATTTTGCARRTCGATGTT & \\
\hline $4 \mathrm{~F}$ & TTTTAYGGTCARTGTTCYGAAAT & cox2-atp6 (0.8K) \\
\hline $4 \mathrm{R}$ & ACAATATGYCCRGCYCTTATRTT & \\
\hline $5 \mathrm{~F}$ & ATGAGCCTATGAGGACAAYTAGGATT & $\operatorname{cox} 2-\operatorname{trn} D(0.7 \mathrm{~K})$ \\
\hline $5 \mathrm{R}$ & GYRACRTAAGRCTGACAAYCT & \\
\hline $6 \mathrm{~F}$ & GAYATTATRCTYCAYGAYACHTAYTA & $\operatorname{cox} 1-\operatorname{cox} 2(0.7 \mathrm{~K})$ \\
\hline $6 \mathrm{R}$ & TCATAGCTTCARTATCATTGRTG & \\
\hline $7 \mathrm{~F}$ & AAYATRCGATGACGAGGRATRCA & $\operatorname{cox} 1(0.9 \mathrm{~K})$ \\
\hline $7 \mathrm{R}$ & GCYTCYCABACAATTACYATRAA & \\
\hline $9 \mathrm{~F}$ & AGGGCTGCTAACTTTGTTTTG & $\operatorname{trnS}-\operatorname{cox} 1(1.1 \mathrm{~K})$ \\
\hline 9R & ACRTTRTAAAGTTGRTCRTCACC & \\
\hline $10 \mathrm{~F}$ & CTAGCTGTTAATTAGRAGAAT & $\operatorname{trnN}-n d 2(0.75 \mathrm{~K})$ \\
\hline 10R & ATRAARTAYTTWACRGCYGAYTG & \\
\hline $11 \mathrm{~F}$ & TTYTTYTGAGCTTAYTTTCAYAG & cox3-trnI $(0.87 \mathrm{~K})$ \\
\hline $11 \mathrm{R}$ & ACATCAATGATTYCCGTTCAT & \\
\hline $15 \mathrm{~F}$ & TCAGCYTGTGGATTTGRARAT & $n d 5(0.9 \mathrm{~K})$ \\
\hline $15 \mathrm{R}$ & TTRTGRATAAATATHCCDGCRCA & \\
\hline $16 \mathrm{~F}$ & ATTGGNGCHAAYTAYGAAAAYGA & $n d 5-\operatorname{trnF}(0.9 \mathrm{~K})$ \\
\hline $\operatorname{trnF-R}$ & CACCCTAGCATCTTCAGTGCTATGCTCT & \\
\hline \multicolumn{3}{|c|}{ Standard PCR } \\
\hline Primer & Sequence 5'-3' & Fragment (bp) \\
\hline $12 \mathrm{~F}$ & ATGGCRCGTAATCCTTTTCATTT & $\operatorname{cox} 3-\operatorname{trn} A(0.8 \mathrm{~K})$ \\
\hline $12 \mathrm{R}$ & CTRAATGCAAATCARRTCTTT & \\
\hline $13 \mathrm{~F}$ & TTTGAAGCTTCTTTAATTCCWAC & $n d 4-\operatorname{trnH}(0.8 \mathrm{~K})$ \\
\hline $13 \mathrm{R}$ & ATYTYCAAATCCACARGCTGA & \\
\hline coblaF & GAYCCWGARAAYTTTATYCCTGCTAAYCC & cob-nd4 (0.9K) \\
\hline
\end{tabular}




\begin{tabular}{lll} 
14R & TTKACYCTATTTTGMCTYGCTAA & \\
\hline $18 \mathrm{~F}$ & DCATTCTGCCTGTTTAKCAAA & rrnL-trnL2 (0.8K) \\
$18 \mathrm{R}$ & GGGCTTAAACCTAATGCACTT & \\
\hline $19 \mathrm{~F}$ & AATGCAATTGACTTAGGMTCA & \\
$19 \mathrm{R}$ & ACCCAAGCTYTAGCTTCCAAT & nd1-nd6 (1K) \\
\hline $20 \mathrm{~F}$ & TTGGCAGTCGCTTTTTTTACTCT & \\
20R & CTAAARAYAATTARYGCTCTCAT & trnP-cob (0.6K) \\
\hline $21 \mathrm{~F}$ & ATTAGCATTGGAAGCTARAGC & \\
21R & AARATRGGRTGHACTTTTCGAAT & cob (1K) \\
\hline $22 \mathrm{~F}$ & ATGCGAAGTCCYATTCGAAAAGT & \\
22R & ACMGGACAAGCYCCAATTCAWGT & \\
\hline LCO1490 F & GGTCAACAAATCATAAAGATATTGG & rrnL-rrnS (1.2K) \\
HCO2198 R & TTAACTTCAGGGTGACCAAAAAATCA & \\
\hline 12SlaF & CAGTTTGTATACCGTCGTCGTCAGGT & cob-nd4 (1.2K) \\
16sZouR & TCACGTAGAATTTTAATGGTCG & \\
\hline coblaF & GAYCCWGARAAYTTTATYCCTGCTAAYCC & \\
nd4lnd4R & GGTAATGAAGCTGCTACAGTGTA & \\
\hline
\end{tabular}

Tritia tingitana Sequenced by Sanger

\begin{tabular}{lll}
$\begin{array}{l}\text { Long PCR } \\
\text { Primer }\end{array}$ & Sequence 5'-3' & Fragment (bp) \\
\hline $\begin{array}{l}\text { 16SZouF } \\
\text { coblaR }\end{array}$ & GCGGTACTCTGACCGTGCAA & rrnL-cob (2.5K) \\
\hline 12F & GCYCCTCARAARGATATYTGACCTCARGG & \\
cox1laR & ATGGCRCGTAATCCTTTTCATTT & cox3-cox1 (3K) \\
\hline 5F & ATGAGGAAAAGCYATRTCAGGAGC & \\
12slaR & ATAGGCTGCACCTTGATCTGACGTYTT & \\
\hline 15F & TCAGCYTGTGGATTTGRARAT & trnH-trnF (1.6K) \\
trnF-R & CACCCTAGCATCTTCAGTGCTATGCTCT & \\
\hline coblaF & GAYCCWGARAAYTTTATYCCTGCTAAYCC & cob-trnH (2.5K) \\
13R & ATYTYCAAATCCACARGCTGA & \\
\hline Walking Primers & Fragment (bp) \\
Primer & Sequence 5'-3' & TrnQ-rrnS (1K) \\
\hline 1F & TGATTTCTTARGAGAGGTTCA & \\
1R & TGCTATGTTACGACTTATCTC & TrnM-TrnE (0.5K) \\
\hline 2F & AAGCTRTTGGGTTCATACCCC & trnS-cox1 (1.1K) \\
2R & TAGATTTTCATTCTAAARGRATA & cox2-atp6 (0.8K) \\
\hline 3F & ATGCTTGTAGACATTTTTTCTTC & \\
3R & TCGATTTTGCARRTCGATGTT & cox2-trnD (0.7K) \\
\hline 4F & TTTTAYGGTCARTGTTCYGAAAT & \\
4R & ACAATATGYCCRGCYCTTATRTT & \\
\hline 5F & ATGAGCCTATGAGGACAAYTAGGATT & \\
5R & GYRACRTAAGRCTGACAAYCT & \\
\hline 9F & AGGGCTGCTAACTTTGTTTTG & \\
\hline
\end{tabular}




\begin{tabular}{|c|c|c|}
\hline $9 \mathrm{R}$ & ACRTTRTAAAGTTGRTCRTCACC & \\
\hline $10 \mathrm{~F}$ & CTAGCTGTTAATTAGRAGAAT & $\operatorname{trnN-nd2}(0.75 \mathrm{~K})$ \\
\hline 10R & ATRAARTAYTTWACRGCYGAYTG & \\
\hline $11 \mathrm{~F}$ & TTYTTYTGAGCTTAYTTTCAYAG & cox3-trnI $(0.87 \mathrm{~K})$ \\
\hline $11 \mathrm{R}$ & ACATCAATGATTYCCGTTCAT & \\
\hline $12 \mathrm{~F}$ & ATGGCRCGTAATCCTTTTCATTT & $\operatorname{cox} 3-\operatorname{trn} A(0.8 \mathrm{~K})$ \\
\hline $12 \mathrm{R}$ & CTRAATGCAAATCARRTCTTT & \\
\hline $13 \mathrm{~F}$ & TTTGAAGCTTCTTTAATTCCWAC & $n d 4-\operatorname{trnH}(0.8 \mathrm{~K})$ \\
\hline 13R & ATYTYCAAATCCACARGCTGA & \\
\hline coblaF & GAYCCWGARAAYTTTATYCCTGCTAAYCC & cob-nd4 (0.9K) \\
\hline $14 \mathrm{R}$ & TTKACYCTATTTTGMCTYGCTAA & \\
\hline $15 \mathrm{~F}$ & TCAGCYTGTGGATTTGRARAT & $n d 5(0.9 \mathrm{~K})$ \\
\hline $15 \mathrm{R}$ & TTRTGRATAAATATHCCDGCRCA & \\
\hline $16 \mathrm{~F}$ & ATTGGNGCHAAYTAYGAAAAYGA & $n d 5-\operatorname{trnF}(0.9 \mathrm{~K})$ \\
\hline $\operatorname{trnF-R}$ & CACCCTAGCATCTTCAGTGCTATGCTCT & \\
\hline $18 \mathrm{~F}$ & DCATTCTGCCTGTTTAKCAAA & $r r n L-t r n L 2(0.8 \mathrm{~K})$ \\
\hline $18 \mathrm{R}$ & GGGCTTAAACCTAATGCACTT & \\
\hline $19 \mathrm{~F}$ & AATGCAATTGACTTAGGMTCA & $\operatorname{trnL1-trnP}(1 \mathrm{~K})$ \\
\hline 19R & ACCCAAGCTYTAGCTTCCAAT & \\
\hline $20 \mathrm{~F}$ & TTGGCAGTCGCTTTTTTTACTCT & nd1-nd6 (1K) \\
\hline 20R & CTAAARAYAATTARYGCTCTCAT & \\
\hline $21 \mathrm{~F}$ & ATTAGCATTGGAAGCTARAGC & $\operatorname{trn} P-\operatorname{cob}(0.6 \mathrm{~K})$ \\
\hline 21R & AARATRGGRTGHACTTTTCGAAT & \\
\hline $22 \mathrm{~F}$ & ATGCGAAGTCCYATTCGAAAAGT & $\operatorname{cob}(1 \mathrm{~K})$ \\
\hline 22R & ACMGGACAAGCYCCAATTCAWGT & \\
\hline \multicolumn{3}{|c|}{ Standard PCR } \\
\hline Primer & Sequence 5'-3' & Fragment (bp) \\
\hline 12SlaF & CAGTTTGTATACCGTCGTCGTCAGGT & $r r n L-r r n S(1.2 \mathrm{~K})$ \\
\hline 16sZouR & TCACGTAGAATTTTAATGGTCG & \\
\hline cob-12870F & GGGTATGTCTTACCCTGAGGTCAGAT & $\operatorname{cob}(0.4 \mathrm{~K})$ \\
\hline cob-12870R & GCATACGCAAAGAGGAAGTATCATTCTGG & \\
\hline
\end{tabular}

\begin{tabular}{lll} 
Anentome sp. & Sequenced by NIMGenetics, in a whole library & \\
\hline $\begin{array}{l}\text { Long PCR } \\
\text { Primer }\end{array}$ & Sequence 5'-3' & Fragment (bp) \\
\hline $\begin{array}{l}\text { cox1laF } \\
\text { 12SlaR }\end{array}$ & AAYATRCGATGACGAGGRATRCARTTTGA & cox1-rrnS (4K) \\
\hline 12SlaF & CATAGGTGCACCTTGATCTGACGTYTT & \\
cobla2R & GGRTTAGCWGGRATAAARTTYTCWGGRTC & \\
\hline cobla2F & CCYTGAGGTCARATATCYTTYTGAGGRGC & \multirow{2}{*}{ cob-trnF (4.3K) } \\
trnF-R & CACCCTAGCATCTTCAGTGCTATGCTCT & \\
\hline cox3la2F & ATGGCRCGNAATCCTTTTCATTTAGTWGARTT & cox3-cox1 (2.5K) \\
cox1laR & CGAGGAAAAGCYATRTCAGGAGC & \\
\hline
\end{tabular}

\section{Primer Link cox1}




\begin{tabular}{lll} 
Primer & Sequence 5'-3' & Fragment (bp) \\
\hline LCO1490 F & GGTCAACAAATCATAAAGATATTGG & cox1 (709) \\
HCO2198 R & TTAACTTCAGGGTGACCAAAAAATCA & \\
\hline
\end{tabular}


Table S2. Best fit partitions and substitution models.

\begin{tabular}{|c|c|c|c|}
\hline & $\begin{array}{l}\text { Set Partition } \\
\text { (Conducted by } \\
\text { PartitionFinder 2) }\end{array}$ & $\begin{array}{l}\text { Best Model for BI } \\
\text { (Selected by } \\
\text { PartitionFinder 2) }\end{array}$ & $\begin{array}{l}\text { Best Model for } \\
\text { ML (Selected by } \\
\text { IQtree 1.6.10) }\end{array}$ \\
\hline Best Partition CDS genes & atp6-8 1th & $\mathrm{TRN}+\mathrm{G}$ & $\mathrm{TN}+\mathrm{F}+\mathrm{G} 4$ \\
\hline \multirow[t]{11}{*}{$(\mathrm{BIC}=254577.82)$} & atp6-8 2th & K81UF+I & $\mathrm{K} 3 \mathrm{Pu}+\mathrm{F}+\mathrm{I}$ \\
\hline & atp6-8 3th & $\mathrm{TVM}+\mathrm{I}+\mathrm{G}$ & $\mathrm{K} 3 \mathrm{Pu}+\mathrm{F}+\mathrm{I}+\mathrm{G} 4$ \\
\hline & $\operatorname{cox} 1-2-3$ 1th & $\mathrm{TRN}+\mathrm{I}+\mathrm{G}$ & $\mathrm{TN}+\mathrm{F}+\mathrm{I}+\mathrm{G} 4$ \\
\hline & $\operatorname{cox} 1-2-3$ 2th & $\mathrm{TVM}+\mathrm{I}+\mathrm{G}$ & $\mathrm{TVM}+\mathrm{F}+\mathrm{I}+\mathrm{G} 4$ \\
\hline & cox1-2-3 3th & $\mathrm{GTR}+\mathrm{I}+\mathrm{G}$ & $\mathrm{TVM}+\mathrm{F}+\mathrm{I}+\mathrm{G} 4$ \\
\hline & cob 1th & $\mathrm{TRN}+\mathrm{I}+\mathrm{G}$ & TIM2+F+I+G4 \\
\hline & cob 2th & $\mathrm{TVM}+\mathrm{I}+\mathrm{G}$ & $\mathrm{TVM}+\mathrm{F}+\mathrm{I}+\mathrm{G} 4$ \\
\hline & cob 3th & $\mathrm{K} 81 \mathrm{UF}+\mathrm{I}+\mathrm{G}$ & $\mathrm{K} 3 \mathrm{Pu}+\mathrm{F}+\mathrm{I}+\mathrm{G} 4$ \\
\hline & nad1-2-3-4-4L-5-6 1th & $\mathrm{GTR}+\mathrm{I}+\mathrm{G}$ & TIM3+F+I+G4 \\
\hline & nad1-2-3-4-4L-5-6 2th & $\mathrm{GTR}+\mathrm{I}+\mathrm{G}$ & $\mathrm{GTR}+\mathrm{F}+\mathrm{I}+\mathrm{G} 4$ \\
\hline & nad1-2-3-4-4L-5-6 3th & $\mathrm{GTR}+\mathrm{I}+\mathrm{G}$ & $\mathrm{TVM}+\mathrm{F}+\mathrm{I}+\mathrm{G} 4$ \\
\hline $\begin{array}{l}\text { Best Partition to rRNA genes } \\
(\mathrm{BIC}=26625.61)\end{array}$ & $r r n S-L$ & $\mathrm{GTR}+\mathrm{I}+\mathrm{G}$ & $\mathrm{GTR}+\mathrm{F}+\mathrm{I}+\mathrm{G} 4$ \\
\hline
\end{tabular}


Table S3. Mitochondrial genome features

Tritia corniculum 15,114 bp

\begin{tabular}{|c|c|c|c|c|c|c|}
\hline Gene & Strand & Location & $\begin{array}{l}\text { Size } \\
\text { (bp) }\end{array}$ & $\begin{array}{l}\text { Start } \\
\text { Codon }\end{array}$ & $\begin{array}{l}\text { Stop } \\
\text { codon }\end{array}$ & $\begin{array}{l}\text { Intergenic } \\
\text { nucleotides }\end{array}$ \\
\hline Cox3 & $\mathrm{H}$ & $1-747$ & incomplete & - & TAG & 15 \\
\hline tRNA-Lys & $\mathrm{H}$ & $763-827$ & 65 & & & 1 \\
\hline tRNA-Ala & $\mathrm{H}$ & 829-896 & 68 & & & 9 \\
\hline tRNA-Arg & $\mathrm{H}$ & $906-974$ & 69 & & & 5 \\
\hline tRNA-Asn & $\mathrm{H}$ & $980-1047$ & 68 & & & 15 \\
\hline tRNA-Ile & $\mathrm{H}$ & $1063-1130$ & 68 & & & 3 \\
\hline Nad3 & $\mathrm{H}$ & $1134-1487$ & 354 & ATG & TAA & 0 \\
\hline tRNA-Ser & $\mathrm{H}$ & $1488-1555$ & 68 & & & 0 \\
\hline Nad2 & $\mathrm{H}$ & $1556-2610$ & 1055 & ATG & $\mathrm{TA}$ & 0 \\
\hline Cox1 & $\mathrm{H}$ & $2611-4146$ & 1536 & ATG & TAA & 29 \\
\hline Cox2 & $\mathrm{H}$ & $4176-4862$ & 687 & ATG & TAA & -2 \\
\hline tRNA-ASp & $\mathrm{H}$ & $4861-4928$ & 68 & & & 1 \\
\hline Atp8 & $\mathrm{H}$ & $4930-5088$ & 159 & ATG & TAA & 7 \\
\hline Atp6 & $\mathrm{H}$ & 5096-5791 & 696 & ATG & TAA & 38 \\
\hline tRNA-Met & $\mathrm{L}$ & $5830-5896$ & 67 & & & 3 \\
\hline tRNA-Tyr & $\mathrm{L}$ & $5900-5967$ & 68 & & & 1 \\
\hline tRNA-Cys & $\mathrm{L}$ & $5969-6033$ & 65 & & & 0 \\
\hline tRNA-Trp & $\mathrm{L}$ & 6034-6099 & 66 & & & 1 \\
\hline tRNA-Gln & $\mathrm{L}$ & 6101-6162 & 62 & & & 1 \\
\hline tRNA-Gly & $\mathrm{L}$ & 6164-6231 & 68 & & & 11 \\
\hline tRNA-Glu & $\mathrm{L}$ & $6243-6307$ & 65 & & & 0 \\
\hline $12 \mathrm{~s}$ & $\mathrm{H}$ & 6308-7265 & 958 & & & 0 \\
\hline tRNA-Val & $\mathrm{H}$ & 7266-7333 & 68 & & & 0 \\
\hline $16 \mathrm{~s}$ & $\mathrm{H}$ & 7334-8685 & 1352 & & & 0 \\
\hline tRNA-Leu & $\mathrm{H}$ & $8686-8757$ & 72 & & & 2 \\
\hline tRNA-Leu & $\mathrm{H}$ & $8760-8828$ & 69 & & & 0 \\
\hline Nad1 & $\mathrm{H}$ & $8829-9770$ & 942 & ATG & TAA & 6 \\
\hline tRNA-Pro & $\mathrm{H}$ & $9777-9844$ & 68 & & & 1 \\
\hline Nad6 & $\mathrm{H}$ & $9846-10346$ & 501 & ATG & TAG & 5 \\
\hline Cytb & $\mathrm{H}$ & 10352-11491 & 1140 & ATG & TAA & 9 \\
\hline tRNA-Ser & $\mathrm{H}$ & $11502-11565$ & 64 & & & 0 \\
\hline tRNA-Thr & $\mathrm{L}$ & $11566-11630$ & 65 & & & 20 \\
\hline Nad4L & $\mathrm{H}$ & 11651-11947 & 297 & ATG & TAG & 11 \\
\hline $\mathrm{Nad} 4$ & $\mathrm{H}$ & 11959-13314 & 1356 & ATA & TAG & -1 \\
\hline tRNA-His & $\mathrm{H}$ & 13314-13378 & 65 & & & 0 \\
\hline Nad5 & $\mathrm{H}$ & 13379-15100 & 1722 & ATG & TAG & 14 \\
\hline tRNA-Phe & $\mathrm{H}$ & missing & - & & & - \\
\hline
\end{tabular}


Tritia cuvierii 15,185 bp

\begin{tabular}{|c|c|c|c|c|c|c|}
\hline Gene & Strand & Location & $\begin{array}{l}\text { Size } \\
\text { (bp) }\end{array}$ & $\begin{array}{l}\text { Start } \\
\text { Codon }\end{array}$ & $\begin{array}{l}\text { Stop } \\
\text { codon }\end{array}$ & $\begin{array}{l}\text { Intergenic } \\
\text { nucleotides }\end{array}$ \\
\hline Cox3 & $\mathrm{H}$ & $1-776$ & incomplete & - & TAA & 12 \\
\hline tRNA-Lys & $\mathrm{H}$ & 789-853 & 65 & & & 2 \\
\hline tRNA-Ala & $\mathrm{H}$ & 856-922 & 67 & & & 10 \\
\hline tRNA-Arg & $\mathrm{H}$ & 933-1001 & 69 & & & 8 \\
\hline tRNA-Asn & $\mathrm{H}$ & $1010-1077$ & 68 & & & 17 \\
\hline tRNA-Ile & $\mathrm{H}$ & $1095-1162$ & 68 & & & 3 \\
\hline $\mathrm{Nad} 3$ & $\mathrm{H}$ & $1166-1519$ & 354 & ATG & TAG & 0 \\
\hline tRNA-Ser & $\mathrm{H}$ & $1520-1587$ & 68 & & & 0 \\
\hline $\mathrm{Nad} 2$ & $\mathrm{H}$ & $1588-2642$ & 1055 & ATG & $\mathrm{TA}$ & 0 \\
\hline Cox1 & $\mathrm{H}$ & $2643-4178$ & 1536 & ATG & TAA & 26 \\
\hline Cox2 & $\mathrm{H}$ & $4205-4891$ & 687 & ATG & TAA & -2 \\
\hline tRNA-ASp & $\mathrm{H}$ & $4890-4957$ & 68 & & & 1 \\
\hline Atp8 & $\mathrm{H}$ & $4959-5117$ & 159 & ATG & TAA & 6 \\
\hline Atp6 & $\mathrm{H}$ & $5124-5819$ & 696 & ATG & TAA & 42 \\
\hline tRNA-Met & $\mathrm{L}$ & $5862-5928$ & 67 & & & 4 \\
\hline tRNA-Tyr & $\mathrm{L}$ & 5933-5999 & 67 & & & 1 \\
\hline tRNA-Cys & $\mathrm{L}$ & 6001-6066 & 66 & & & 0 \\
\hline tRNA-Trp & $\mathrm{L}$ & $6067-6132$ & 66 & & & 0 \\
\hline tRNA-Gln & $\mathrm{L}$ & 6133-6196 & 64 & & & 1 \\
\hline tRNA-Gly & $\mathrm{L}$ & $6198-6264$ & 67 & & & 14 \\
\hline tRNA-Glu & $\mathrm{L}$ & $6279-6343$ & 65 & & & 0 \\
\hline $12 \mathrm{~s}$ & $\mathrm{H}$ & $6344-7302$ & 959 & & & 0 \\
\hline tRNA-Val & $\mathrm{H}$ & $7303-7370$ & 68 & & & 0 \\
\hline $16 \mathrm{~s}$ & $\mathrm{H}$ & $7371-8723$ & 1353 & & & 0 \\
\hline tRNA-Leu & $\mathrm{H}$ & 8724-8792 & 69 & & & 2 \\
\hline tRNA-Leu & $\mathrm{H}$ & 8795-8863 & 69 & & & 0 \\
\hline Nad1 & $\mathrm{H}$ & 8864-9805 & 942 & ATG & TAA & 5 \\
\hline tRNA-Pro & $\mathrm{H}$ & $9811-9878$ & 68 & & & 1 \\
\hline Nad6 & $\mathrm{H}$ & $9880-10380$ & 501 & ATG & TAA & 5 \\
\hline Cytb & $\mathrm{H}$ & 10386-11525 & 1140 & ATG & TAA & 9 \\
\hline tRNA-Ser & $\mathrm{H}$ & 11535-11599 & 65 & & & 0 \\
\hline tRNA-Thr & $\mathrm{L}$ & $11600-11667$ & 68 & & & 25 \\
\hline Nad4L & $\mathrm{H}$ & 11693-11989 & 297 & ATG & TAG & 11 \\
\hline Nad4 & $\mathrm{H}$ & 12001-13356 & 1356 & ATA & TAG & -1 \\
\hline tRNA-His & $\mathrm{H}$ & 13356-13421 & 66 & & & 1 \\
\hline Nad5 & $\mathrm{H}$ & 13423-15144 & 1722 & ATG & TAG & 41 \\
\hline tRNA-Phe & $\mathrm{H}$ & missing & - & & & - \\
\hline
\end{tabular}


Tritia denticulata 15,167 bp

\begin{tabular}{|c|c|c|c|c|c|c|}
\hline Gene & Strand & Location & $\begin{array}{l}\text { Size } \\
\text { (bp) }\end{array}$ & $\begin{array}{l}\text { Start } \\
\text { Codon }\end{array}$ & $\begin{array}{l}\text { Stop } \\
\text { codon }\end{array}$ & $\begin{array}{l}\text { Intergenic } \\
\text { nucleotides }\end{array}$ \\
\hline Cox3 & $\mathrm{H}$ & $1-771$ & incomplete & - & TAA & 15 \\
\hline tRNA-Lys & $\mathrm{H}$ & $787-852$ & 66 & & & 3 \\
\hline tRNA-Ala & $\mathrm{H}$ & 856-923 & 68 & & & 8 \\
\hline tRNA-Arg & $\mathrm{H}$ & $932-1002$ & 71 & & & 7 \\
\hline tRNA-Asn & $\mathrm{H}$ & $1010-1076$ & 67 & & & 17 \\
\hline tRNA-Ile & $\mathrm{H}$ & $1094-1161$ & 68 & & & 3 \\
\hline Nad3 & $\mathrm{H}$ & $1165-1518$ & 354 & ATG & TAA & 0 \\
\hline tRNA-Ser & $\mathrm{H}$ & $1519-1586$ & 68 & & & 0 \\
\hline $\mathrm{Nad} 2$ & $\mathrm{H}$ & $1587-2641$ & 1055 & ATG & $\mathrm{TA}$ & 0 \\
\hline Cox1 & $\mathrm{H}$ & $2642-4177$ & 1536 & ATG & TAA & 22 \\
\hline Cox2 & $\mathrm{H}$ & $4200-4886$ & 687 & ATG & TAA & -2 \\
\hline tRNA-Asp & $\mathrm{H}$ & $4885-4952$ & 68 & & & 1 \\
\hline Atp8 & $\mathrm{H}$ & $4954-5112$ & 159 & ATG & TAA & 7 \\
\hline Atp6 & $\mathrm{H}$ & 5120-5815 & 696 & ATG & TAA & 42 \\
\hline tRNA-Met & $\mathrm{L}$ & 5858-5924 & 67 & & & 6 \\
\hline tRNA-Tyr & $\mathrm{L}$ & 5931-5998 & 68 & & & 1 \\
\hline tRNA-Cys & $\mathrm{L}$ & $6000-6063$ & 64 & & & 0 \\
\hline tRNA-Trp & $\mathrm{L}$ & 6064-6129 & 66 & & & -3 \\
\hline tRNA-Gln & $\mathrm{L}$ & 6127-6193 & 67 & & & -1 \\
\hline tRNA-Gly & $\mathrm{L}$ & 6193-6261 & 69 & & & 12 \\
\hline tRNA-Glu & $\mathrm{L}$ & 6274-6338 & 65 & & & 0 \\
\hline $12 \mathrm{~s}$ & $\mathrm{H}$ & 6339-7296 & 958 & & & 0 \\
\hline tRNA-Val & $\mathrm{H}$ & $7297-7364$ & 68 & & & 0 \\
\hline $16 \mathrm{~s}$ & $\mathrm{H}$ & $7365-8716$ & 1352 & & & 0 \\
\hline tRNA-Leu & $\mathrm{H}$ & 8717-8785 & 69 & & & 2 \\
\hline tRNA-Leu & $\mathrm{H}$ & 8788-8856 & 69 & & & 0 \\
\hline Nad1 & $\mathrm{H}$ & 8857-9798 & 942 & ATG & TAG & 6 \\
\hline tRNA-Pro & $\mathrm{H}$ & $9805-9872$ & 68 & & & 1 \\
\hline Nad6 & $\mathrm{H}$ & 9874-10374 & 501 & ATG & TAA & 6 \\
\hline Cytb & $\mathrm{H}$ & $10381-11520$ & 1140 & ATG & TAA & 10 \\
\hline tRNA-Ser & $\mathrm{H}$ & 11531-11595 & 65 & & & -1 \\
\hline tRNA-Thr & $\mathrm{L}$ & $11595-11664$ & 70 & & & 18 \\
\hline Nad4L & $\mathrm{H}$ & 11683-11979 & 297 & ATG & TAG & 11 \\
\hline Nad4 & $\mathrm{H}$ & 11991-13346 & 1356 & ATA & TAG & -1 \\
\hline tRNA-His & $\mathrm{H}$ & 13346-13412 & 67 & & & 1 \\
\hline Nad5 & $\mathrm{H}$ & 13414-15135 & 1722 & ATG & TAG & 32 \\
\hline tRNA-Phe & $\mathrm{H}$ & missing & - & & & - \\
\hline
\end{tabular}


Tritia elongata 15,145 bp

\begin{tabular}{|c|c|c|c|c|c|c|}
\hline Gene & Strand & Location & $\begin{array}{l}\text { Size } \\
\text { (bp) }\end{array}$ & $\begin{array}{l}\text { Start } \\
\text { Codon }\end{array}$ & $\begin{array}{l}\text { Stop } \\
\text { codon }\end{array}$ & $\begin{array}{l}\text { Intergenic } \\
\text { nucleotides }\end{array}$ \\
\hline Cox3 & $\mathrm{H}$ & $1-752$ & incomplete & - & TAA & 12 \\
\hline tRNA-Lys & $\mathrm{H}$ & 765-831 & 67 & & & -1 \\
\hline tRNA-Ala & $\mathrm{H}$ & $831-900$ & 70 & & & 7 \\
\hline tRNA-Arg & $\mathrm{H}$ & $908-978$ & 71 & & & 2 \\
\hline tRNA-Asn & $\mathrm{H}$ & $981-1047$ & 67 & & & 14 \\
\hline tRNA-Ile & $\mathrm{H}$ & $1062-1129$ & 68 & & & 3 \\
\hline $\mathrm{Nad} 3$ & $\mathrm{H}$ & $1133-1486$ & 354 & ATG & TAG & 0 \\
\hline tRNA-Ser & $\mathrm{H}$ & $1487-1554$ & 68 & & & 0 \\
\hline $\mathrm{Nad} 2$ & $\mathrm{H}$ & $1555-2609$ & 1055 & ATG & $\mathrm{TA}$ & 0 \\
\hline Cox1 & $\mathrm{H}$ & $2610-4145$ & 1536 & ATG & TAA & 29 \\
\hline Cox2 & $\mathrm{H}$ & $4175-4861$ & 687 & ATG & TAA & -2 \\
\hline tRNA-ASp & $\mathrm{H}$ & $4860-4927$ & 68 & & & 1 \\
\hline Atp8 & $\mathrm{H}$ & $4929-5087$ & 159 & ATG & TAA & 7 \\
\hline Atp6 & $\mathrm{H}$ & $5095-5790$ & 696 & ATG & TAA & 38 \\
\hline tRNA-Met & $\mathrm{L}$ & 5829-5895 & 67 & & & 1 \\
\hline tRNA-Tyr & $\mathrm{L}$ & 5897-5968 & 72 & & & -1 \\
\hline tRNA-Cys & $\mathrm{L}$ & 5968-6032 & 65 & & & 0 \\
\hline tRNA-Trp & $\mathrm{L}$ & 6033-6098 & 66 & & & -3 \\
\hline tRNA-Gln & $\mathrm{L}$ & 6096-6162 & 67 & & & 0 \\
\hline tRNA-Gly & $\mathrm{L}$ & $6163-6231$ & 69 & & & 12 \\
\hline tRNA-Glu & $\mathrm{L}$ & 6244-6308 & 65 & & & 0 \\
\hline $12 \mathrm{~s}$ & $\mathrm{H}$ & $6309-7267$ & 959 & & & 0 \\
\hline tRNA-Val & $\mathrm{H}$ & $7268-7335$ & 68 & & & 0 \\
\hline $16 \mathrm{~s}$ & $\mathrm{H}$ & 7336-8686 & 1351 & & & 0 \\
\hline tRNA-Leu & $\mathrm{H}$ & $8687-8756$ & 70 & & & 1 \\
\hline tRNA-Leu & $\mathrm{H}$ & 8758-8828 & 71 & & & -1 \\
\hline Nad1 & $\mathrm{H}$ & 8828-9769 & 942 & ATG & TAG & 6 \\
\hline tRNA-Pro & $\mathrm{H}$ & $9776-9843$ & 68 & & & 1 \\
\hline Nad6 & $\mathrm{H}$ & $9845-10345$ & 501 & ATG & TAA & 5 \\
\hline Cytb & $\mathrm{H}$ & $10351-11490$ & 1140 & ATG & TAA & 8 \\
\hline tRNA-Ser & $\mathrm{H}$ & 11499-11569 & 71 & & & -2 \\
\hline tRNA-Thr & $\mathrm{L}$ & 11568-11635 & 68 & & & 19 \\
\hline Nad4L & $\mathrm{H}$ & 11655-11951 & 297 & ATG & TAG & 11 \\
\hline Nad4 & $\mathrm{H}$ & 11963-13318 & 1356 & ATA & TAG & -1 \\
\hline tRNA-His & $\mathrm{H}$ & 13318-13382 & 65 & & & 0 \\
\hline Nad5 & $\mathrm{H}$ & 13383-15104 & 1722 & ATG & TAG & 41 \\
\hline tRNA-Phe & $\mathrm{H}$ & missing & - & & & - \\
\hline
\end{tabular}


Tritia ephamilla 15,186 bp

\begin{tabular}{|c|c|c|c|c|c|c|}
\hline Gene & Strand & Location & $\begin{array}{l}\text { Size } \\
\text { (bp) }\end{array}$ & $\begin{array}{l}\text { Start } \\
\text { Codon }\end{array}$ & $\begin{array}{l}\text { Stop } \\
\text { codon }\end{array}$ & $\begin{array}{l}\text { Intergenic } \\
\text { nucleotides }\end{array}$ \\
\hline Cox3 & $\mathrm{H}$ & $1-776$ & incomplete & - & TAA & 15 \\
\hline tRNA-Lys & $\mathrm{H}$ & 792-856 & 65 & & & 1 \\
\hline tRNA-Ala & $\mathrm{H}$ & 858-925 & 68 & & & 9 \\
\hline tRNA-Arg & $\mathrm{H}$ & $935-1003$ & 69 & & & 9 \\
\hline tRNA-Asn & $\mathrm{H}$ & $1013-1080$ & 68 & & & 18 \\
\hline tRNA-Ile & $\mathrm{H}$ & 1099-1166 & 68 & & & 3 \\
\hline $\mathrm{Nad} 3$ & $\mathrm{H}$ & $1170-1523$ & 354 & ATG & TAA & -1 \\
\hline tRNA-Ser & $\mathrm{H}$ & $1523-1592$ & 70 & & & -1 \\
\hline $\mathrm{Nad} 2$ & $\mathrm{H}$ & $1592-2646$ & 1055 & ATG & $\mathrm{TA}$ & 0 \\
\hline Cox1 & $\mathrm{H}$ & $2647-4182$ & 1536 & ATG & TAA & 27 \\
\hline Cox2 & $\mathrm{H}$ & $4210-4896$ & 687 & ATG & TAA & -2 \\
\hline tRNA-Asp & $\mathrm{H}$ & $4895-4962$ & 68 & & & 1 \\
\hline Atp8 & $\mathrm{H}$ & $4964-5122$ & 159 & ATG & TAA & 7 \\
\hline Atp6 & $\mathrm{H}$ & $5130-5825$ & 696 & ATG & TAA & 43 \\
\hline tRNA-Met & $\mathrm{L}$ & $5869-5935$ & 67 & & & 2 \\
\hline tRNA-Tyr & $\mathrm{L}$ & $5938-6003$ & 66 & & & 1 \\
\hline tRNA-Cys & $\mathrm{L}$ & $6005-6069$ & 65 & & & 0 \\
\hline tRNA-Trp & $\mathrm{L}$ & 6070-6135 & 66 & & & -3 \\
\hline tRNA-Gln & $\mathrm{L}$ & 6133-6199 & 67 & & & -1 \\
\hline tRNA-Gly & $\mathrm{L}$ & 6199-6267 & 69 & & & 13 \\
\hline tRNA-Glu & $\mathrm{L}$ & 6281-6345 & 65 & & & 0 \\
\hline $12 \mathrm{~s}$ & $\mathrm{H}$ & 6346-7301 & 956 & & & 0 \\
\hline tRNA-Val & $\mathrm{H}$ & $7302-7369$ & 68 & & & 0 \\
\hline $16 \mathrm{~s}$ & $\mathrm{H}$ & $7370-8719$ & 1350 & & & 0 \\
\hline tRNA-Leu & $\mathrm{H}$ & $8720-8788$ & 69 & & & 2 \\
\hline tRNA-Leu & $\mathrm{H}$ & 8791-8861 & 71 & & & -1 \\
\hline Nad1 & $\mathrm{H}$ & 8861-9802 & 942 & ATG & TAA & 6 \\
\hline tRNA-Pro & $\mathrm{H}$ & $9809-9876$ & 68 & & & 1 \\
\hline Nad6 & $\mathrm{H}$ & $9878-10378$ & 501 & ATG & TAA & 4 \\
\hline Cytb & $\mathrm{H}$ & 10383-11522 & 1140 & ATG & TAA & 16 \\
\hline tRNA-Ser & $\mathrm{H}$ & 11539-11603 & 65 & & & -1 \\
\hline tRNA-Thr & $\mathrm{L}$ & $11603-11673$ & 71 & & & 20 \\
\hline Nad4L & $\mathrm{H}$ & 11694-11990 & 297 & ATG & TAG & 11 \\
\hline Nad4 & $\mathrm{H}$ & 12002-13357 & 1356 & ATA & TAG & -1 \\
\hline tRNA-His & $\mathrm{H}$ & $13357-13422$ & 66 & & & 1 \\
\hline Nad5 & $\mathrm{H}$ & $13424-15145$ & 1722 & ATG & TAG & 41 \\
\hline tRNA-Phe & $\mathrm{H}$ & missing & - & & & - \\
\hline
\end{tabular}


Tritia grana 15,198 bp

\begin{tabular}{|c|c|c|c|c|c|c|}
\hline Gene & Strand & Location & $\begin{array}{l}\text { Size } \\
\text { (bp) }\end{array}$ & $\begin{array}{l}\text { Start } \\
\text { Codon }\end{array}$ & $\begin{array}{l}\text { Stop } \\
\text { codon }\end{array}$ & $\begin{array}{l}\text { Intergenic } \\
\text { nucleotides }\end{array}$ \\
\hline Cox3 & $\mathrm{H}$ & $1-770$ & incomplete & - & TAA & 15 \\
\hline tRNA-Lys & $\mathrm{H}$ & $786-850$ & 65 & & & 1 \\
\hline tRNA-Ala & $\mathrm{H}$ & 851-918 & 68 & & & 9 \\
\hline tRNA-Arg & $\mathrm{H}$ & 928-996 & 69 & & & 16 \\
\hline tRNA-Asn & $\mathrm{H}$ & $1013-1080$ & 68 & & & 12 \\
\hline tRNA-Ile & $\mathrm{H}$ & $1093-1160$ & 68 & & & 3 \\
\hline $\mathrm{Nad} 3$ & $\mathrm{H}$ & $1164-1517$ & 354 & ATG & TAG & 0 \\
\hline tRNA-Ser & $\mathrm{H}$ & $1518-1585$ & 68 & & & 0 \\
\hline $\mathrm{Nad} 2$ & $\mathrm{H}$ & $1586-2641$ & 1056 & ATG & TAA & 0 \\
\hline Cox1 & $\mathrm{H}$ & $2642-4177$ & 1536 & ATG & TAA & 28 \\
\hline Cox2 & $\mathrm{H}$ & 4206-4892 & 687 & ATG & TAA & -2 \\
\hline tRNA-Asp & $\mathrm{H}$ & $4891-4958$ & 68 & & & 1 \\
\hline Atp8 & $\mathrm{H}$ & $4960-5118$ & 159 & ATG & TAA & 7 \\
\hline Atp6 & $\mathrm{H}$ & $5126-5821$ & 696 & ATG & TAA & 41 \\
\hline tRNA-Met & $\mathrm{L}$ & $5863-5929$ & 67 & & & 2 \\
\hline tRNA-Tyr & $\mathrm{L}$ & $5932-5999$ & 68 & & & 1 \\
\hline tRNA-Cys & $\mathrm{L}$ & 6001-6066 & 66 & & & 0 \\
\hline tRNA-Trp & $\mathrm{L}$ & $6067-6132$ & 66 & & & 1 \\
\hline tRNA-Gln & $\mathrm{L}$ & 6134-6195 & 62 & & & 1 \\
\hline tRNA-Gly & $\mathrm{L}$ & $6197-6264$ & 68 & & & 12 \\
\hline tRNA-Glu & $\mathrm{L}$ & $6277-6341$ & 65 & & & 0 \\
\hline $12 \mathrm{~s}$ & $\mathrm{H}$ & $6342-7302$ & 961 & & & 0 \\
\hline tRNA-Val & $\mathrm{H}$ & $7303-7370$ & 68 & & & 0 \\
\hline $16 \mathrm{~s}$ & $\mathrm{H}$ & $7371-8720$ & 1350 & & & 0 \\
\hline tRNA-Leu & $\mathrm{H}$ & 8721-8789 & 69 & & & 2 \\
\hline tRNA-Leu & $\mathrm{H}$ & $8792-8860$ & 69 & & & 0 \\
\hline Nad1 & $\mathrm{H}$ & 8861-9802 & 942 & ATG & TAA & 6 \\
\hline tRNA-Pro & $\mathrm{H}$ & $9809-9876$ & 68 & & & 1 \\
\hline Nad6 & $\mathrm{H}$ & $9878-10378$ & 501 & ATG & TAA & 18 \\
\hline Cytb & $\mathrm{H}$ & $10397-11536$ & 1140 & ATG & TAA & 12 \\
\hline tRNA-Ser & $\mathrm{H}$ & 11549-11614 & 66 & & & 0 \\
\hline tRNA-Thr & $\mathrm{L}$ & 11615-11682 & 68 & & & 23 \\
\hline Nad4L & $\mathrm{H}$ & 11706-12002 & 297 & ATG & TAG & 11 \\
\hline Nad4 & $\mathrm{H}$ & 12014-13369 & 1356 & ATA & TAG & -1 \\
\hline tRNA-His & $\mathrm{H}$ & 13369-13434 & 66 & & & 1 \\
\hline Nad5 & $\mathrm{H}$ & 13436-15157 & 1722 & ATG & TAG & 41 \\
\hline tRNA-Phe & $\mathrm{H}$ & missing & - & & & - \\
\hline
\end{tabular}


Tritia incrassata-Norway 15,170 bp

\begin{tabular}{|c|c|c|c|c|c|c|}
\hline Gene & Strand & Location & $\begin{array}{l}\text { Size } \\
\text { (bp) }\end{array}$ & $\begin{array}{l}\text { Start } \\
\text { Codon }\end{array}$ & $\begin{array}{l}\text { Stop } \\
\text { codon }\end{array}$ & $\begin{array}{l}\text { Intergenic } \\
\text { nucleotides }\end{array}$ \\
\hline Cox3 & $\mathrm{H}$ & $1-772$ & incomplete & - & TAA & 14 \\
\hline tRNA-Lys & $\mathrm{H}$ & 787-851 & 65 & & & 1 \\
\hline tRNA-Ala & $\mathrm{H}$ & $853-920$ & 68 & & & 9 \\
\hline tRNA-Arg & $\mathrm{H}$ & 930-998 & 69 & & & 7 \\
\hline tRNA-Asn & $\mathrm{H}$ & $1006-1072$ & 67 & & & 15 \\
\hline tRNA-Ile & $\mathrm{H}$ & $1088-1154$ & 67 & & & 3 \\
\hline $\mathrm{Nad} 3$ & $\mathrm{H}$ & $1158-1511$ & 354 & ATG & TAA & 0 \\
\hline tRNA-Ser & $\mathrm{H}$ & $1512-1579$ & 68 & & & 0 \\
\hline $\mathrm{Nad} 2$ & $\mathrm{H}$ & $1580-2634$ & 1055 & ATG & $\mathrm{TA}$ & 0 \\
\hline Cox1 & $\mathrm{H}$ & $2635-4170$ & 1536 & ATG & TAG & 28 \\
\hline Cox2 & $\mathrm{H}$ & 4199-4885 & 687 & ATG & TAA & -2 \\
\hline tRNA-Asp & $\mathrm{H}$ & $4884-4951$ & 68 & & & 1 \\
\hline Atp8 & $\mathrm{H}$ & $4953-5111$ & 159 & ATG & TAA & 7 \\
\hline Atp6 & $\mathrm{H}$ & $5119-5814$ & 696 & ATG & TAA & 41 \\
\hline tRNA-Met & $\mathrm{L}$ & $5856-5922$ & 67 & & & 5 \\
\hline tRNA-Tyr & $\mathrm{L}$ & 5928-5994 & 67 & & & 1 \\
\hline tRNA-Cys & $\mathrm{L}$ & 5996-6061 & 66 & & & 0 \\
\hline tRNA-Trp & $\mathrm{L}$ & $6062-6127$ & 66 & & & 1 \\
\hline tRNA-Gln & $\mathrm{L}$ & 6129-6190 & 62 & & & 1 \\
\hline tRNA-Gly & $\mathrm{L}$ & $6192-6258$ & 67 & & & 13 \\
\hline tRNA-Glu & $\mathrm{L}$ & 6272-6336 & 65 & & & 0 \\
\hline $12 \mathrm{~s}$ & $\mathrm{H}$ & $6337-7292$ & 956 & & & 0 \\
\hline tRNA-Val & $\mathrm{H}$ & 7293-7360 & 68 & & & 0 \\
\hline $16 \mathrm{~s}$ & $\mathrm{H}$ & 7361-8711 & 1351 & & & 0 \\
\hline tRNA-Leu & $\mathrm{H}$ & $8712-8780$ & 69 & & & 2 \\
\hline tRNA-Leu & $\mathrm{H}$ & 8783-8851 & 69 & & & 0 \\
\hline Nad1 & $\mathrm{H}$ & $8852-9793$ & 942 & ATG & TAG & 6 \\
\hline tRNA-Pro & $\mathrm{H}$ & $9800-9867$ & 68 & & & 1 \\
\hline Nad6 & $\mathrm{H}$ & 9869-10369 & 501 & ATG & TAA & 4 \\
\hline Cytb & $\mathrm{H}$ & $10374-11513$ & 1140 & ATG & TAA & 11 \\
\hline tRNA-Ser & $\mathrm{H}$ & $11525-11590$ & 66 & & & 0 \\
\hline tRNA-Thr & $\mathrm{L}$ & 11591-11658 & 68 & & & 19 \\
\hline Nad4L & $\mathrm{H}$ & 11678-11974 & 297 & ATG & TAG & 11 \\
\hline Nad4 & $\mathrm{H}$ & 11986-13341 & 1356 & ATA & TAA & 1 \\
\hline tRNA-His & $\mathrm{H}$ & 13343-13407 & 65 & & & 0 \\
\hline Nad5 & $\mathrm{H}$ & 13408-15129 & 1722 & ATG & TAG & 41 \\
\hline tRNA-Phe & $\mathrm{H}$ & missing & - & & & - \\
\hline
\end{tabular}


Tritia incrassata-Spain 15,159 bp

\begin{tabular}{|c|c|c|c|c|c|c|}
\hline Gene & Strand & Location & $\begin{array}{l}\text { Size } \\
\text { (bp) }\end{array}$ & $\begin{array}{l}\text { Start } \\
\text { Codon }\end{array}$ & $\begin{array}{l}\text { Stop } \\
\text { codon }\end{array}$ & $\begin{array}{l}\text { Intergenic } \\
\text { nucleotides }\end{array}$ \\
\hline Cox3 & $\mathrm{H}$ & $1-775$ & incomplete & - & TAA & 14 \\
\hline tRNA-Lys & $\mathrm{H}$ & $790-854$ & 65 & & & 1 \\
\hline tRNA-Ala & $\mathrm{H}$ & $856-923$ & 68 & & & 9 \\
\hline tRNA-Arg & $\mathrm{H}$ & 933-1001 & 69 & & & 7 \\
\hline tRNA-Asn & $\mathrm{H}$ & $1009-1075$ & 67 & & & 15 \\
\hline tRNA-Ile & $\mathrm{H}$ & $1091-1157$ & 67 & & & 3 \\
\hline $\mathrm{Nad} 3$ & $\mathrm{H}$ & $1161-1514$ & 354 & ATG & TAA & 0 \\
\hline tRNA-Ser & $\mathrm{H}$ & $1515-1582$ & 68 & & & 0 \\
\hline $\mathrm{Nad} 2$ & $\mathrm{H}$ & 1583-2637 & 1055 & ATG & $\mathrm{TA}$ & 0 \\
\hline Cox1 & $\mathrm{H}$ & 2638-4173 & 1536 & ATG & TAG & 27 \\
\hline Cox2 & $\mathrm{H}$ & $4201-4887$ & 687 & ATG & TAA & -2 \\
\hline tRNA-Asp & $\mathrm{H}$ & $4886-4953$ & 68 & & & 1 \\
\hline Atp8 & $\mathrm{H}$ & $4955-5113$ & 159 & ATG & TAA & 7 \\
\hline Atp6 & $\mathrm{H}$ & $5121-5816$ & 696 & ATG & TAA & 41 \\
\hline tRNA-Met & $\mathrm{L}$ & $5858-5924$ & 67 & & & 5 \\
\hline tRNA-Tyr & $\mathrm{L}$ & $5930-5996$ & 67 & & & 1 \\
\hline tRNA-Cys & $\mathrm{L}$ & 5998-6062 & 65 & & & 0 \\
\hline tRNA-Trp & $\mathrm{L}$ & $6063-6128$ & 66 & & & 1 \\
\hline tRNA-Gln & $\mathrm{L}$ & $6130-6191$ & 62 & & & 1 \\
\hline tRNA-Gly & $\mathrm{L}$ & $6193-6259$ & 67 & & & 13 \\
\hline tRNA-Glu & $\mathrm{L}$ & 6273-6337 & 65 & & & 0 \\
\hline $12 \mathrm{~s}$ & $\mathrm{H}$ & 6338-7293 & 956 & & & 0 \\
\hline tRNA-Val & $\mathrm{H}$ & $7294-7361$ & 68 & & & 0 \\
\hline $16 \mathrm{~s}$ & $\mathrm{H}$ & $7362-8712$ & 1351 & & & 0 \\
\hline tRNA-Leu & $\mathrm{H}$ & 8713-8781 & 69 & & & 2 \\
\hline tRNA-Leu & $\mathrm{H}$ & 8784-8852 & 69 & & & 0 \\
\hline Nad1 & $\mathrm{H}$ & 8853-9794 & 942 & ATG & TAG & 6 \\
\hline tRNA-Pro & $\mathrm{H}$ & $9801-9868$ & 68 & & & 1 \\
\hline Nad6 & $\mathrm{H}$ & $9870-10370$ & 501 & ATG & TAA & 5 \\
\hline Cytb & $\mathrm{H}$ & 10376-11515 & 1140 & ATG & TAA & 11 \\
\hline tRNA-Ser & $\mathrm{H}$ & 11527-11591 & 65 & & & 0 \\
\hline tRNA-Thr & $\mathrm{L}$ & 11592-11659 & 68 & & & 19 \\
\hline Nad4L & $\mathrm{H}$ & 11679-11975 & 297 & ATG & TAG & 11 \\
\hline Nad4 & $\mathrm{H}$ & 11987-13342 & 1356 & ATA & TAA & 1 \\
\hline tRNA-His & $\mathrm{H}$ & 13344-13408 & 65 & & & 0 \\
\hline Nad5 & $\mathrm{H}$ & 13409-15130 & 1722 & ATG & TAG & 29 \\
\hline tRNA-Phe & $\mathrm{H}$ & missing & - & & & - \\
\hline
\end{tabular}


Tritia mutabilis 15,148 bp

\begin{tabular}{|c|c|c|c|c|c|c|}
\hline Gene & Strand & Location & $\begin{array}{l}\text { Size } \\
\text { (bp) }\end{array}$ & $\begin{array}{l}\text { Start } \\
\text { Codon }\end{array}$ & $\begin{array}{l}\text { Stop } \\
\text { codon }\end{array}$ & $\begin{array}{l}\text { Intergenic } \\
\text { nucleotides }\end{array}$ \\
\hline Cox3 & $\mathrm{H}$ & $1-750$ & incomplete & - & TAA & 15 \\
\hline tRNA-Lys & $\mathrm{H}$ & $766-830$ & 65 & & & 1 \\
\hline tRNA-Ala & $\mathrm{H}$ & 832-899 & 68 & & & 7 \\
\hline tRNA-Arg & $\mathrm{H}$ & $907-975$ & 69 & & & 10 \\
\hline tRNA-Asn & $\mathrm{H}$ & $986-1053$ & 68 & & & 16 \\
\hline tRNA-Ile & $\mathrm{H}$ & $1070-1137$ & 68 & & & 3 \\
\hline Nad3 & $\mathrm{H}$ & $1141-1494$ & 354 & ATG & TAA & 0 \\
\hline tRNA-Ser & $\mathrm{H}$ & $1495-1562$ & 68 & & & 0 \\
\hline Nad2 & $\mathrm{H}$ & $1563-2617$ & 1055 & ATG & $\mathrm{TA}$ & 0 \\
\hline Cox1 & $\mathrm{H}$ & $2618-4153$ & 1536 & ATG & TAA & 28 \\
\hline Cox2 & $\mathrm{H}$ & $4182-4868$ & 687 & ATG & TAA & -2 \\
\hline tRNA-Asp & $\mathrm{H}$ & $4867-4934$ & 68 & & & 1 \\
\hline Atp8 & $\mathrm{H}$ & 4936-5094 & 159 & ATG & TAA & 7 \\
\hline Atp6 & $\mathrm{H}$ & $5102-5797$ & 696 & ATG & TAG & 42 \\
\hline tRNA-Met & $\mathrm{L}$ & 5840-5906 & 67 & & & 2 \\
\hline tRNA-Tyr & $\mathrm{L}$ & 5909-5975 & 67 & & & 1 \\
\hline tRNA-Cys & $\mathrm{L}$ & $5977-6042$ & 66 & & & 0 \\
\hline tRNA-Trp & $\mathrm{L}$ & 6043-6108 & 66 & & & 1 \\
\hline tRNA-Gln & $\mathrm{L}$ & $6110-6171$ & 62 & & & 1 \\
\hline tRNA-Gly & $\mathrm{L}$ & 6173-6239 & 67 & & & 14 \\
\hline tRNA-Glu & $\mathrm{L}$ & 6254-6318 & 65 & & & 0 \\
\hline $12 \mathrm{~s}$ & $\mathrm{H}$ & $6319-7278$ & 960 & & & 0 \\
\hline tRNA-Val & $\mathrm{H}$ & $7279-7346$ & 68 & & & 0 \\
\hline $16 \mathrm{~s}$ & $\mathrm{H}$ & 7347-8699 & 1353 & & & 0 \\
\hline tRNA-Leu & $\mathrm{H}$ & $8700-8768$ & 69 & & & 2 \\
\hline tRNA-Leu & $\mathrm{H}$ & 8771-8839 & 69 & & & 0 \\
\hline Nad1 & $\mathrm{H}$ & $8840-9781$ & 942 & ATG & TAA & 6 \\
\hline tRNA-Pro & $\mathrm{H}$ & 9788-9855 & 68 & & & 1 \\
\hline Nad6 & $\mathrm{H}$ & $9857-10357$ & 501 & ATG & TAG & 5 \\
\hline Cytb & $\mathrm{H}$ & 10363-11502 & 1140 & ATG & TAA & 10 \\
\hline tRNA-Ser & $\mathrm{H}$ & 11513-11577 & 65 & & & 0 \\
\hline tRNA-Thr & $\mathrm{L}$ & 11578-11645 & 68 & & & 21 \\
\hline Nad4L & $\mathrm{H}$ & $11667-11963$ & 297 & ATG & TAG & 11 \\
\hline Nad4 & $\mathrm{H}$ & $11975-13330$ & 1356 & ATA & TAG & -1 \\
\hline tRNA-His & $\mathrm{H}$ & 13330-13395 & 66 & & & 1 \\
\hline Nad5 & $\mathrm{H}$ & 13397-15118 & 1722 & ATG & TAG & 30 \\
\hline tRNA-Phe & $\mathrm{H}$ & missing & - & & & - \\
\hline
\end{tabular}


Tritia neritea 15,179 bp

\begin{tabular}{|c|c|c|c|c|c|c|}
\hline Gene & Strand & Location & $\begin{array}{l}\text { Size } \\
\text { (bp) }\end{array}$ & $\begin{array}{l}\text { Start } \\
\text { Codon }\end{array}$ & $\begin{array}{l}\text { Stop } \\
\text { codon }\end{array}$ & $\begin{array}{l}\text { Intergenic } \\
\text { nucleotides }\end{array}$ \\
\hline Cox3 & $\mathrm{H}$ & $1-771$ & incomplete & - & TAA & 15 \\
\hline tRNA-Lys & $\mathrm{H}$ & $787-851$ & 65 & & & 0 \\
\hline tRNA-Ala & $\mathrm{H}$ & 852-919 & 68 & & & 9 \\
\hline tRNA-Arg & $\mathrm{H}$ & $929-997$ & 69 & & & 16 \\
\hline tRNA-Asn & $\mathrm{H}$ & 1014-1081 & 68 & & & 18 \\
\hline tRNA-Ile & $\mathrm{H}$ & $1100-1167$ & 68 & & & 3 \\
\hline $\mathrm{Nad} 3$ & $\mathrm{H}$ & $1171-1524$ & 354 & ATG & TAA & 0 \\
\hline tRNA-Ser & $\mathrm{H}$ & $1525-1592$ & 68 & & & 0 \\
\hline $\mathrm{Nad} 2$ & $\mathrm{H}$ & 1593-2647 & 1055 & ATG & $\mathrm{TA}$ & 0 \\
\hline Cox1 & $\mathrm{H}$ & 2648-4183 & 1536 & ATG & TAA & 28 \\
\hline Cox2 & $\mathrm{H}$ & $4212-4898$ & 687 & ATG & TAA & -2 \\
\hline tRNA-Asp & $\mathrm{H}$ & $4897-4964$ & 68 & & & 1 \\
\hline Atp8 & $\mathrm{H}$ & $4966-5124$ & 159 & ATG & TAA & 7 \\
\hline Atp6 & $\mathrm{H}$ & $5132-5827$ & 696 & ATG & TAA & 41 \\
\hline tRNA-Met & $\mathrm{L}$ & $5869-5935$ & 67 & & & 3 \\
\hline tRNA-Tyr & $\mathrm{L}$ & $5939-6006$ & 68 & & & 1 \\
\hline tRNA-Cys & $\mathrm{L}$ & $6008-6071$ & 64 & & & 0 \\
\hline tRNA-Trp & $\mathrm{L}$ & $6072-6137$ & 66 & & & 1 \\
\hline tRNA-Gln & $\mathrm{L}$ & $6139-6200$ & 62 & & & 1 \\
\hline tRNA-Gly & $\mathrm{L}$ & $6202-6268$ & 67 & & & 11 \\
\hline tRNA-Glu & $\mathrm{L}$ & $6280-6344$ & 65 & & & 0 \\
\hline $12 \mathrm{~s}$ & $\mathrm{H}$ & $6345-7300$ & 956 & & & 0 \\
\hline tRNA-Val & $\mathrm{H}$ & 7301-7368 & 68 & & & 0 \\
\hline $16 \mathrm{~s}$ & $\mathrm{H}$ & 7369-8720 & 1352 & & & 0 \\
\hline tRNA-Leu & $\mathrm{H}$ & 8721-8789 & 69 & & & 2 \\
\hline tRNA-Leu & $\mathrm{H}$ & $8792-8860$ & 69 & & & 0 \\
\hline Nad1 & $\mathrm{H}$ & 8861-9802 & 942 & ATG & TAA & 5 \\
\hline tRNA-Pro & $\mathrm{H}$ & $9808-9875$ & 68 & & & 1 \\
\hline Nad6 & $\mathrm{H}$ & $9877-10377$ & 501 & ATG & TAA & 10 \\
\hline Cytb & $\mathrm{H}$ & 10388-11527 & 1140 & ATG & TAA & 8 \\
\hline tRNA-Ser & $\mathrm{H}$ & $11536-11600$ & 65 & & & 0 \\
\hline tRNA-Thr & $\mathrm{L}$ & 11601-11667 & 67 & & & 22 \\
\hline Nad4L & $\mathrm{H}$ & 11690-11986 & 297 & ATG & TAG & 11 \\
\hline Nad4 & $\mathrm{H}$ & 11998-13353 & 1356 & ATA & TAG & -1 \\
\hline tRNA-His & $\mathrm{H}$ & 13353-13421 & 69 & & & 1 \\
\hline Nad5 & $\mathrm{H}$ & 13423-15144 & 1722 & ATG & TAG & 35 \\
\hline tRNA-Phe & $\mathrm{H}$ & missing & - & & & - \\
\hline
\end{tabular}


Tritia nitida 15,157 bp

\begin{tabular}{|c|c|c|c|c|c|c|}
\hline Gene & Strand & Location & $\begin{array}{l}\text { Size } \\
\text { (bp) }\end{array}$ & $\begin{array}{l}\text { Start } \\
\text { Codon }\end{array}$ & $\begin{array}{l}\text { Stop } \\
\text { codon }\end{array}$ & $\begin{array}{l}\text { Intergenic } \\
\text { nucleotides }\end{array}$ \\
\hline Cox3 & $\mathrm{H}$ & $1-750$ & incomplete & - & TAA & 12 \\
\hline tRNA-Lys & $\mathrm{H}$ & $763-827$ & 65 & & & 1 \\
\hline tRNA-Ala & $\mathrm{H}$ & 829-898 & 70 & & & 6 \\
\hline tRNA-Arg & $\mathrm{H}$ & $905-975$ & 71 & & & 8 \\
\hline tRNA-Asn & $\mathrm{H}$ & $984-1051$ & 68 & & & 20 \\
\hline tRNA-Ile & $\mathrm{H}$ & 1072-1139 & 68 & & & 3 \\
\hline $\mathrm{Nad} 3$ & $\mathrm{H}$ & $1143-1496$ & 354 & ATG & TAG & 0 \\
\hline tRNA-Ser & $\mathrm{H}$ & $1497-1564$ & 68 & & & 0 \\
\hline $\mathrm{Nad} 2$ & $\mathrm{H}$ & $1565-2619$ & 1055 & ATG & $\mathrm{TA}$ & 0 \\
\hline Cox1 & $\mathrm{H}$ & $2620-4155$ & 1536 & ATG & TAA & 26 \\
\hline Cox2 & $\mathrm{H}$ & $4182-4868$ & 687 & ATG & TAA & -1 \\
\hline tRNA-Asp & $\mathrm{H}$ & 4868-4935 & 68 & & & 1 \\
\hline Atp8 & $\mathrm{H}$ & 4937-5095 & 159 & ATG & TAA & 7 \\
\hline Atp6 & $\mathrm{H}$ & $5103-5798$ & 696 & ATG & TAG & 43 \\
\hline tRNA-Met & $\mathrm{L}$ & $5842-5908$ & 67 & & & 3 \\
\hline tRNA-Tyr & $\mathrm{L}$ & $5912-5982$ & 71 & & & -1 \\
\hline tRNA-Cys & $\mathrm{L}$ & $5982-6045$ & 64 & & & 0 \\
\hline tRNA-Trp & $\mathrm{L}$ & 6046-6111 & 66 & & & -3 \\
\hline tRNA-Gln & $\mathrm{L}$ & $6109-6175$ & 67 & & & -1 \\
\hline tRNA-Gly & $\mathrm{L}$ & $6175-6243$ & 69 & & & 14 \\
\hline tRNA-Glu & $\mathrm{L}$ & 6258-6322 & 65 & & & 0 \\
\hline $12 \mathrm{~s}$ & $\mathrm{H}$ & $6323-7282$ & 960 & & & 0 \\
\hline tRNA-Val & $\mathrm{H}$ & $7283-7349$ & 67 & & & 0 \\
\hline $16 \mathrm{~s}$ & $\mathrm{H}$ & $7350-8701$ & 1352 & & & 0 \\
\hline tRNA-Leu & $\mathrm{H}$ & $8702-8770$ & 69 & & & 1 \\
\hline tRNA-Leu & $\mathrm{H}$ & $8772-8840$ & 69 & & & 0 \\
\hline Nad1 & $\mathrm{H}$ & $8841-9782$ & 942 & ATG & TAA & 5 \\
\hline tRNA-Pro & $\mathrm{H}$ & $9788-9855$ & 68 & & & 1 \\
\hline Nad6 & $\mathrm{H}$ & $9857-10357$ & 501 & ATG & TAA & 6 \\
\hline Cytb & $\mathrm{H}$ & $10364-11503$ & 1140 & ATG & TAA & 8 \\
\hline tRNA-Ser & $\mathrm{H}$ & $11512-11576$ & 65 & & & 3 \\
\hline tRNA-Thr & $\mathrm{L}$ & 11580-11649 & 70 & & & 18 \\
\hline Nad4L & $\mathrm{H}$ & 11668-11964 & 297 & ATG & TAG & 11 \\
\hline Nad4 & $\mathrm{H}$ & 11976-13331 & 1356 & ATA & TAG & -1 \\
\hline tRNA-His & $\mathrm{H}$ & 13331-13396 & 66 & & & 1 \\
\hline Nad5 & $\mathrm{H}$ & 13398-15119 & 1722 & ATG & TAG & 38 \\
\hline tRNA-Phe & $\mathrm{H}$ & missing & - & & & - \\
\hline
\end{tabular}


Tritia pallaryana 15,144 bp

\begin{tabular}{|c|c|c|c|c|c|c|}
\hline Gene & Strand & Location & $\begin{array}{l}\text { Size } \\
\text { (bp) }\end{array}$ & $\begin{array}{l}\text { Start } \\
\text { Codon }\end{array}$ & $\begin{array}{l}\text { Stop } \\
\text { codon }\end{array}$ & $\begin{array}{l}\text { Intergenic } \\
\text { nucleotides }\end{array}$ \\
\hline Cox3 & $\mathrm{H}$ & $1-753$ & incomplete & - & TAG & 15 \\
\hline tRNA-Lys & $\mathrm{H}$ & 769-833 & 65 & & & 1 \\
\hline tRNA-Ala & $\mathrm{H}$ & 835-902 & 68 & & & 9 \\
\hline tRNA-Arg & $\mathrm{H}$ & $912-980$ & 69 & & & 5 \\
\hline tRNA-Asn & $\mathrm{H}$ & $986-1053$ & 68 & & & 15 \\
\hline tRNA-Ile & $\mathrm{H}$ & $1069-1136$ & 68 & & & 3 \\
\hline Nad3 & $\mathrm{H}$ & $1140-1493$ & 354 & ATG & TAA & 0 \\
\hline tRNA-Ser & $\mathrm{H}$ & 1494-1561 & 68 & & & 0 \\
\hline Nad2 & $\mathrm{H}$ & $1562-2616$ & 1055 & ATG & $\mathrm{TA}$ & 0 \\
\hline Cox1 & $\mathrm{H}$ & $2617-4152$ & 1536 & ATG & TAA & 29 \\
\hline Cox2 & $\mathrm{H}$ & $4182-4868$ & 687 & ATG & TAA & -2 \\
\hline tRNA-Asp & $\mathrm{H}$ & $4867-4934$ & 68 & & & 1 \\
\hline Atp8 & $\mathrm{H}$ & 4936-5094 & 159 & ATG & TAA & 7 \\
\hline Atp6 & $\mathrm{H}$ & $5102-5797$ & 696 & ATG & TAA & 38 \\
\hline tRNA-Met & $\mathrm{L}$ & 5836-5902 & 67 & & & 3 \\
\hline tRNA-Tyr & $\mathrm{L}$ & 5906-5973 & 68 & & & 1 \\
\hline tRNA-Cys & $\mathrm{L}$ & $5975-6039$ & 65 & & & 0 \\
\hline tRNA-Trp & $\mathrm{L}$ & 6040-6105 & 66 & & & -3 \\
\hline tRNA-Gln & $\mathrm{L}$ & 6103-6169 & 67 & & & -1 \\
\hline tRNA-Gly & $\mathrm{L}$ & 6169-6238 & 70 & & & 10 \\
\hline tRNA-Glu & $\mathrm{L}$ & $6249-6313$ & 65 & & & 0 \\
\hline $12 \mathrm{~s}$ & $\mathrm{H}$ & $6314-7271$ & 958 & & & 0 \\
\hline tRNA-Val & $\mathrm{H}$ & $7272-7339$ & 68 & & & 0 \\
\hline $16 \mathrm{~s}$ & $\mathrm{H}$ & $7340-8690$ & 1351 & & & 0 \\
\hline tRNA-Leu & $\mathrm{H}$ & 8691-8762 & 72 & & & 1 \\
\hline tRNA-Leu & $\mathrm{H}$ & 8764-8834 & 71 & & & -1 \\
\hline Nad1 & $\mathrm{H}$ & 8834-9775 & 942 & ATG & TAA & 6 \\
\hline tRNA-Pro & $\mathrm{H}$ & $9782-9849$ & 68 & & & 1 \\
\hline Nad6 & $\mathrm{H}$ & $9851-10351$ & 501 & ATG & TAG & 5 \\
\hline Cytb & $\mathrm{H}$ & $10357-11496$ & 1140 & ATG & TAA & 10 \\
\hline tRNA-Ser & $\mathrm{H}$ & $11507-11570$ & 64 & & & -1 \\
\hline tRNA-Thr & $\mathrm{L}$ & $11570-11636$ & 67 & & & 19 \\
\hline Nad4L & $\mathrm{H}$ & 11656-11952 & 297 & ATG & TAG & 11 \\
\hline Nad4 & $\mathrm{H}$ & 11964-13319 & 1356 & ATA & TAG & -1 \\
\hline tRNA-His & $\mathrm{H}$ & 13319-13383 & 65 & & & 0 \\
\hline Nad5 & $\mathrm{H}$ & 13384-15105 & 1722 & ATG & TAG & 39 \\
\hline tRNA-Phe & $\mathrm{H}$ & missing & - & & & - \\
\hline
\end{tabular}


Tritia pellucida 15,175 bp

\begin{tabular}{|c|c|c|c|c|c|c|}
\hline Gene & Strand & Location & $\begin{array}{l}\text { Size } \\
\text { (bp) }\end{array}$ & $\begin{array}{l}\text { Start } \\
\text { Codon }\end{array}$ & $\begin{array}{l}\text { Stop } \\
\text { codon }\end{array}$ & $\begin{array}{l}\text { Intergenic } \\
\text { nucleotides }\end{array}$ \\
\hline Cox3 & $\mathrm{H}$ & $1-771$ & incomplete & - & TAA & 15 \\
\hline tRNA-Lys & $\mathrm{H}$ & $787-851$ & 65 & & & 0 \\
\hline tRNA-Ala & $\mathrm{H}$ & 852-919 & 68 & & & 9 \\
\hline tRNA-Arg & $\mathrm{H}$ & $929-997$ & 69 & & & 16 \\
\hline tRNA-Asn & $\mathrm{H}$ & 1014-1081 & 68 & & & 18 \\
\hline tRNA-Ile & $\mathrm{H}$ & $1100-1167$ & 68 & & & 3 \\
\hline $\mathrm{Nad} 3$ & $\mathrm{H}$ & $1171-1524$ & 354 & ATG & TAA & 0 \\
\hline tRNA-Ser & $\mathrm{H}$ & $1525-1592$ & 68 & & & 0 \\
\hline $\mathrm{Nad} 2$ & $\mathrm{H}$ & 1593-2647 & 1055 & ATG & $\mathrm{TA}$ & 0 \\
\hline Cox1 & $\mathrm{H}$ & 2648-4183 & 1536 & ATG & TAA & 28 \\
\hline Cox2 & $\mathrm{H}$ & $4212-4898$ & 687 & ATG & TAA & -2 \\
\hline tRNA-Asp & $\mathrm{H}$ & $4897-4964$ & 68 & & & 1 \\
\hline Atp8 & $\mathrm{H}$ & $4966-5124$ & 159 & ATG & TAA & 7 \\
\hline Atp6 & $\mathrm{H}$ & $5132-5827$ & 696 & ATG & TAA & 41 \\
\hline tRNA-Met & $\mathrm{L}$ & $5869-5935$ & 67 & & & 3 \\
\hline tRNA-Tyr & $\mathrm{L}$ & $5939-6006$ & 68 & & & 1 \\
\hline tRNA-Cys & $\mathrm{L}$ & $6008-6072$ & 65 & & & 0 \\
\hline tRNA-Trp & $\mathrm{L}$ & 6073-6138 & 66 & & & 1 \\
\hline tRNA-Gln & $\mathrm{L}$ & $6140-6201$ & 62 & & & 1 \\
\hline tRNA-Gly & $\mathrm{L}$ & $6203-6269$ & 67 & & & 11 \\
\hline tRNA-Glu & $\mathrm{L}$ & $6281-6345$ & 65 & & & 0 \\
\hline $12 \mathrm{~s}$ & $\mathrm{H}$ & 6346-7301 & 956 & & & 0 \\
\hline tRNA-Val & $\mathrm{H}$ & $7202-7369$ & 68 & & & 0 \\
\hline $16 \mathrm{~s}$ & $\mathrm{H}$ & $7370-8718$ & 1349 & & & 0 \\
\hline tRNA-Leu & $\mathrm{H}$ & 8719-8787 & 69 & & & 2 \\
\hline tRNA-Leu & $\mathrm{H}$ & 8790-8858 & 69 & & & 0 \\
\hline Nad1 & $\mathrm{H}$ & $8859-9800$ & 942 & ATG & TAA & 5 \\
\hline tRNA-Pro & $\mathrm{H}$ & $9806-9873$ & 68 & & & 1 \\
\hline Nad6 & $\mathrm{H}$ & $9875-10375$ & 501 & ATG & TAA & 10 \\
\hline Cytb & $\mathrm{H}$ & 10386-11525 & 1140 & ATG & TAA & 8 \\
\hline tRNA-Ser & $\mathrm{H}$ & 11534-11598 & 65 & & & 0 \\
\hline tRNA-Thr & $\mathrm{L}$ & 11599-11665 & 67 & & & 22 \\
\hline Nad4L & $\mathrm{H}$ & 11688-11984 & 297 & ATG & TAG & 11 \\
\hline Nad4 & $\mathrm{H}$ & 11996-13351 & 1356 & ATA & TAG & -1 \\
\hline tRNA-His & $\mathrm{H}$ & 13351-13417 & 67 & & & 1 \\
\hline Nad5 & $\mathrm{H}$ & $13419-15140$ & 1722 & ATG & TAG & 35 \\
\hline tRNA-Phe & $\mathrm{H}$ & missing & - & & & - \\
\hline
\end{tabular}


Tritia pfeifferi 15,142 bp

\begin{tabular}{|c|c|c|c|c|c|c|}
\hline Gene & Strand & Location & $\begin{array}{l}\text { Size } \\
\text { (bp) }\end{array}$ & $\begin{array}{l}\text { Start } \\
\text { Codon }\end{array}$ & $\begin{array}{l}\text { Stop } \\
\text { codon }\end{array}$ & $\begin{array}{l}\text { Intergenic } \\
\text { nucleotides }\end{array}$ \\
\hline Cox3 & $\mathrm{H}$ & $1-747$ & incomplete & - & TAA & 15 \\
\hline tRNA-Lys & $\mathrm{H}$ & $763-827$ & 65 & & & 0 \\
\hline tRNA-Ala & $\mathrm{H}$ & 828-895 & 68 & & & 5 \\
\hline tRNA-Arg & $\mathrm{H}$ & $901-969$ & 69 & & & 16 \\
\hline tRNA-Asn & $\mathrm{H}$ & $986-1053$ & 68 & & & 14 \\
\hline tRNA-Ile & $\mathrm{H}$ & 1068-1135 & 68 & & & 3 \\
\hline $\mathrm{Nad} 3$ & $\mathrm{H}$ & $1139-1492$ & 354 & ATG & TAA & 0 \\
\hline tRNA-Ser & $\mathrm{H}$ & $1493-1560$ & 68 & & & 0 \\
\hline $\mathrm{Nad} 2$ & $\mathrm{H}$ & $1561-2615$ & 1055 & ATG & $\mathrm{TA}$ & 0 \\
\hline Cox1 & $\mathrm{H}$ & 2616-4151 & 1536 & ATG & TAA & 28 \\
\hline Cox2 & $\mathrm{H}$ & $4180-4866$ & 687 & ATG & TAA & -2 \\
\hline tRNA-Asp & $\mathrm{H}$ & $4865-4932$ & 68 & & & 1 \\
\hline Atp8 & $\mathrm{H}$ & 4934-5092 & 159 & ATG & TAA & 8 \\
\hline Atp6 & $\mathrm{H}$ & $5101-5796$ & 696 & ATG & TAA & 42 \\
\hline tRNA-Met & $\mathrm{L}$ & 5839-5905 & 67 & & & 1 \\
\hline tRNA-Tyr & $\mathrm{L}$ & $5907-5974$ & 68 & & & 1 \\
\hline tRNA-Cys & $\mathrm{L}$ & $5976-6041$ & 66 & & & 0 \\
\hline tRNA-Trp & $\mathrm{L}$ & $6042-6107$ & 66 & & & 1 \\
\hline tRNA-Gln & $\mathrm{L}$ & $6109-6170$ & 62 & & & 1 \\
\hline tRNA-Gly & $\mathrm{L}$ & $6172-6238$ & 67 & & & 12 \\
\hline tRNA-Glu & $\mathrm{L}$ & 6251-6315 & 65 & & & 0 \\
\hline $12 \mathrm{~s}$ & $\mathrm{H}$ & $6316-7271$ & 956 & & & 0 \\
\hline tRNA-Val & $\mathrm{H}$ & $7272-7339$ & 68 & & & 0 \\
\hline $16 \mathrm{~s}$ & $\mathrm{H}$ & $7340-8691$ & 1352 & & & 0 \\
\hline tRNA-Leu & $\mathrm{H}$ & $8692-8760$ & 69 & & & 3 \\
\hline tRNA-Leu & $\mathrm{H}$ & 8764-8832 & 69 & & & 0 \\
\hline Nad1 & $\mathrm{H}$ & $8833-9774$ & 942 & ATG & TAA & 6 \\
\hline tRNA-Pro & $\mathrm{H}$ & $9781-9848$ & 68 & & & 1 \\
\hline Nad6 & $\mathrm{H}$ & $9850-10350$ & 501 & ATG & TAA & 5 \\
\hline Cytb & $\mathrm{H}$ & 10356-11495 & 1140 & ATG & TAA & 10 \\
\hline tRNA-Ser & $\mathrm{H}$ & $11506-11570$ & 65 & & & 0 \\
\hline tRNA-Thr & $\mathrm{L}$ & 11571-11638 & 68 & & & 21 \\
\hline Nad4L & $\mathrm{H}$ & $11660-11956$ & 297 & ATG & TAG & 11 \\
\hline Nad4 & $\mathrm{H}$ & 11968-13323 & 1356 & ATA & TAG & -1 \\
\hline tRNA-His & $\mathrm{H}$ & 13323-13388 & 66 & & & 1 \\
\hline Nad5 & $\mathrm{H}$ & 13390-15111 & 1722 & ATG & TAG & 31 \\
\hline tRNA-Phe & $\mathrm{H}$ & missing & - & & & - \\
\hline
\end{tabular}


Tritia varicosa 15,142 bp

\begin{tabular}{|c|c|c|c|c|c|c|}
\hline Gene & Strand & Location & $\begin{array}{l}\text { Size } \\
\text { (bp) }\end{array}$ & $\begin{array}{l}\text { Start } \\
\text { Codon }\end{array}$ & $\begin{array}{l}\text { Stop } \\
\text { codon }\end{array}$ & $\begin{array}{l}\text { Intergenic } \\
\text { nucleotides }\end{array}$ \\
\hline Cox3 & $\mathrm{H}$ & $1-762$ & incomplete & - & TAA & 18 \\
\hline tRNA-Lys & $\mathrm{H}$ & 781-847 & 67 & & & -1 \\
\hline tRNA-Ala & $\mathrm{H}$ & $847-916$ & 70 & & & 0 \\
\hline tRNA-Arg & $\mathrm{H}$ & $917-985$ & 69 & & & 20 \\
\hline tRNA-Asn & $\mathrm{H}$ & $1006-1072$ & 67 & & & 14 \\
\hline tRNA-Ile & $\mathrm{H}$ & $1087-1154$ & 68 & & & 3 \\
\hline $\mathrm{Nad} 3$ & $\mathrm{H}$ & $1158-1511$ & 354 & ATG & TAA & 0 \\
\hline tRNA-Ser & $\mathrm{H}$ & $1512-1579$ & 68 & & & 0 \\
\hline $\mathrm{Nad} 2$ & $\mathrm{H}$ & $1580-2634$ & 1055 & ATG & $\mathrm{TA}$ & 0 \\
\hline Cox1 & $\mathrm{H}$ & $2635-4170$ & 1536 & ATG & TAG & 22 \\
\hline Cox2 & $\mathrm{H}$ & $4193-4879$ & 687 & ATG & TAA & -2 \\
\hline tRNA-Asp & $\mathrm{H}$ & $4878-4945$ & 68 & & & 1 \\
\hline Atp8 & $\mathrm{H}$ & 4947-5105 & 159 & ATG & TAA & 7 \\
\hline Atp6 & $\mathrm{H}$ & 5113-5808 & 696 & ATG & TAA & 41 \\
\hline tRNA-Met & $\mathrm{L}$ & $5850-5916$ & 67 & & & 2 \\
\hline tRNA-Tyr & $\mathrm{L}$ & 5919-5985 & 67 & & & 1 \\
\hline tRNA-Cys & $\mathrm{L}$ & $5987-6051$ & 65 & & & 0 \\
\hline tRNA-Trp & $\mathrm{L}$ & $6052-6117$ & 66 & & & -3 \\
\hline tRNA-Gln & $\mathrm{L}$ & $6115-6181$ & 67 & & & 0 \\
\hline tRNA-Gly & $\mathrm{L}$ & $6182-6248$ & 67 & & & 13 \\
\hline tRNA-Glu & $\mathrm{L}$ & $6262-6326$ & 65 & & & 0 \\
\hline $12 \mathrm{~s}$ & $\mathrm{H}$ & $6327-7283$ & 957 & & & 0 \\
\hline tRNA-Val & $\mathrm{H}$ & $7284-7351$ & 68 & & & 0 \\
\hline $16 \mathrm{~s}$ & $\mathrm{H}$ & $7352-8701$ & 1350 & & & 0 \\
\hline tRNA-Leu & $\mathrm{H}$ & $8702-8770$ & 69 & & & 2 \\
\hline tRNA-Leu & $\mathrm{H}$ & 8773-8841 & 69 & & & 0 \\
\hline Nad1 & $\mathrm{H}$ & $8842-9783$ & 942 & ATG & TAA & 5 \\
\hline tRNA-Pro & $\mathrm{H}$ & $9789-9856$ & 68 & & & 1 \\
\hline Nad6 & $\mathrm{H}$ & 9858-10358 & 501 & ATG & TAA & 2 \\
\hline Cytb & $\mathrm{H}$ & $10361-11500$ & 1140 & ATG & TAA & 8 \\
\hline tRNA-Ser & $\mathrm{H}$ & 11509-11573 & 65 & & & -1 \\
\hline tRNA-Thr & $\mathrm{L}$ & 11573-11641 & 69 & & & 20 \\
\hline Nad4L & $\mathrm{H}$ & 11662-11958 & 297 & ATG & TAG & 11 \\
\hline Nad4 & $\mathrm{H}$ & 11970-13325 & 1356 & ATA & TAG & -1 \\
\hline tRNA-His & $\mathrm{H}$ & 13325-13389 & 65 & & & 1 \\
\hline Nad5 & $\mathrm{H}$ & 13390-15111 & 1722 & ATG & TAG & 31 \\
\hline tRNA-Phe & $\mathrm{H}$ & missing & - & & & - \\
\hline
\end{tabular}


Tritia tenuicosta 15,169 bp

\begin{tabular}{|c|c|c|c|c|c|c|}
\hline Gene & Strand & Location & $\begin{array}{l}\text { Size } \\
\text { (bp) }\end{array}$ & $\begin{array}{l}\text { Start } \\
\text { Codon }\end{array}$ & $\begin{array}{l}\text { Stop } \\
\text { codon }\end{array}$ & $\begin{array}{l}\text { Intergenic } \\
\text { nucleotides }\end{array}$ \\
\hline Cox3 & $\mathrm{H}$ & $1-770$ & incomplete & - & TAA & 12 \\
\hline tRNA-Lys & $\mathrm{H}$ & $783-848$ & 66 & & & 1 \\
\hline tRNA-Ala & $\mathrm{H}$ & 850-919 & 70 & & & 8 \\
\hline tRNA-Arg & $\mathrm{H}$ & 928-996 & 69 & & & 11 \\
\hline tRNA-Asn & $\mathrm{H}$ & $1008-1074$ & 67 & & & 15 \\
\hline tRNA-Ile & $\mathrm{H}$ & $1090-1157$ & 68 & & & 3 \\
\hline $\mathrm{Nad} 3$ & $\mathrm{H}$ & $1161-1514$ & 354 & ATG & TAA & -1 \\
\hline tRNA-Ser & $\mathrm{H}$ & $1514-1583$ & 70 & & & -1 \\
\hline $\mathrm{Nad} 2$ & $\mathrm{H}$ & 1583-2637 & 1055 & ATG & $\mathrm{TA}$ & 0 \\
\hline Cox1 & $\mathrm{H}$ & 2638-4173 & 1536 & ATG & TAA & 25 \\
\hline Cox2 & $\mathrm{H}$ & 4199-4885 & 687 & ATG & TAA & -2 \\
\hline tRNA-Asp & $\mathrm{H}$ & $4884-4951$ & 68 & & & 1 \\
\hline Atp8 & $\mathrm{H}$ & $4953-5111$ & 159 & ATG & TAA & 6 \\
\hline Atp6 & $\mathrm{H}$ & $5118-5813$ & 696 & ATG & TAA & 42 \\
\hline tRNA-Met & $\mathrm{L}$ & $5856-5922$ & 67 & & & 3 \\
\hline tRNA-Tyr & $\mathrm{L}$ & 5926-5996 & 71 & & & -1 \\
\hline tRNA-Cys & $\mathrm{L}$ & $5996-6060$ & 65 & & & 0 \\
\hline tRNA-Trp & $\mathrm{L}$ & 6061-6126 & 66 & & & -3 \\
\hline tRNA-Gln & $\mathrm{L}$ & 6124-6190 & 67 & & & 0 \\
\hline tRNA-Gly & $\mathrm{L}$ & 6191-6257 & 67 & & & 12 \\
\hline tRNA-Glu & $\mathrm{L}$ & $6270-6335$ & 65 & & & 0 \\
\hline $12 \mathrm{~s}$ & $\mathrm{H}$ & 6336-7296 & 961 & & & 0 \\
\hline tRNA-Val & $\mathrm{H}$ & $7297-7364$ & 68 & & & 0 \\
\hline $16 \mathrm{~s}$ & $\mathrm{H}$ & $7365-8716$ & 1352 & & & 0 \\
\hline tRNA-Leu & $\mathrm{H}$ & 8717-8785 & 69 & & & 1 \\
\hline tRNA-Leu & $\mathrm{H}$ & 8787-8857 & 71 & & & -1 \\
\hline Nad1 & $\mathrm{H}$ & $8857-9798$ & 942 & ATG & TAA & 4 \\
\hline tRNA-Pro & $\mathrm{H}$ & $9803-9870$ & 68 & & & 1 \\
\hline Nad6 & $\mathrm{H}$ & $9872-10372$ & 501 & ATG & TAA & 6 \\
\hline Cytb & $\mathrm{H}$ & 10379-11518 & 1140 & ATG & TAA & 11 \\
\hline tRNA-Ser & $\mathrm{H}$ & 11530-11593 & 64 & & & -1 \\
\hline tRNA-Thr & $\mathrm{L}$ & 11593-11662 & 70 & & & 24 \\
\hline Nad4L & $\mathrm{H}$ & 11687-11983 & 297 & ATG & TAG & 11 \\
\hline Nad4 & $\mathrm{H}$ & 11995-13350 & 1356 & ATA & TAG & -1 \\
\hline tRNA-His & $\mathrm{H}$ & $13350-13415$ & 66 & & & 1 \\
\hline Nad5 & $\mathrm{H}$ & 13417-15138 & 1722 & ATG & TAG & 31 \\
\hline tRNA-Phe & $\mathrm{H}$ & missing & - & & & - \\
\hline
\end{tabular}


Tritia unifasciata 15,168 bp

\begin{tabular}{|c|c|c|c|c|c|c|}
\hline Gene & Strand & Location & $\begin{array}{l}\text { Size } \\
\text { (bp) }\end{array}$ & $\begin{array}{l}\text { Start } \\
\text { Codon }\end{array}$ & $\begin{array}{l}\text { Stop } \\
\text { codon }\end{array}$ & $\begin{array}{l}\text { Intergenic } \\
\text { nucleotides }\end{array}$ \\
\hline Cox3 & $\mathrm{H}$ & $1-771$ & incomplete & - & TAG & 12 \\
\hline tRNA-Lys & $\mathrm{H}$ & 784-848 & 65 & & & 2 \\
\hline tRNA-Ala & $\mathrm{H}$ & 851-918 & 68 & & & 10 \\
\hline tRNA-Arg & $\mathrm{H}$ & $929-997$ & 69 & & & 9 \\
\hline tRNA-Asn & $\mathrm{H}$ & $1007-1074$ & 68 & & & 17 \\
\hline tRNA-Ile & $\mathrm{H}$ & $1092-1159$ & 68 & & & 3 \\
\hline $\mathrm{Nad} 3$ & $\mathrm{H}$ & $1163-1516$ & 354 & ATG & TAG & 0 \\
\hline tRNA-Ser & $\mathrm{H}$ & $1517-1584$ & 68 & & & 0 \\
\hline $\mathrm{Nad} 2$ & $\mathrm{H}$ & $1585-2639$ & 1055 & ATG & $\mathrm{TA}$ & 0 \\
\hline Cox1 & $\mathrm{H}$ & $2640-4175$ & 1536 & ATG & TAA & 25 \\
\hline Cox2 & $\mathrm{H}$ & $4201-4887$ & 687 & ATG & TAA & -2 \\
\hline tRNA-Asp & $\mathrm{H}$ & $4886-4953$ & 68 & & & 1 \\
\hline Atp8 & $\mathrm{H}$ & $4955-5113$ & 159 & ATG & TAA & 7 \\
\hline Atp6 & $\mathrm{H}$ & $5121-5816$ & 696 & ATG & TAA & 40 \\
\hline tRNA-Met & $\mathrm{L}$ & $5857-5923$ & 67 & & & 2 \\
\hline tRNA-Tyr & $\mathrm{L}$ & 5926-5992 & 67 & & & 1 \\
\hline tRNA-Cys & $\mathrm{L}$ & $5994-6057$ & 64 & & & 0 \\
\hline tRNA-Trp & $\mathrm{L}$ & $6058-6123$ & 66 & & & 1 \\
\hline tRNA-Gln & $\mathrm{L}$ & $6125-6186$ & 62 & & & 1 \\
\hline tRNA-Gly & $\mathrm{L}$ & 6188-6254 & 67 & & & 14 \\
\hline tRNA-Glu & $\mathrm{L}$ & 6269-6333 & 65 & & & 0 \\
\hline $12 \mathrm{~s}$ & $\mathrm{H}$ & 6334-7292 & 959 & & & 0 \\
\hline tRNA-Val & $\mathrm{H}$ & $7293-7360$ & 68 & & & 0 \\
\hline $16 \mathrm{~s}$ & $\mathrm{H}$ & 7361-8712 & 1352 & & & 0 \\
\hline tRNA-Leu & $\mathrm{H}$ & 8713-8781 & 69 & & & 2 \\
\hline tRNA-Leu & $\mathrm{H}$ & 8784-8852 & 69 & & & 0 \\
\hline Nad1 & $\mathrm{H}$ & 8853-9794 & 942 & ATG & TAA & 5 \\
\hline tRNA-Pro & $\mathrm{H}$ & $9800-9867$ & 68 & & & 1 \\
\hline Nad6 & $\mathrm{H}$ & 9869-10369 & 501 & ATG & TAA & 6 \\
\hline Cytb & $\mathrm{H}$ & 10376-11515 & 1140 & ATG & TAG & 11 \\
\hline tRNA-Ser & $\mathrm{H}$ & 11527-11591 & 65 & & & 0 \\
\hline tRNA-Thr & $\mathrm{L}$ & 11592-11659 & 68 & & & 21 \\
\hline Nad4L & $\mathrm{H}$ & 11681-11977 & 297 & ATG & TAG & 11 \\
\hline Nad4 & $\mathrm{H}$ & 11989-13344 & 1356 & ATA & TAG & -1 \\
\hline tRNA-His & $\mathrm{H}$ & 13344-13408 & 65 & & & 1 \\
\hline Nad5 & $\mathrm{H}$ & $13410-15131$ & 1722 & ATG & TAG & 37 \\
\hline tRNA-Phe & $\mathrm{H}$ & missing & - & & & - \\
\hline
\end{tabular}


Tritia vaucheri 15,153 bp

\begin{tabular}{|c|c|c|c|c|c|c|}
\hline Gene & Strand & Location & $\begin{array}{l}\text { Size } \\
\text { (bp) }\end{array}$ & $\begin{array}{l}\text { Start } \\
\text { Codon }\end{array}$ & $\begin{array}{l}\text { Stop } \\
\text { codon }\end{array}$ & $\begin{array}{l}\text { Intergenic } \\
\text { nucleotides }\end{array}$ \\
\hline Cox3 & $\mathrm{H}$ & $1-750$ & incomplete & - & TAA & 13 \\
\hline tRNA-Lys & $\mathrm{H}$ & 764-829 & 66 & & & 4 \\
\hline tRNA-Ala & $\mathrm{H}$ & 834-901 & 68 & & & 8 \\
\hline tRNA-Arg & $\mathrm{H}$ & $910-978$ & 69 & & & 5 \\
\hline tRNA-Asn & $\mathrm{H}$ & $984-1052$ & 69 & & & 8 \\
\hline tRNA-Ile & $\mathrm{H}$ & $1061-1128$ & 68 & & & 3 \\
\hline $\mathrm{Nad} 3$ & $\mathrm{H}$ & $1132-1485$ & 354 & ATG & TAA & 0 \\
\hline tRNA-Ser & $\mathrm{H}$ & $1486-1553$ & 68 & & & 0 \\
\hline $\mathrm{Nad} 2$ & $\mathrm{H}$ & $1554-2608$ & 1055 & ATG & $\mathrm{TA}$ & 0 \\
\hline Cox1 & $\mathrm{H}$ & $2609-4144$ & 1536 & ATG & TAA & 29 \\
\hline Cox2 & $\mathrm{H}$ & $4174-4860$ & 687 & ATG & TAA & -2 \\
\hline tRNA-Asp & $\mathrm{H}$ & $4859-4926$ & 68 & & & 1 \\
\hline Atp8 & $\mathrm{H}$ & 4928-5086 & 159 & ATG & TAA & 6 \\
\hline Atp6 & $\mathrm{H}$ & $5093-5788$ & 696 & ATG & TAG & 40 \\
\hline tRNA-Met & $\mathrm{L}$ & 5829-5895 & 67 & & & 8 \\
\hline tRNA-Tyr & $\mathrm{L}$ & $5904-5970$ & 67 & & & 1 \\
\hline tRNA-Cys & $\mathrm{L}$ & $5972-6035$ & 64 & & & 0 \\
\hline tRNA-Trp & $\mathrm{L}$ & 6036-6102 & 67 & & & 1 \\
\hline tRNA-Gln & $\mathrm{L}$ & 6104-6165 & 62 & & & 1 \\
\hline tRNA-Gly & $\mathrm{L}$ & $6167-6233$ & 67 & & & 13 \\
\hline tRNA-Glu & $\mathrm{L}$ & 6247-6311 & 65 & & & 0 \\
\hline $12 \mathrm{~s}$ & $\mathrm{H}$ & $6312-7264$ & 953 & & & 0 \\
\hline tRNA-Val & $\mathrm{H}$ & $7265-7332$ & 68 & & & 0 \\
\hline $16 \mathrm{~s}$ & $\mathrm{H}$ & 7333-8687 & 1355 & & & 0 \\
\hline tRNA-Leu & $\mathrm{H}$ & 8688-8756 & 69 & & & 4 \\
\hline tRNA-Leu & $\mathrm{H}$ & 8761-8829 & 69 & & & 0 \\
\hline Nad1 & $\mathrm{H}$ & $8830-9771$ & 942 & ATG & TAA & 6 \\
\hline tRNA-Pro & $\mathrm{H}$ & $9778-9846$ & 69 & & & 1 \\
\hline Nad6 & $\mathrm{H}$ & $9848-10348$ & 501 & ATG & TAA & 12 \\
\hline Cytb & $\mathrm{H}$ & $10361-11500$ & 1140 & ATG & TAA & 13 \\
\hline tRNA-Ser & $\mathrm{H}$ & $11514-11578$ & 65 & & & 0 \\
\hline tRNA-Thr & $\mathrm{L}$ & 11579-11644 & 66 & & & 20 \\
\hline Nad4L & $\mathrm{H}$ & 11665-11961 & 297 & ATG & TAG & 11 \\
\hline Nad4 & $\mathrm{H}$ & 11973-13328 & 1356 & CTT & TAG & -1 \\
\hline tRNA-His & $\mathrm{H}$ & 13328-13393 & 66 & & & 1 \\
\hline Nad5 & $\mathrm{H}$ & 13395-15116 & 1722 & ATG & TAG & 37 \\
\hline tRNA-Phe & $\mathrm{H}$ & missing & - & & & - \\
\hline
\end{tabular}


Tritia elata 15,167 bp

\begin{tabular}{|c|c|c|c|c|c|c|}
\hline Gene & Strand & Location & $\begin{array}{l}\text { Size } \\
\text { (bp) }\end{array}$ & $\begin{array}{l}\text { Start } \\
\text { Codon }\end{array}$ & $\begin{array}{l}\text { Stop } \\
\text { codon }\end{array}$ & $\begin{array}{l}\text { Intergenic } \\
\text { nucleotides }\end{array}$ \\
\hline Cox3 & $\mathrm{H}$ & $1-767$ & incomplete & - & TAA & 15 \\
\hline tRNA-Lys & $\mathrm{H}$ & $783-848$ & 66 & & & 1 \\
\hline tRNA-Ala & $\mathrm{H}$ & 850-919 & 70 & & & 8 \\
\hline tRNA-Arg & $\mathrm{H}$ & 928-996 & 69 & & & 6 \\
\hline tRNA-Asn & $\mathrm{H}$ & $1003-1070$ & 68 & & & 18 \\
\hline tRNA-Ile & $\mathrm{H}$ & $1089-1156$ & 68 & & & 3 \\
\hline $\mathrm{Nad} 3$ & $\mathrm{H}$ & $1160-1513$ & 354 & ATG & TAA & -1 \\
\hline tRNA-Ser & $\mathrm{H}$ & $1513-1582$ & 70 & & & -1 \\
\hline $\mathrm{Nad} 2$ & $\mathrm{H}$ & $1582-2636$ & 1055 & ATG & $\mathrm{TA}$ & 0 \\
\hline Cox1 & $\mathrm{H}$ & 2637-4172 & 1536 & ATG & TAA & 30 \\
\hline Cox2 & $\mathrm{H}$ & 4203-4889 & 687 & ATG & TAA & -2 \\
\hline tRNA-Asp & $\mathrm{H}$ & 4888-4955 & 68 & & & 1 \\
\hline Atp8 & $\mathrm{H}$ & 4957-5115 & 159 & ATG & TAA & 6 \\
\hline Atp6 & $\mathrm{H}$ & $5122-5817$ & 696 & ATG & TAG & 41 \\
\hline tRNA-Met & $\mathrm{L}$ & $5859-5925$ & 67 & & & 1 \\
\hline tRNA-Tyr & $\mathrm{L}$ & 5927-5996 & 70 & & & 5 \\
\hline tRNA-Cys & $\mathrm{L}$ & $6002-6066$ & 65 & & & 0 \\
\hline tRNA-Trp & $\mathrm{L}$ & $6067-6132$ & 66 & & & -3 \\
\hline tRNA-Gln & $\mathrm{L}$ & 6130-6196 & 67 & & & 0 \\
\hline tRNA-Gly & $\mathrm{L}$ & $6197-6263$ & 67 & & & 15 \\
\hline tRNA-Glu & $\mathrm{L}$ & $6279-6343$ & 65 & & & 0 \\
\hline $12 \mathrm{~s}$ & $\mathrm{H}$ & $6344-7295$ & 952 & & & 0 \\
\hline tRNA-Val & $\mathrm{H}$ & 7296-7363 & 68 & & & 0 \\
\hline $16 \mathrm{~s}$ & $\mathrm{H}$ & 7364-8715 & 1352 & & & 0 \\
\hline tRNA-Leu & $\mathrm{H}$ & 8716-8784 & 69 & & & 3 \\
\hline tRNA-Leu & $\mathrm{H}$ & 8788-8858 & 71 & & & -1 \\
\hline Nad1 & $\mathrm{H}$ & 8858-9799 & 942 & ATG & TAA & 6 \\
\hline tRNA-Pro & $\mathrm{H}$ & $9806-9873$ & 68 & & & 1 \\
\hline Nad6 & $\mathrm{H}$ & $9875-10375$ & 501 & ATG & TAA & 5 \\
\hline Cytb & $\mathrm{H}$ & $10381-11520$ & 1140 & ATG & TAA & 10 \\
\hline tRNA-Ser & $\mathrm{H}$ & 11531-11595 & 65 & & & -1 \\
\hline tRNA-Thr & $\mathrm{L}$ & 11595-11664 & 70 & & & 20 \\
\hline Nad4L & $\mathrm{H}$ & 11685-11981 & 297 & ATG & TAG & 11 \\
\hline Nad4 & $\mathrm{H}$ & 11993-13348 & 1356 & ATA & TAG & -1 \\
\hline tRNA-His & $\mathrm{H}$ & $13348-13413$ & 66 & & & 1 \\
\hline Nad5 & $\mathrm{H}$ & $13415-15136$ & 1722 & ATG & TAG & 31 \\
\hline tRNA-Phe & $\mathrm{H}$ & missing & - & & & - \\
\hline
\end{tabular}


Tritia ovoidea partial mt genome

\begin{tabular}{|c|c|c|c|c|c|c|}
\hline Gene & Strand & Location & $\begin{array}{l}\text { Size } \\
\text { (bp) }\end{array}$ & $\begin{array}{l}\text { Start } \\
\text { Codon }\end{array}$ & $\begin{array}{l}\text { Stop } \\
\text { codon }\end{array}$ & $\begin{array}{l}\text { Intergenic } \\
\text { nucleotides }\end{array}$ \\
\hline Cox3 & $\mathrm{H}$ & $1-778$ & incomplete & - & TAA & 15 \\
\hline tRNA-Lys & $\mathrm{H}$ & 794-859 & 66 & & & 1 \\
\hline tRNA-Ala & $\mathrm{H}$ & $861-928$ & 68 & & & 10 \\
\hline tRNA-Arg & $\mathrm{H}$ & $939-1007$ & 69 & & & 7 \\
\hline tRNA-Asn & $\mathrm{H}$ & $1015-1082$ & 68 & & & 18 \\
\hline tRNA-Ile & $\mathrm{H}$ & $1101-1168$ & 68 & & & 3 \\
\hline Nad3 & $\mathrm{H}$ & $1172-1525$ & 354 & ATG & TAA & -1 \\
\hline tRNA-Ser & $\mathrm{H}$ & $1525-1594$ & 70 & & & -1 \\
\hline Nad2 & $\mathrm{H}$ & $1594-2648$ & 1055 & ATG & $\mathrm{TA}$ & 0 \\
\hline Cox1 & $\mathrm{H}$ & 2649-4184 & 1536 & ATG & TAA & 30 \\
\hline Cox2 & $\mathrm{H}$ & $4215-4901$ & 687 & ATG & TAA & -2 \\
\hline tRNA-Asp & $\mathrm{H}$ & $4900-4968$ & 69 & & & 0 \\
\hline Atp8 & $\mathrm{H}$ & $4969-5127$ & 159 & ATG & TAA & 6 \\
\hline Atp6 & $\mathrm{H}$ & 5134-5829 & 696 & ATG & TAA & 41 \\
\hline tRNA-Met & $\mathrm{L}$ & $5871-5937$ & 67 & & & 1 \\
\hline tRNA-Tyr & $\mathrm{L}$ & 5939-6008 & 70 & & & 6 \\
\hline tRNA-Cys & $\mathrm{L}$ & $6015-6079$ & 65 & & & -2 \\
\hline tRNA-Trp & $\mathrm{L}$ & $6078-6143$ & 66 & & & -1 \\
\hline tRNA-Gln & $\mathrm{L}$ & 6143-6209 & 67 & & & -1 \\
\hline tRNA-Gly & $\mathrm{L}$ & $6209-6277$ & 69 & & & 14 \\
\hline tRNA-Glu & $\mathrm{L}$ & $6292-6356$ & 65 & & & 0 \\
\hline $12 \mathrm{~s}$ & $\mathrm{H}$ & $6357-7313$ & 957 & & & 0 \\
\hline tRNA-Val & $\mathrm{H}$ & 7314-7381 & 68 & & & 0 \\
\hline $16 \mathrm{~s}$ & $\mathrm{H}$ & 7382-8733 & 1352 & & & 0 \\
\hline tRNA-Leu & $\mathrm{H}$ & 8734-8802 & 69 & & & 3 \\
\hline tRNA-Leu & $\mathrm{H}$ & 8806-8876 & 71 & & & -1 \\
\hline Nad1 & $\mathrm{H}$ & $8876-9817$ & 942 & ATG & TAA & 6 \\
\hline tRNA-Pro & $\mathrm{H}$ & $9824-9890$ & 67 & & & 1 \\
\hline Nad6 & $\mathrm{H}$ & $9892-10392$ & 501 & ATG & TAA & 5 \\
\hline Cytb & $\mathrm{H}$ & 10398-11537 & 1140 & ATG & TAA & 9 \\
\hline tRNA-Ser & $\mathrm{H}$ & $11547-11611$ & 65 & & & -1 \\
\hline tRNA-Thr & $\mathrm{L}$ & $11611-11679$ & 69 & & & 20 \\
\hline Nad4L & $\mathrm{H}$ & 11700-11996 & 297 & ATG & TAG & 11 \\
\hline Nad4 & $\mathrm{H}$ & $12008-13363$ & 1356 & ATA & TAG & 66 \\
\hline \multicolumn{7}{|c|}{ missing tRNA-His } \\
\hline Nad5 & $\mathrm{H}$ & $13430-15057$ & 1628 & - & - & 0 \\
\hline tRNA-Phe & $\mathrm{H}$ & missing & - & & & - \\
\hline
\end{tabular}


Tritia tingitana partial mt genome

\begin{tabular}{|c|c|c|c|c|c|c|}
\hline Gene & Strand & Location & $\begin{array}{l}\text { Size } \\
\text { (bp) }\end{array}$ & $\begin{array}{l}\text { Start } \\
\text { Codon }\end{array}$ & $\begin{array}{l}\text { Stop } \\
\text { codon }\end{array}$ & $\begin{array}{l}\text { Intergenic } \\
\text { nucleotides }\end{array}$ \\
\hline Cox3 & $\mathrm{H}$ & $1-762$ & incomplete & - & TAA & 12 \\
\hline tRNA-Lys & $\mathrm{H}$ & $775-840$ & 66 & & & 0 \\
\hline tRNA-Ala & $\mathrm{H}$ & $841-910$ & 70 & & & 6 \\
\hline tRNA-Arg & $\mathrm{H}$ & $917-987$ & 71 & & & 8 \\
\hline tRNA-Asn & $\mathrm{H}$ & $996-1065$ & 70 & & & 18 \\
\hline tRNA-Ile & $\mathrm{H}$ & $1084-1151$ & 68 & & & 3 \\
\hline Nad3 & $\mathrm{H}$ & $1155-1508$ & 354 & ATG & TAA & 0 \\
\hline tRNA-Ser & $\mathrm{H}$ & $1509-1577$ & 69 & & & -1 \\
\hline $\mathrm{Nad} 2$ & $\mathrm{H}$ & $1577-2631$ & 1055 & ATG & $\mathrm{TA}$ & 0 \\
\hline Cox1 & $\mathrm{H}$ & $2632-4167$ & 1536 & ATG & & 28 \\
\hline Cox2 & $\mathrm{H}$ & 4196-4882 & 687 & & TAA & -2 \\
\hline tRNA-Asp & $\mathrm{H}$ & $4881-4949$ & 69 & & & 0 \\
\hline Atp8 & $\mathrm{H}$ & $4950-5108$ & 159 & ATG & TAA & 8 \\
\hline Atp6 & $\mathrm{H}$ & 5117-5812 & 696 & ATG & TAG & 46 \\
\hline tRNA-Met & $\mathrm{L}$ & 5859-5925 & 67 & & & 2 \\
\hline tRNA-Tyr & $\mathrm{L}$ & 5928-5998 & 71 & & & -1 \\
\hline tRNA-Cys & $\mathrm{L}$ & $5998-6061$ & 64 & & & -2 \\
\hline tRNA-Trp & $\mathrm{L}$ & $6060-6125$ & 66 & & & -1 \\
\hline tRNA-Gln & $\mathrm{L}$ & 6125-6191 & 67 & & & -1 \\
\hline tRNA-Gly & $\mathrm{L}$ & 6191-6259 & 69 & & & 11 \\
\hline tRNA-Glu & $\mathrm{L}$ & 6271-6335 & 65 & & & 0 \\
\hline $12 \mathrm{~s}$ & $\mathrm{H}$ & 6336-7298 & 963 & & & 0 \\
\hline tRNA-Val & $\mathrm{H}$ & 7299-7366 & 68 & & & 0 \\
\hline $16 s$ & & $7367-8725$ & 1359 & & & 0 \\
\hline tRNA-Leu & $\mathrm{H}$ & $8726-8796$ & 71 & & & 3 \\
\hline tRNA-Leu & $\mathrm{H}$ & 8797-8865 & 69 & & & 0 \\
\hline Nad1 & $\mathrm{H}$ & $8866-9807$ & 942 & ATG & TAA & 6 \\
\hline tRNA-Pro & $\mathrm{H}$ & $9814-9880$ & 67 & & & 1 \\
\hline Nad6 & $\mathrm{H}$ & 9882-10382 & 501 & ATG & TAA & 6 \\
\hline Cytb & $\mathrm{H}$ & 10389-11528 & 1140 & ATG & TAA & 10 \\
\hline tRNA-Ser & $\mathrm{H}$ & $11539-11603$ & 65 & & & 0 \\
\hline tRNA-Thr & $\mathrm{L}$ & $11604-11671$ & 68 & & & 19 \\
\hline Nad4L & $\mathrm{H}$ & 11691-11987 & 297 & ATG & TAG & 11 \\
\hline $\mathrm{Nad4}$ & $\mathrm{H}$ & $11999-13354$ & 1356 & ATA & TAG & -1 \\
\hline tRNA-His & $\mathrm{H}$ & 13354-13419 & 66 & & & 1 \\
\hline Nad5 & $\mathrm{H}$ & 13421-15142 & 1722 & ATG & TAG & 30 \\
\hline tRNA-Phe & $\mathrm{H}$ & missing & - & & & - \\
\hline
\end{tabular}


Anentome sp. 15,069 bp

\begin{tabular}{|c|c|c|c|c|c|c|}
\hline Gene & Strand & Lo1cation & $\begin{array}{l}\text { Size } \\
\text { (bp) }\end{array}$ & $\begin{array}{l}\text { Start } \\
\text { Codon }\end{array}$ & $\begin{array}{l}\text { Stop } \\
\text { codon }\end{array}$ & $\begin{array}{l}\text { Intergenic } \\
\text { nucleotides }\end{array}$ \\
\hline Cox3 & $\mathrm{H}$ & $1-766$ & incomplete & - & TAA & 4 \\
\hline tRNA-Lys & $\mathrm{H}$ & 771-838 & 68 & & & -1 \\
\hline tRNA-Ala & $\mathrm{H}$ & 838-904 & 67 & & & 0 \\
\hline tRNA-Arg & $\mathrm{H}$ & $905-973$ & 69 & & & 5 \\
\hline tRNA-Asn & $\mathrm{H}$ & $979-1047$ & 69 & & & 6 \\
\hline tRNA-Ile & $\mathrm{H}$ & $1054-1124$ & 71 & & & 1 \\
\hline Nad3 & $\mathrm{H}$ & $1126-1479$ & 354 & ATG & TAA & 10 \\
\hline tRNA-Ser & $\mathrm{H}$ & $1490-1559$ & 70 & & & -1 \\
\hline $\mathrm{Nad} 2$ & $\mathrm{H}$ & $1559-2613$ & 1055 & ATG & TA & 0 \\
\hline Cox1 & $\mathrm{H}$ & $2614-4149$ & 1536 & ATG & TAA & 15 \\
\hline Cox2 & $\mathrm{H}$ & $4165-4851$ & 687 & ATG & TAA & -2 \\
\hline tRNA-Asp & $\mathrm{H}$ & $4850-4917$ & 68 & & & 1 \\
\hline Atp8 & $\mathrm{H}$ & 4919-5077 & 159 & ATG & TAA & 2 \\
\hline Atp6 & $\mathrm{H}$ & $5080-5772$ & 693 & ATG & TAA & 31 \\
\hline tRNA-Met & $\mathrm{L}$ & 5804-5868 & 65 & & & 1 \\
\hline tRNA-Tyr & $\mathrm{L}$ & 5869-5934 & 66 & & & 5 \\
\hline tRNA-Cys & $\mathrm{L}$ & $5940-6003$ & 64 & & & 44 \\
\hline tRNA-Gln & $\mathrm{L}$ & $6048-6114$ & 67 & & & 0 \\
\hline tRNA-Trp & $\mathrm{L}$ & 6115-6180 & 66 & & & 2 \\
\hline tRNA-Gly & $\mathrm{L}$ & 6183-6251 & 69 & & & -2 \\
\hline tRNA-Glu & $\mathrm{L}$ & $6250-6315$ & 66 & & & 0 \\
\hline $12 \mathrm{~s}$ & $\mathrm{H}$ & 6316-7266 & 951 & & & 0 \\
\hline tRNA-Val & $\mathrm{H}$ & 7267-7336 & 70 & & & 0 \\
\hline $16 s$ & $\mathrm{H}$ & 7337-8671 & 1335 & & & 0 \\
\hline tRNA-Leu & $\mathrm{H}$ & $8672-8741$ & 70 & & & 3 \\
\hline tRNA-Leu & $\mathrm{H}$ & 8745-8815 & 71 & & & -1 \\
\hline Nad1 & $\mathrm{H}$ & $8815-9756$ & 942 & ATG & TAA & 5 \\
\hline tRNA-Pro & $\mathrm{H}$ & $9762-9828$ & 67 & & & 1 \\
\hline Nad6 & $\mathrm{H}$ & 9830-10333 & 504 & ATG & TAA & 27 \\
\hline Cytb & $\mathrm{H}$ & 10361-11500 & 1140 & ATG & TAA & -1 \\
\hline tRNA-Ser & $\mathrm{H}$ & $11500-11565$ & 66 & & & 21 \\
\hline Nad4L & $\mathrm{H}$ & 11587-11883 & 297 & ATG & TAG & 5 \\
\hline $\mathrm{Nad4}$ & $\mathrm{H}$ & 11889-13244 & 1356 & TTA & TAA & -1 \\
\hline tRNA-His & $\mathrm{H}$ & 13244-13309 & 66 & & & 0 \\
\hline Nad5 & $\mathrm{H}$ & $13310-15022$ & 1713 & ATG & TAA & 47 \\
\hline tRNA-Phe & $\mathrm{H}$ & missing & - & & & - \\
\hline
\end{tabular}


Table S4 Pairwise uncorrected sequence divergence within Tritia.

\begin{tabular}{|c|c|c|c|c|c|c|c|c|c|c|c|c|c|c|c|c|c|c|c|c|c|c|}
\hline & 1 & 2 & 3 & 4 & 5 & 6 & 7 & 8 & 9 & 10 & 11 & 12 & 13 & 14 & 15 & 16 & 17 & 18 & 19 & 20 & 21 & 22 \\
\hline 1 T. neritea & & & & & & & & & & & & & & & & & & & & & & \\
\hline 2 T. pellucida & 0.023 & & & & & & & & & & & & & & & & & & & & & \\
\hline 3 T. grana & 0.129 & 0.128 & & & & & & & & & & & & & & & & & & & & \\
\hline 4 T. pfeifferi & 0.139 & 0.138 & 0.152 & & & & & & & & & & & & & & & & & & & \\
\hline 5 T. mutabilis & 0.128 & 0.128 & 0.143 & 0.143 & & & & & & & & & & & & & & & & & & \\
\hline 6 T. pallaryana & 0.143 & 0.140 & 0.148 & 0.153 & 0.150 & & & & & & & & & & & & & & & & & \\
\hline 7 T. corniculum & 0.143 & 0.140 & 0.149 & 0.154 & 0.151 & 0.006 & & & & & & & & & & & & & & & & \\
\hline 8 T. elongata & 0.146 & 0.146 & 0.153 & 0.155 & 0.150 & 0.108 & 0.109 & & & & & & & & & & & & & & & \\
\hline 9 T. incrassata-Spain & 0.171 & 0.172 & 0.179 & 0.183 & 0.174 & 0.185 & 0.185 & 0.184 & & & & & & & & & & & & & & \\
\hline 10 T. incrassata-Norway & 0.168 & 0.169 & 0.177 & 0.181 & 0.173 & 0.183 & 0.182 & 0.183 & 0.038 & & & & & & & & & & & & & \\
\hline $11 T$. varicosa & 0.190 & 0.190 & 0.195 & 0.196 & 0.189 & 0.199 & 0.198 & 0.195 & 0.186 & 0.183 & & & & & & & & & & & & \\
\hline 12 T. cuvierii & 0.151 & 0.150 & 0.164 & 0.167 & 0.158 & 0.163 & 0.163 & 0.166 & 0.184 & 0.179 & 0.199 & & & & & & & & & & & \\
\hline 13 T. tenuicosta & 0.148 & 0.150 & 0.160 & 0.165 & 0.157 & 0.166 & 0.167 & 0.168 & 0.177 & 0.173 & 0.198 & 0.125 & & & & & & & & & & \\
\hline 14 T. unifasciata & 0.162 & 0.161 & 0.173 & 0.173 & 0.168 & 0.176 & 0.176 & 0.176 & 0.185 & 0.185 & 0.192 & 0.139 & 0.139 & & & & & & & & & \\
\hline 15 T. reticulata & 0.152 & 0.151 & 0.161 & 0.165 & 0.149 & 0.163 & 0.165 & 0.162 & 0.170 & 0.168 & 0.187 & 0.135 & 0.133 & 0.138 & & & & & & & & \\
\hline 16 T. nitida & 0.156 & 0.154 & 0.162 & 0.169 & 0.152 & 0.164 & 0.166 & 0.169 & 0.171 & 0.168 & 0.189 & 0.133 & 0.136 & 0.141 & 0.106 & & & & & & & \\
\hline 17 T. denticulata & 0.132 & 0.130 & 0.147 & 0.146 & 0.136 & 0.143 & 0.143 & 0.149 & 0.164 & 0.163 & 0.179 & 0.135 & 0.135 & 0.149 & 0.135 & 0.136 & & & & & & \\
\hline 18 T. ovoidea & 0.136 & 0.133 & 0.144 & 0.150 & 0.134 & 0.148 & 0.148 & 0.155 & 0.161 & 0.160 & 0.187 & 0.142 & 0.141 & 0.154 & 0.139 & 0.139 & 0.120 & & & & & \\
\hline 19 T. tingitana & 0.146 & 0.146 & 0.159 & 0.156 & 0.152 & 0.157 & 0.157 & 0.163 & 0.176 & 0.173 & 0.192 & 0.135 & 0.137 & 0.151 & 0.129 & 0.133 & 0.130 & 0.138 & & & & \\
\hline 20 T. ephamilla & 0.130 & 0.129 & 0.143 & 0.148 & 0.132 & 0.141 & 0.142 & 0.149 & 0.159 & 0.158 & 0.184 & 0.144 & 0.142 & 0.151 & 0.133 & 0.137 & 0.110 & 0.116 & 0.134 & & & \\
\hline 21 T. elata & 0.129 & 0.127 & 0.139 & 0.140 & 0.129 & 0.141 & 0.141 & 0.150 & 0.160 & 0.157 & 0.181 & 0.137 & 0.139 & 0.149 & 0.133 & 0.136 & 0.113 & 0.073 & 0.131 & 0.110 & & \\
\hline 22 I. obsoleta & 0.146 & 0.144 & 0.156 & 0.159 & 0.151 & 0.163 & 0.162 & 0.165 & 0.173 & 0.173 & 0.188 & 0.158 & 0.159 & 0.170 & 0.154 & 0.157 & 0.138 & 0.139 & 0.151 & 0.134 & 0.135 & \\
\hline 23 T. vaucheri & 0.160 & 0.159 & 0.166 & 0.171 & 0.162 & 0.174 & 0.174 & 0.177 & 0.186 & 0.184 & 0.203 & 0.175 & 0.175 & 0.183 & 0.173 & 0.172 & 0.158 & 0.160 & 0.166 & 0.159 & 0.155 & 0.166 \\
\hline
\end{tabular}




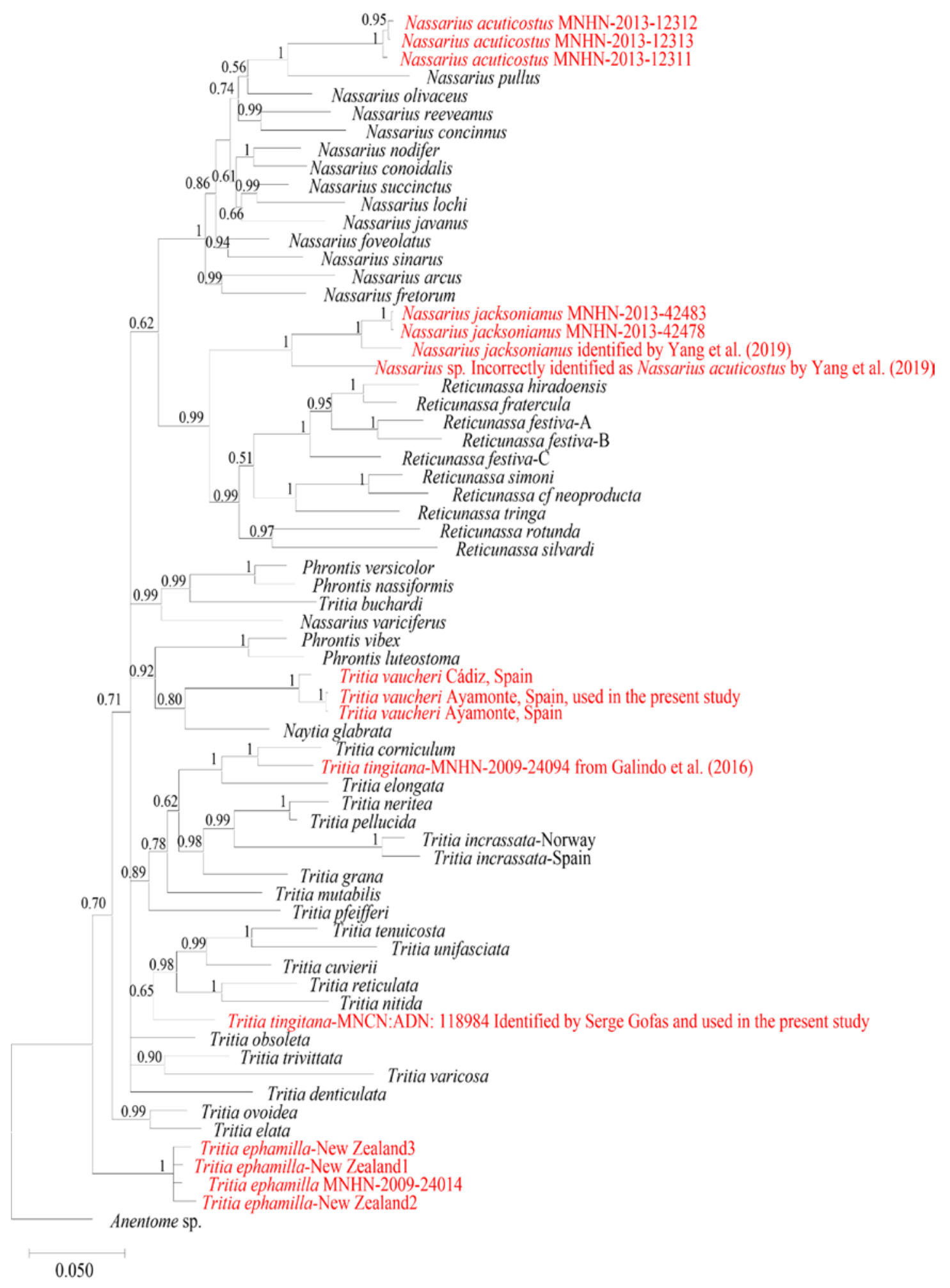

Figure S1. Phylogenetic relationships within Nassarrinae with Anentome sp. as outgroup based on the nucleotide sequences of cox1 fragments. Numbers at nodes are statistical support values for BI (posterior probabilities). For species in red, several specimens were seqeunced to ensure their correct identification. 